\title{
EFEITOS DA INOCULAÇÃO MICROBIANA DA SILAGEM PRÉ-SECADA DE ALFAFA SOBRE A FERMENTAÇÃO NO SILO, DIGESTIBILIDADE E DESEMPENHO PRODUTIVO DE VACAS LEITEIRAS
}

Dissertação apresentada para obtenção do título de Mestre, junto à Faculdade de Medicina Veterinária e Zootecnia da Universidade de São Paulo.

Departamento:

Nutrição e Produção Animal

Área de concentração:

Nutrição Animal

Orientador:

Prof. Dr. Paulo Henrique Mazza Rodrigues

PIRASSUNUNGA - SP 


\title{
EFEITOS DA INOCULAÇÃO MICROBIANA DA SILAGEM PRÉ-SECADA DE ALFAFA SOBRE A FERMENTAÇÃO \\ NO SILO, DIGESTIBILIDADE E DESEMPENHO PRODUTIVO DE VACAS LEITEIRAS
}

\begin{abstract}
Dissertação apresentada para obtenção do título de Mestre, junto à Faculdade de Medicina Veterinária e Zootecnia da Universidade de São Paulo.
\end{abstract}

\section{Departamento:}

Nutrição e Produção Animal

Área de concentração:

Nutrição Animal

Orientador:

Prof. Dr. Paulo Henrique Mazza Rodrigues 


\section{DADOS INTERNACIONAIS DE CATALOGAÇÃO-NA-PUBLICAÇÃO}

(Biblioteca da Faculdade de Medicina Veterinária e Zootecnia da Universidade de São Paulo)

T.1151 Magalhães, Vanessa Jaime de Almeida

FMVZ Efeitos da inoculação microbiana da silagem pré-secada de alfafa sobre a fermentação no silo, digestibilidade e desempenho produtivo de vacas leiteiras / Vanessa Jaime de Almeida Magalhães.

106 f. : il.

Dissertação (mestrado em Nutrição Animal) -

Universidade de São Paulo. Faculdade de Medicina Veterinária e Zootecnia. Departamento de Nutrição e Produção Animal, Pirassununga, 2002.

Área de concentração: Nutrição Animal.

Orientador: Prof. Dr. Paulo Henrique Mazza Rodrigues.

Unitermos: 1.Alfafa. 2.Silagem. 3.Inoculação. 4.Bactérias láticas.

5.Bovinocultura leiteira. 6.Leite (produção).

7.Digestibilidade. 
FOLHA DE APROVAÇÃO

Vanessa Jaime de Almeida Magalhães

Nutrição de ruminantes

Dissertação apresentada à Faculdade de Medicina Veterinária e Zootecnia da Universidade de São Paulo para obtenção do título de Mestre em Nutrição Animal.

Aprovado em 29/11/2002

\section{BANCA EXAMINADORA}

Assinatura:

Prof. Dr. Paulo Henrique Mazza Rodrigues

Julgamento:

Universidade de São Paulo

Assinatura:

Prof. Dr. Marcos Veiga dos Santos

Julgamento:

Universidade de São Paulo

Assinatura:

Prof. Dr. Paulo Roberto Leme

Julgamento:

Universidade de São Paulo 
"Os poucos professores que me impressionaram, não foram os que sabiam mais, mas aqueles que deram o máximo de sí, que me otharam de frente, tal como ewera, com um humanismo que despertow e atrain meu espirito inseguro e me chamow a assumir minha existência com minhas próprias mãos". 
Aos meus pais, Marco Antônio e Marinur, pelo amor, incentivo e apoio; por mais esta conquista e por acreditarem em mim, minha eterna gratidão.

Aos meus irmãos, Marco Antônio (Mineiro) e Heloise, pelo carinho, amizade e bons momentos.

Dedico. 
Aos meus avós, Milton e Maria de Lourdes; Roque (in memorian) e Joana, por serem exemplos de vida, força, coragem, união e amor. Espelhos de dignidade e perseverança.

Aos meus tios, tias, primos e primas, pela atenção, carinho e "adoção", principalmente, nestes anos de mestrado. A oportunidade de estarmos mais perto, trouxe-me mais alegrias.

Dedico. 
Ao Nelson C. Farias Júnior, pelo amor, carinho, dedicação, paciência e grande respeito aos meus ideais. Por incentivar e participar de todos os momentos desta jornada.

Ofereço. 
Ao Prof. Dr. Paulo H. Mazza Rodrigues, pela criteriosa orientação, dedicação, ensinamentos, amizade e, principalmente, confiança em mim depositada durante a execução deste trabalho.

Agradeço. 


\section{AGRADECIMENTOS}

A Deus por me permitir o dom da vida.

Aos professores do Departamento de Nutrição e Produção Animal da FMVZ/USP, pelo apoio, contribuição e oportunidade de cursar a Pós-Graduação.

Ao Prof. Dr. Félix Ribeiro de Lima, pela amizade e oportunidade de participação no Programa de Apoio ao Ensino (PAE).

Aos colegas do curso de Pós-Graduação, Adriana (Fofa), Alexandre (Xande), Ana Lúcia, Bianca, Carla, Fernanda Monteiro, Fernanda (Xeila), Luciana, Paula, Plínio, Rony, Sílvio Ramos, Tatiana e, em especial, ao Alexandre (Coca), Andrezza, Mayra, Sílvio Manginelli e Volnei, pela amizade, companheirismo, bons momentos e colaboração no desenvolvimento deste trabalho.

Aos funcionários do Departamento de Nutrição e Produção Animal da FMVZ/USP, em especial, à Alessandra, Cristiane, Isabel (Bel), Júnior, Lourdes e Lúcia, pela atenção, disponibilidade, amizade e paciência.

À Prefeitura do Campus Administrativo de Pirassununga, particularmente ao Gado de Leite, pela concessão dos animais e, à Fábrica de Ração, pela facilidade com a mistura de concentrados.

Ao Doutor Jorge Gonçalves da Fazenda Campestre, pela confecção das silagens.

Ao Everson e Gilmar, pela grande ajuda prestada, com eficiência e profissionalismo, durante todo período experimental.

Aos estagiários Gustavo e Heidge (Jaspion), pela grande ajuda no período experimental.

Aos técnicos Ari, Gilson, Lucinéia e Simi, pela atenção e ajuda com as análises laboratoriais.

Ao Laboratório Clínica do Leite do Departamento de Produção Animal da ESALQ/USP, pelo auxílio na realização das análises de leite.

Aos funcionários da Biblioteca, pelo auxílio e boa vontade em nos atender. 
Aos amigos Arlindo (Minhoca), Éder (Zé), Laura, Luiz, Marcia (Foférrima), Marcia Freiria, Nedilse, Otaviano (Joca), Roberta (Robs), Rosane (Baiana), Sandro, Tatiana (Patinha) e Weber, pelo grande incentivo, solidariedade, momentos de descontração e apoio nas horas difíceis. Cada um sabe o quão importante foi, e ainda é, para mim.

À Fundação de Amparo à Pesquisa do Estado de São Paulo (FAPESP) pelo auxílio financeiro e concessão da bolsa de estudos.

A todos aqueles que, direta ou indiretamente, contribuíram para a realização deste trabalho. 


\section{RESUMO}

MAGALHÃES, V. J. A. Efeitos da inoculação microbiana da silagem pré-secada de alfafa sobre a fermentação no silo, digestibilidade e desempenho produtivo de vacas leiteiras. [Effects of microbial inoculation of alfalfa haylage on silo fermentation characteristics, digestibility and performance of lactating dairy cows]. 2002. $106 \mathrm{f}$. Dissertação (Mestrado em Nutrição Animal) - Faculdade de Medicina Veterinária e Zootecnia, Universidade de São Paulo.

Foram objetivos do presente estudo avaliar os efeitos do inoculante microbiano Silobac $^{\circledR}$ (L. plantarum, P. pentosaceus), na silagem pré-secada de alfafa, em 22 silos, sendo 11 destes submetidos ao tratamento com inoculante. A alfafa foi cortada quando em estádio do meio do florescimento e os silos confeccionados em fardos de aproximadamente $600 \mathrm{~kg}$ revestidos com película de PVC branca. Amostras foram coletadas logo após a abertura de cada silo para análise da composição bromatológica e perfil fermentativo. Avaliou-se também, os efeitos desta inoculação sobre o consumo de matéria seca, digestibilidade aparente, produção e composição do leite de doze vacas da raça Holandesa, multíparas, com $135 \pm 16,4$ dias de lactação, distribuídas em delineamento em reversão simples com seqüência balanceada ("cross-over") com dois períodos sucessivos. Os tratamentos corresponderam a silagem pré-secada de alfafa (50,0\% de MS e 16,5\% de PB) controle ou inoculada. Cada período experimental teve duração de 21 dias, sendo os 5 últimos dias destinados à coleta de dados. Nos resultados relativos à fermentação, o inoculante diminuiu o teor de $\mathrm{MS}$ (inoculada $=44,7$ vs. controle $=51,2 \%$, aumentou a concentração de ácido acético (2,35 vs. 0,89\% MS) e apresentou tendência em aumentar os teores de carboidratos solúveis $(2,97$ vs. $2,44 \%$ MS), em relação ao grupo controle. $\mathrm{O}$ inoculante também tendeu em diminuir o escore de bolor obtido à $10 \mathrm{~cm}$ de profundidade, mas não a $30 \mathrm{ou} 50 \mathrm{~cm}$. Não foram observados efeitos sobre os teores de PB (15,9 vs. 16,4\% MS), NIDA (11,2 vs. $11,6 \%$ do $\mathrm{N}$ total), FDN (47,1 vs. 46,7\% MS), FDA (40,2 vs. 39,8\% MS), LDA (10,4 vs. $11,1 \% \mathrm{MS})$ e amido (0,82 vs. $0,69 \% \mathrm{MS})$, DIVMS (61,6 vs. $62,5 \% \mathrm{MS})$, poder tampão (52,9 vs. 51,7 meq./100g MS), as concentrações de etanol (0,018 vs. 0,024\% MS) e dos ácidos propiônico ( 0,00 vs. $0,00 \% \mathrm{MS})$, butírico (0,00 vs. $0,00 \% \mathrm{MS})$ e lático (5,62 vs. $4,45 \% \mathrm{MS})$, bem como sobre o $\mathrm{pH}$ (4,96 vs. 5,33), sobre as concentrações de $\mathrm{N}^{-\mathrm{NH}_{3}}$ 
(8,19 vs. 5,21\% do $\mathrm{N}$ total) ou sobre a estabilidade aeróbia. Quanto a digestibilidade, o inoculante aumentou a digestibilidade aparente da MS (81,7 vs. 74,2\%), PB (83,1 vs. $74,6 \%)$, EE (90,1 vs. 81,7\%), ENN (84,1 vs. 78,7\%), FB (74,8 vs. 61,9\%), FDN (70,0 vs. $58,0 \%)$, FDA (75,2 vs. $63,9 \%)$, amido (92,7 vs. $88,9 \%)$, EB (82,4 vs. $74,7 \%)$ e o NDT ( 80,5 vs. $73,3 \%$ ), em relação ao grupo controle. Porém, não houve efeito do inoculante sobre o consumo MS digestível (14,5 vs. 13,3 kg/animal/dia, ou 2,67 vs. $2,46 \%$ do PV) ou de NDT (14,3 vs. 13,2 kg/animal/dia ou 2,63 vs. 2,43\% do PV). Também não se observou efeito da inoculação sobre o CMS (17,8 vs. 17,8 $\mathrm{kg} / \mathrm{animal} /$ dia $)$, produção de leite $(23,0$ vs. $22,4 \mathrm{~kg} /$ dia $)$, porcentagem de gordura $(3,46$ vs. $3,47 \%$ ), proteína (2,96 vs. $2,93 \%)$, lactose (4,64 vs. $4,67 \%)$, sólidos totais $(11,9$ vs. $11,9 \%$ ) e sólidos desengordurados (8,49 vs. 8,48\%), nos resultados obtidos com as análises de leite.

Palavras-chave: alfafa, bactérias láticas, bovinocultura leiteira, digestibilidade, inoculação, produção de leite, silagem 


\begin{abstract}
MAGALHÃES, V. J. A. Effects of microbial inoculation of alfalfa haylage on silo fermentation characteristics, digestibility and performance of lactating dairy cows. [Efeitos da inoculação microbiana da silagem pré-secada de alfafa sobre a fermentação no silo, digestibilidade e desempenho produtivo de vacas leiteiras]. 2002. $106 \mathrm{f}$. Dissertação (Mestrado em Nutrição Animal) - Faculdade de Medicina Veterinária e Zootecnia, Universidade de São Paulo.
\end{abstract}

The objective of this study was to evaluate the effects of microbial inoculant Silobac ${ }^{\circledR}$ (L. plantarum, P. pentosaceus) on twenty-two big bales of alfalfa haylage, eleven treated with inoculant. Alfalfa crop was harvested at middle bloom stage and conditioned in bales about $600 \mathrm{~kg}$ capacity and covered with white tube plastic film. Silage was sampled to proceed chemical analyses after each silo was opened. Also was evaluated the effects of this inoculant on dry matter intake, apparent digestibility, milk yield and composition in twelve Holstein cows, at $135 \pm 16.4$ days in milk. A cross-over design with two periods of sampling was used. Treatments were alfalfa haylage $(50.0 \%$ $\mathrm{DM}$ and $16.5 \% \mathrm{CP}$ ) control or inoculated. Each experimental period extended for twenty-one days, the last five used for data collection. On chemical composition results, inoculation decreased DM content (inoculated $=44.7$ vs. control $=51.3 \%$ ), increased acetic acid content (2.35 vs. $0.89 \% \mathrm{DM})$ and tended to increase WSC content (2.97 vs. $2.44 \% \mathrm{DM}$ ) compared to control. It also tended to decrease mould on depth $10 \mathrm{~cm}$, but not on depth 30 or $50 \mathrm{~cm}$. Treatments did not influence CP (15.9 vs. 16.4\% DM), ADIN (11.2 vs. $11.6 \%$ of total $\mathrm{N}$ ), NDF (47.1 vs. $46.7 \% \mathrm{DM})$, ADF (40.2 vs. $39.8 \% \mathrm{DM}$ ), ADL (10.4 vs. $11.1 \%$ DM) and starch contents (0.82 vs. $0.69 \%$ DM), IVDMD (61.6 vs. $62.5 \%$ DM), buffering capacity (52.9 vs. 51.7 meq./100g DM), ethylic alcohol (0.018 vs. $0.024 \% \mathrm{DM})$, propionic (0.00 vs. $0.00 \% \mathrm{DM})$, butyric $(0.00$ vs. $0.00 \% \mathrm{DM})$ and lactic acids contents (5.62 vs. $4.45 \% \mathrm{DM}), \mathrm{pH}(4.96$ vs. 5.33$), \mathrm{NH}_{3}-\mathrm{N}$ content ( 8.19 vs. $5.21 \%$ of total $\mathrm{N}$ ) or aerobic stability. As for digestibility, the inoculation increased apparent digestibility of DM (81.7 vs. $74.2 \%)$, CP (83.1 vs. $74.6 \%)$, EE (90.1 vs. 81.7\%), NFE (84.1 vs. 78.7\%), CF (74.8 vs. 61.9\%), NDF (70.0 vs. 58.0\%), ADF (75.2 vs. $63.9 \%)$, starch (92.7 vs. $88.9 \%)$, GE (82.4 vs. $74.7 \%)$ and TDN (80.5 vs. $73.3 \%)$ compared to control. However, it did not influence digestible DMI (14.5 vs. 13.3 
$\mathrm{kg} / \mathrm{animal} /$ day or 2.67 vs. $2.46 \%$ of BW), nor TDN (14.3 vs. $13.2 \mathrm{~kg} /$ animal/day or 2.63 vs. $2.43 \%$ of BW). The inoculation did not also influence DMI (17.8 vs. 17.8 $\mathrm{kg} / \mathrm{animal} /$ day), milk yield (23.0 vs. $22.4 \mathrm{~kg} /$ day), fat (3.46 vs. 3.47\%), protein (2.96 vs. $2.93 \%)$, lactose (4.64 vs. 4.67\%), total solids (11.9 vs. $11.9 \%)$ and fat free solids percentage ( 8.49 vs. $8.48 \%$ ), on milk analysis results.

Keywords: alfalfa, dairy cattle, digestibility, inoculation, lactic acid bacteria, milk yield, silage 


\section{LISTA DE FIGURAS}

\section{CAPÍTULO III}

Página

Figura 01 - Composição bromatológica das silagens pré-secadas de alfafa controle e inoculada

058

Figura 02 - Porcentagem de ácidos orgânicos nas silagens pré-secadas de alfafa controle e inoculada

063

Figura 03 - Escore de bolor das silagens pré-secadas de alfafa controle e inoculada nas profundidades de $10 \mathrm{~cm}, 30 \mathrm{~cm}$ e $50 \mathrm{~cm}$

\section{CAPÍTULO IV}

Figura 01 - Digestibilidade aparente da MS da dieta e suas frações obtidas com silagens pré-secadas de alfafa controle e inoculada

\section{CAPÍTULO V}

Figura 01 - Produção de leite e de seus componentes por vacas alimentadas com silagens pré-secadas de alfafa controle ou inoculada

Figura 02 - Composição do leite de vacas alimentadas com silagens présecadas de alfafa controle ou inoculada 


\section{LISTA DE TABELAS}

\section{CAPÍTULO III}

Página

Tabela 01 - Composição bromatológica das silagens pré-secadas de alfafa submetidas ou não à aplicação de inoculante.

058

Tabela 02 - Fermentação das silagens pré-secadas de alfafa submetidas ou não à aplicação de inoculante

Tabela 03 - Estabilidade aeróbia das silagens pré-secadas de alfafa submetidas ou não à aplicação de inoculante

Tabela 04 - Escore de bolor das silagens pré-secadas de alfafa submetidas ou não à aplicação de inoculante

066

\section{CAPÍTULO IV}

Tabela 01 - Composição bromatológica das silagens pré-secadas de alfafa controle e inoculada (porcentagem com base na MS)

076

Tabela 02 - Proporções de ingredientes utilizados e composição bromatológica das rações, com base na matéria seca.

Tabela 03 - Digestibilidade aparente da MS da dieta e suas frações obtidas com silagens pré-secadas de alfafa tratadas ou não com inoculante 
Tabela 04 - Consumo de matéria seca digestível e de NDT obtidos com silagens pré-secadas de alfafa tratadas ou não com inoculante.....

084

\section{CAPÍTULO V}

Tabela 01 - Composição bromatológica das silagens pré-secadas de alfafa controle e inoculada (porcentagem com base na MS)

092

Tabela 02 - Proporções de ingredientes utilizados e composição bromatológica das rações, com base na matéria seca.

093

Tabela 03 - Consumo de matéria seca obtido com silagens pré-secadas de alfafa submetidas ou não à aplicação de inoculante

Tabela 04 - Efeitos da inoculação microbiana na silagem pré-secada de alfafa sobre a produção e composição do leite

098

Tabela 05 - Efeitos da inoculação microbiana na silagem pré-secada de alfafa sobre a CCS, NUL e características físico-químicas do leite 


\section{LISTA DE ABREVIATURAS}

\begin{tabular}{|c|c|}
\hline $\mathrm{Ca}$ & - cálcio \\
\hline $\mathrm{CCS}$ & - contagem de células somáticas \\
\hline CIDA & - cinzas insolúveis em detergente ácido \\
\hline CMS & - consumo de matéria seca \\
\hline CMSD & - consumo de matéria seca digestível \\
\hline CMSDPV & - consumo de matéria seca digestível em função do peso vivo \\
\hline CMSPV & - consumo de matéria seca em função do peso vivo \\
\hline $\mathrm{CMSPV}^{0,75}$ & - consumo de matéria seca, em gramas, por $\mathrm{kg}$ de peso vivo metabólico \\
\hline CNDT & - consumo de nutrientes digestíveis totais \\
\hline CNDTPV & - consumo de nutrientes digestíveis totais em função do peso vivo \\
\hline $\mathrm{CV}$ & - coeficiente de variação \\
\hline DIVMS & - digestibilidade in vitro da matéria seca \\
\hline EB & - energia bruta \\
\hline $\mathrm{EE}$ & - extrato etéreo \\
\hline ENN & - extrativo não nitrogenado \\
\hline FB & - fibra bruta \\
\hline FDA & - fibra em detergente ácido \\
\hline FDN & - fibra em detergente neutro \\
\hline LCG $4,0 \%$ & - produção de leite corrigida para $4 \%$ de gordura \\
\hline LDA & - lignina em detergente ácido \\
\hline MM & - matéria mineral \\
\hline MS & - matéria seca \\
\hline
\end{tabular}




$\begin{array}{ll}\mathrm{N}_{3} \mathrm{NH}_{3} & \text { - nitrogênio amoniacal } \\ \text { NDT } & \text { - nutrientes digestíveis totais } \\ \text { NIDA } & \text { - nitrogênio insolúvel em detergente ácido } \\ \text { NIDN } & \text { - nitrogênio insolúvel em detergente neutro } \\ \text { NNP } & \text { - nitrogênio não protéico } \\ \text { NS } & \text { - não significativo } \\ \text { NUL } & \text { - nitrogênio uréico no leite } \\ \text { P } & \text { - fósforo } \\ \text { PB } & \text { - proteína bruta } \\ \text { PT } & \text { - poder tampão } \\ \text { PV } & \text { - peso vivo } \\ \text { PV } & \text { - peso vivo metabólico } \\ \text { vs. } & \text { - versus }\end{array}$




\section{SUMÁRIO}

Página

CAPÍTULO I - INTRODUÇÃO .................................................................... 020

CAPÍTULO II - REVISÃO DE LITERATURA ................................................ 022

1 - Fatores que afetam a qualidade da silagem......................................... 022

2 - Os inoculantes como aditivo …….......................................................... 027

3 - Cultura de alfafa para a produção de silagem inoculada.......................... 030

4 - Referências bibliográficas ................................................................... 041

CAPÍTULO III - EFEITOS DA ADIÇÃO DE INOCULANTE MICROBIANO

SOBRE A COMPOSIÇÃO BROMATOLÓGICA, FERMENTAÇÃO E ESTABILIDADE AERÓBIA DA SILAGEM PRÉ-SECADA DE ALFAFA........ 048

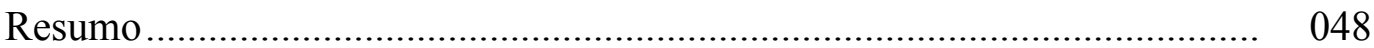

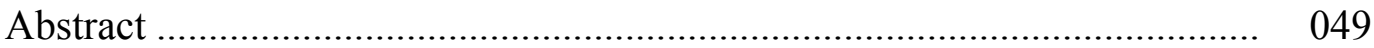

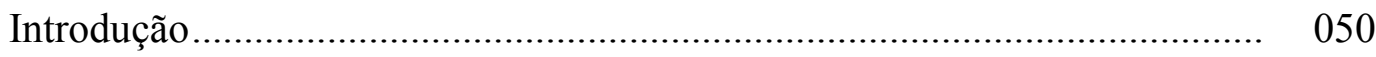

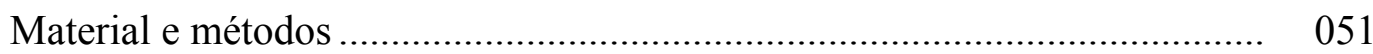

Resultados e discussão .................................................................. 053

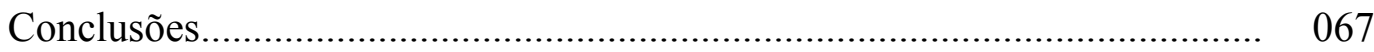

Referências bibliográficas .................................................................. 068 
CAPÍTULO IV - INOCULAÇÃO MICROBIANA DA SILAGEM PRÉSECADA DE ALFAFA SOBRE A DIGESTIBILIDADE APARENTE EM

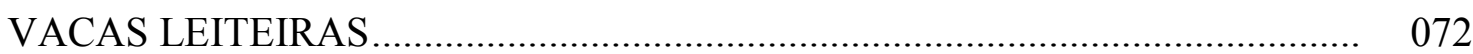

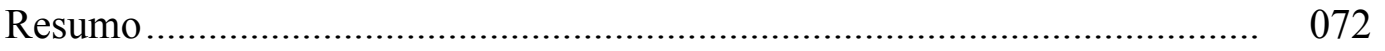

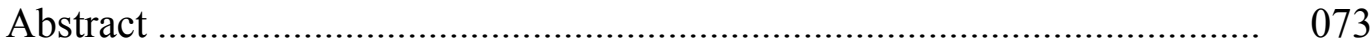

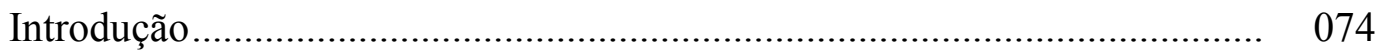

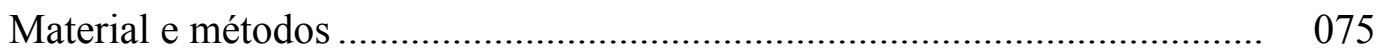

Resultados e discussão ........................................................................... 078

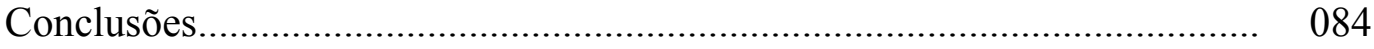

Referências bibliográficas ................................................................ 084

CAPÍTULO V - DESEMPENHO PRODUTIVO DE VACAS LEITEIRAS ALIMENTADAS COM SILAGEM PRÉ-SECADA DE ALFAFA ADICIONADA DE INOCULANTE MICROBIANO ….................................... 088

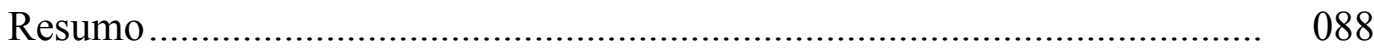

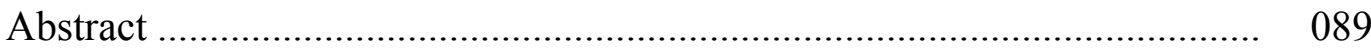

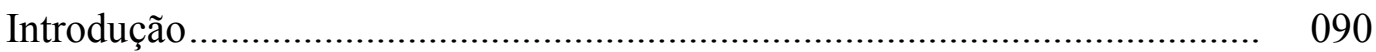

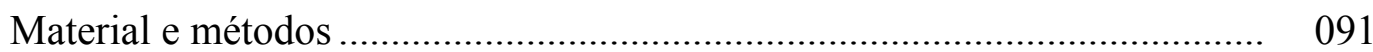

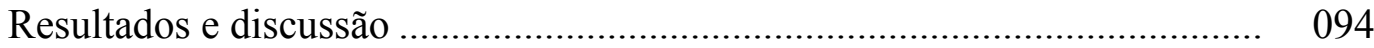

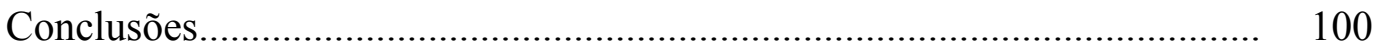

Referências bibliográficas ......................................................................... 101

CAPÍTULO VI - CONSIDERAÇÕES FINAIS ................................................. 105 


\section{CAPÍTULO I}

\section{INTRODUÇÃO}

É indiscutível a importância da silagem como uma das principais ferramentas para manutenção da produtividade animal no período das secas, sendo que, em sistemas totalmente confinados, essa forma de conservação ainda desempenha o papel de assegurar uma alimentação estável durante todo o ano. A despeito das inúmeras vantagens do processo de ensilagem, muitas são suas limitações quando o material empregado não é adequado, tal como são o milho e o sorgo. Como uma tentativa de contornar tais limitações inerentes à composição química da matéria prima (teor de matéria seca, carboidratos solúveis, poder tampão, nitratos e outras substâncias nitrogenadas), ao processamento (trituração, compactação, vedação, tempo de enchimento e de armazenamento, forma de descarregamento) e outros não controláveis (clima e população microbiana) é que se tem grande interesse no uso de aditivos químicos ou biológicos, que possam minimizar ou mesmo contornar tais fatores limitantes à plena conservação do valor nutritivo da forragem. Dentre os muitos aditivos disponíveis, o uso de inoculantes microbianos está extensamente difundido nos países desenvolvidos e vem despertando grande interesse dos produtores brasileiros. Entretanto, os resultados obtidos com sua utilização são contraditórios, já que melhoras no perfil fermentativo da silagem nem sempre são acompanhadas de melhoras do valor nutritivo e/ou ganhos no desempenho animal, sendo que o inverso também é verdadeiro. Esses fatores justificaram a investigação dos efeitos destes produtos em uma grande 
variedade de plantas forrageiras (milho, sorgo, girassol, capim elefante e alfafa) utilizadas para a confecção de silagem, seja sobre o aspecto fermentativo ou nutricional. Dados obtidos pelo presente grupo de pesquisa mostraram aumento do valor nutritivo unicamente da silagem de alfafa inoculada com culturas de Lactobacillus plantarum e Pediococcus pentosaceus, em detrimento das outras culturas. Tal fenômeno tem sido justificado pelo fato da planta de alfafa conter contagem de bactérias epfíticas 10 vezes menores que outras culturas, como o milho, por exemplo. A presença desse possível fator limitante durante a ensilagem da alfafa justifica a avaliação da utilização dessa poderosa ferramenta de manejo, que é a inoculação microbiana. 


\section{CAPÍTULO II}

\section{REVISÃO DE LITERATURA}

\section{1 - Fatores que afetam a qualidade da silagem}

O processo de ensilagem constitui um dos métodos mais seguros de garantir o alimento para o gado durante o inverno e secas prolongadas. Curtas estações de crescimento e a dificuldade nas condições de secagem a campo, durante a colheita, encorajaram os produtores a armazenar culturas com alto conteúdo de umidade na forma de silagens, apesar de que as perdas durante o armazenamento e descarregamento possam ser substanciais (WARDYNSKI et al., 1993). FOX (1976) e GOODRICH e MEISKE (1976) relataram que a quantidade de 5\% a $20 \%$ da matéria seca não era recuperada após o processo de ensilagem.

Segundo HENDERSON (1993), a conservação de forrageiras úmidas na forma de silagem é obtida a partir da fermentação anaeróbia, onde as bactérias transformam os açúcares da planta em ácidos orgânicos, compostos principalmente pelo lático e acético. Considera-se que a fermentação seja adequada quando ocorre o predomínio do ácido lático sobre os ácidos acético e butírico, já que o primeiro apresenta maior capacidade hidrogeniônica que os últimos. Além disso, níveis altos de ácido acético e butírico estão negativamente correlacionados com o consumo. A silagem de gramínea e leguminosa representa, na época da seca, cerca de 50 a $60 \%$ da alimentação total dos ruminantes na Europa, Reino Unido e Irlanda do Norte. No Brasil, apesar da silagem também 
representar o principal alimento conservado para utilização nas épocas de escassez, faltam dados mais precisos.

Para a produção de uma silagem de excelente qualidade é necessário manter as condições anaeróbias, restringindo a respiração da planta durante a colheita, e retardando o crescimento e o metabolismo oxidativo dos microrganismos (OHYAMA et al., 1975 e BARRY et al., 1980). Falhas em tais condições podem diminuir a recuperação de nutrientes, resultando na produção de alimentos volumosos de baixa qualidade, com reduções no seu consumo e conseqüente baixo desempenho animal (CLEALE et al., 1990), fatores, esses, motivados pela predominância de fermentação de bactérias indesejáveis, tais como Clostridium $s p$. e outras, responsáveis pelo desdobramento de açúcares, do ácido lático, proteólise e desaminação de aminoácidos com conseqüentes produções de ácido acético e butírico, nitrogênio amoniacal, amidas e aminas (WHITTENBURRY, 1968). Tais substâncias são responsáveis pela redução da qualidade do material fermentado e estão também correlacionadas aos aumentos nas perdas de matéria seca (SCHAEFER et al., 1989).

As bactérias ácido láticas presentes na forragem convertem o açúcar em ácido lático durante o processo de ensilagem; como resultado, o pH é reduzido, e a forragem é preservada (CAI et al., 1999a). Segundo MUCK (1988), o sucesso da fermentação ácido lática requer três elementos: meio anaeróbio, substrato adequado para as bactérias produtoras de ácido lático e uma população dessas bactérias em quantidade suficiente para que a fermentação ocorra. Assim, quatro fatores biológicos influenciam negativamente a qualidade da silagem: a respiração celular da planta, a atividade enzimática da planta, a atividade clostridiana e a atividade aeróbia microbiana, todos afetando o valor alimentar da silagem. Porém, os principais fatores responsáveis pela 
redução da qualidade da silagem são a presença de enzimas proteolíticas, clostrídios e microrganismos aeróbios. E os processos responsáveis pela perda de matéria seca e energia são: a respiração da planta, microrganismos aeróbios, perdas por descarboxilação de açúcares e os clostrídios.

Ainda assim, boas condições ambientais, substrato suficiente para as bactérias acido láticas, no caso da utilização de aditivos (HENDERSON, 1993), bom manejo, boa regulagem do maquinário destinado à colheita, garantia da manutenção do meio anaeróbio, tamanho certo das partículas a serem ensiladas (STOKES, 1992 e HARRISON et al., 1994), boa compactação para a efetiva e rápida expulsão do ar (WOOLFORD, 1990), ausência de rachaduras a fim de evitar a infiltração de ar ou de água, rápido fechamento do silo, cobertura do silo com lonas plásticas (MUCK, 1987) são mecanismos para minimizar as perdas de matéria seca, energia e qualidade da silagem. O manejo deve permitir a ocorrência e a manutenção do meio anaeróbio do silo, já que este é o ponto crítico da confecção de uma boa silagem (McDONALD et al., 1991).

O mais seguro e efetivo método de prevenção da deterioração aeróbia é a certeza de que a silagem será consumida no mesmo dia da sua remoção. As porções devem ser retiradas sem que haja interferência no restante do material que continuará ensilado. Tem-se visto que o uso de maquinário que não interfira na compactação da silagem, tem trazido resultados mais satisfatórios (McDONALD et al., 1991). A taxa de remoção ao longo do silo deve ser de 10 a $30 \mathrm{~cm}$ diários, sendo que esse valor deve ser maior no verão (WILKINSON e KILKENNY, 1977 e HONIG e WOOLFORD, 1980). A respeito disso, o modelo do silo é muito importante. Silos trincheira devem ser tão compridos 
quanto estreitos, para diminuir a superfície da área da silagem exposta ao ar e permitir a retirada do material em fatias mais largas (WOOLFORD, 1984).

O tratamento da forragem antes da ensilagem é fator muito importante que tem influências subseqüentes na estabilidade aeróbia da silagem. Secagem demorada, enchimento lento e problemas de fechamento do silo, são todos procedimentos que podem resultar em aumento da população de microrganismos aeróbios que vão permanecer dormentes até que o silo seja aberto. A infusão contínua de ar durante o armazenamento, tem efeito deteriorante por estimular a persistência dos microrganismos aeróbios (HONIG e WOOLFORD, 1980).

Quanto mais ácido lático for produzido em relação aos ácidos acético e butírico, menor é a energia despendida para a produção de calor, menores as perdas por descarboxilação, menor a formação de gases e mais agradável para os animais, quanto ao sabor e aroma, se torna a silagem.

O excesso de umidade presente implica em riscos de fermentações secundárias indesejáveis, já que a menor pressão osmótica favorece o desenvolvimento das bactérias do gênero Clostridium sp. (WILKINSON, 1983). Sabe-se que o teor de carboidratos solúveis das plantas, por ocasião da ensilagem, é um dos fatores fundamentais para que os processos fermentativos se desenvolvam de maneira eficiente. Tais açúcares constituem os substratos prontamente disponíveis para o desenvolvimento das bactérias láticas, o que os torna essenciais para a produção de níveis adequados de ácido lático e a conseqüente rápida redução do $\mathrm{pH}$, necessária para a inibição da atividade proteolítica das enzimas vegetais e do desenvolvimento das bactérias indesejáveis (MUCK, 1988).

Além dos teores de umidade e carboidratos solúveis, outro fator intrínseco à forrageira que interfere no processo fermentativo, é o poder tampão. Tampões são 
sistemas, cuja presença em um meio, torna-o resistente à variações nas concentrações hidrogeniônicas (McDONALD et al., 1991). O poder tampão das plantas não ensiladas é atribuído aos ácidos orgânicos e aos sais existentes nas forragens (McDONALD e HENDERSON, 1962), principalmente os ácidos málico, cítrico e fosfórico (WHITTENBURRY et al., 1967). A elevação do poder tampão das plantas após a ensilagem tem sido atribuída às modificações químicas que se processam no silo, como a formação de ácidos orgânicos, tal como o lático e acético (McDONALD e HENDERSON, 1962), e amônia (TOSI, 1973).

Em alguns casos, desconsiderando a ocorrência de fermentações secundárias, os clostrídios e outras bactérias não produtoras de ácido lático são dominantes. Fermentações resultantes destas bactérias ocasionam o aumento das perdas de matéria seca e diminuição da qualidade nutricional da silagem (SPECKMAN et al., 1981).

Após a abertura de um silo, observa-se a progressiva deterioração aeróbia, causada pela reativação da proliferação da microbiota que havia permanecido inativa sob as condições anaeróbias anteriores, caracterizada pelo aumento da temperatura e do pH, devido à oxidação dos produtos finais da fermentação. Tudo isso resulta em perdas de valor nutritivo, restringindo ou até rejeitando o consumo de matéria seca, causando distúrbios digestivos e, em casos extremos, ocasionando a morte do animal pela presença de toxinas (HATTORI et al., 1994).

O processo de ensilagem não é isento de riscos e as perdas podem ocorrer durante o emurchecimento, fermentação e descarregamento do material, podendo variar de 10 a 50\% da matéria seca ensilada (HENDERSON, 1993). Segundo McDONALD et al. (1991), as perdas de matéria seca podem chegar a mais de 15\%, quando as condições de fermentação não são as desejadas e o armazenamento não é satisfatório. 
Baseando nisso, é possível justificar a grande importância do uso de aditivos nas silagens de países de clima tropical, onde o valor esperado do material ensilado obtido a partir de forragens não é satisfatório, devido à sua alta umidade e à quantidade de carboidratos, além das perdas decorrentes de eventuais fatalidades (manejo, fatores climáticos, etc.) terem significado considerável na produtividade animal.

\section{2 - Os inoculantes como aditivo}

Os resultados obtidos com o uso dos vários aditivos existentes no mercado, quanto à preservação e fermentação da silagem, além de respostas no desempenho animal, vêm sendo extensivamente estudados ao longo da sua produção e utilização em todo o mundo (HARRISON et al., 1994). Estes trabalhos têm abrangido uma variedade de espécies forrageiras e aditivos, porém não têm sido amplos o suficiente para esclarecer as variações encontradas dentro de várias espécies, quando utilizados diferentes aditivos.

O ideal seria que os aditivos tivessem comprovada capacidade de reduzir as perdas de matéria seca, aumentar a qualidade higiênica, limitar fermentações secundárias, aumentar a estabilidade aeróbia (WARDYNSKI et al., 1993), incrementar o valor nutritivo da silagem e, finalmente, oferecer ao produtor ganhos financeiros consideráveis ao investimento inicial dessa tecnologia (HENDERSON, 1993).

De uma forma geral, os aditivos podem ser classificados como inibidores ou estimulantes da fermentação (McDONALD et al., 1991), sendo que outras características interferem nos resultados relativos à qualidade da silagem, como: fatores inibitórios da deterioração aeróbia, quantidade de nutrientes e capacidade absorvente do 
aditivo (MUCK, 1988). Segundo HARRISON et al. (1994), o tipo mais comum de aditivo utilizado nos Estados Unidos são os inoculantes microbianos (estimulantes da fermentação), sendo que outras formas de aditivos também são bastante comuns, como enzimas, ácidos (propiônico nos estados Unidos e fórmico na Europa) e fontes de nitrogênio não protéico (amônia e uréia).

Muitos estudos têm objetivado o desenvolvimento de técnicas para a rápida redução do pH durante a ensilagem. Uma das maneiras é a direta acidificação do meio com materiais como o ácido fórmico e o ácido sulfúrico (BARRY et al., 1980; HENDERSON e McDONALD, 1984 e HAIGH e PARKER, 1985). A adição de ácido fórmico restringe a fermentação dos açúcares liberados pela degradação da parede celular e dos açúcares já presentes na forragem, e estes efeitos são maiores na fermentação dos produtos da alfafa (NADEAU et al., 2000). Entretanto, seu uso é limitado devido a sua propriedade corrosiva, entre outras. Uma alternativa tem sido o desenvolvimento de culturas de bactérias produtoras de ácido lático, que são aplicadas na forragem durante a colheita (CLEALE et al., 1990).

Tudo deve ser feito para que as bactérias desejáveis entrem em ação o mais rápido possível, produzindo o ácido lático e inibindo a ação dos microrganismos indesejáveis. Vários aditivos vêm sendo propostos e usados na redução da deterioração aeróbia, uma vez que eles têm propriedades antimicrobianas contra a microbiota representada pelos fungos que se desenvolvem na silagem em presença de ar (MUCK, 1988).

Segundo HENDERSON (1993), silagens aditivadas têm sido utilizadas ao longo dos anos, com poucos riscos, para o aumento do seu valor nutritivo. Os efeitos sobre a fermentação, composição da silagem e desempenho animal, com o uso de aditivos, 
depende do tipo de inoculante usado, quantidade aplicada, sua atividade biológica, tipo da forragem, conteúdo de matéria seca e composição química da forragem (HARRISON et al., 1994).

Segundo WHITTENBURRY (1968), as espécies produtoras de ácido lático são representadas pelos gêneros lactobacilos e pediococos. A rápida produção do ácido lático causa a redução e a manutenção do baixo $\mathrm{pH}$, permitindo a adequada preservação do material ensilado e minimização das perdas de nutrientes pela inibição do crescimento de clostrídios e contribuindo, de forma significativa, para a microbiota fermentativa da silagem, por proporcionar a dominância final de bactérias produtoras de ácido lático (SPECKMAN et al., 1981).

Nos últimos 5 a 10 anos, considerável atenção foi direcionada para o emprego da celulase, hemicelulase e amilase como aditivos de silagens, pois sua função primária seria quebrar a parede celular (polissacarídeos) e o amido dos grãos, aumentando a fermentação da silagem e a utilização animal (CHEN et al., 1994).

A adição de enzimas inoculantes é a forma mais comum de aumentar o propósito de ruptura da parede celular da forragem, durante o processo de ensilagem. Os aditivos biológicos estimulam a ação dos lactobacilos, já que as forrageiras contém glicídios de fermentação imediata e outros da parede celular, representados por celulose e hemicelulose, que os lactobacilos não conseguem fermentar. As enzimas específicas que provocam hidrólise parcial dessa parte dos glicídios, aumentam a disponibilidade de açúcares para ação dos lactobacilos (McDONALD et al., 1991).

Assim a combinação de inoculante microbiano com celulase promove uma melhora na fermentação da silagem por aumentar a disponibilização de carboidratos solúveis. Entretanto, a adição de altas concentrações dessa enzima não promove 
resultados adicionais, uma vez que se observa acúmulo de açúcares. Já para a alfafa, que possui baixa concentração de açúcares, a melhora resultante da combinação é proporcionalmente maior (NADEAU et al., 2000).

Segundo KUNG et al. (1990); TENGERDY et al. (1991) e SHEPERD et al. (1995), a adição combinada de pectinase, celulase e hemicelulase favorece a degradação enzimática da parede celular das forragens durante o processo de ensilagem, o que favorece a disponibilização de substrato para a produção de ácido lático.

Quando uma silagem de gramínea, tratada com celulase, foi suplementada com fonte protéica, a eficiência da síntese de proteína microbiana ruminal e o fluxo microbiano duodenal foram aumentados, quando comparados com a silagem tratada com ácido fórmico e suplementada com as mesmas fontes protéicas. Estes índices constatam que a silagem tratada com enzimas e suplementada com uma fonte adicional de carbono e energia estimula o crescimento microbiano no rúmen (JACOBS e McALLAN, 1992). Da mesma forma que, quando uma silagem de cevada-ervilhaca (KUNG et al., 1990) e uma de trigo forrageiro (FROETSCHEL et al., 1991) foram ensiladas na presença de enzimas aditivadas, também foram observados aumento da fermentação ácido-lática e aumento da digestão da fibra.

\section{3 - Cultura de alfafa para a produção de silagem inoculada}

Nas suas diversas variedades, a alfafa constitui uma das espécies leguminosas mais cultivadas. É tratada como uma forrageira de grande interesse principalmente para o produtor, tanto pela quantidade de forragem que pode ser obtida por unidade de superfície cultivada, como pelo elevado valor nutritivo, riqueza em proteínas, vitaminas 
$\left(\mathrm{A}, \mathrm{B}_{1}, \mathrm{~B}_{2}, \mathrm{C}, \mathrm{E}\right.$ e $\left.\mathrm{K}\right)$ e substâncias minerais, tais como o cálcio e o fósforo. Sua qualidade biológica vai depender de muitos fatores e, por isso, pode sofrer grandes variações. Entre os fatores que a influenciam incluem-se a fertilidade do solo, o clima, a variedade cultivada, a fertilização, a fase de desenvolvimento da planta no momento do corte e os métodos de utilização ou conservação (JUSCAFRESA, 1982).

Sendo uma cultura milenar, possui uma gama muito extensa de variações genéticas, reflexo das grandes diferenças de ambientes regionais e humanos em que se têm produzido. Em todos os países que é cultivada, tem se obtido muitas variedades e cultivares especialmente adaptadas às condições de sua respectiva região de cultivo. No estado de São Paulo a alfafa não tem apresentado rendimentos satisfatórios, ficando estes para os estados mais ao sul do Brasil. No estado do Rio Grande do Sul foi selecionada uma variedade, a alfafa crioula, que tem se mostrado mais promissora, assim como a variedade moapa e europa. A alfafa crioula apresenta rápida recuperação após o corte, bons rendimentos de matéria seca, boa distribuição estacional e grande persistência. Em experimentos conduzidos na Estação Experimental de Lages (EMPASC), durante 9 anos, tem se observado que cerca de $70 \%$ da produção de matéria seca está concentrada durante o fim da primavera, verão e fins de outono e $30 \%$ no período frio, o que corresponde de 1,5 a 2,0 t/ha/ano de feno de alta qualidade (NUERNBERG, 1986). ALCÂNTARA (1988) cita que na região de Missões (RS) realizaram-se 9 cortes no primeiro ano, apresentando rendimentos superiores a 10 ton./ha de feno. Em condições ideais de clima e irrigação, a cultura pode chegar a fornecer 5 a 8 cortes/ano. O critério mais indicado para definir o melhor momento para utilização da alfafa em sistemas de cortes é aquele que considera o florescimento e/ou o desenvolvimento das brotações basais. Assim, é no aparecimento das primeiras flores 
( $10 \%$ de florescimento) ou quando as brotações basais atingirem uma altura de 2 a $3 \mathrm{~cm}$ que se deve fazer o corte. Nesse estádio de desenvolvimento da planta ocorrem as maiores produções de forragens associadas a elevados teores de proteína. A partir desse estádio, em razão do aumento de incidência de doenças foliares (principalmente nos meses mais quentes do ano), observa-se uma queda de folhas, refletindo negativamente, tanto na produtividade como na qualidade da forragem produzida. A alfafa crioula, cultivada há muito tempo, possui muito mais resistência às nossas condições climáticas que as importadas, mostrando superioridade em competição. Seu feno, tão utilizado, contém $14,8 \%$ em proteína bruta, valor este superior aos trevos e outras leguminosas. A alfafa é um alimento completo para qualquer idade animal, tanto para animais de cria como para de engorda. Nos países de pecuária adiantada, além do feno, é utilizada na forma de farinha. É bastante palatável, digestível e apreciada por grande número de espécies animais, quer seja consumida verde, farinada ou, ainda, como feno e silagem (ARAÚJO, 1978).

A conservação da alfafa vem se tornando bastante popular na forma ensilada, principalmente por causa do seu alto rendimento de matéria seca e conteúdo de proteína bruta (BROUK e BELYEA, 1993). Segundo BOLSEN et al. (1989), a alfafa e o milho são as duas culturas mais utilizadas na produção de silagem nos Estados Unidos e no Canadá. Entretanto, comparando as duas forrageiras, a alfafa freqüentemente apresenta maiores dificuldades no processo de ensilagem. Segundo McDONALD et al. (1991), forrageiras que, como a alfafa, possuem um alto teor protéico, baixo teor de carboidratos solúveis e alto poder tampão são menos aptas à sofrerem uma boa fermentação e com isso sofrerem maior proteólise durante o processo de ensilagem que, segundo POLAN et al. (1998), mesmo com um desenvolvimento rápido e completo das 
condições anaeróbias, as atividades bacterianas e enzimáticas podem causar uma considerável proteólise. A adição de aditivos que reduzam o $\mathrm{pH}$ podem reduzir a proteólise e auxiliar na preservação da proteína.

A microbiota natural, microrganismos que estão presentes naturalmente nas forrageiras, é responsável pela fermentação da silagem e também influencia a eficiência da inoculação microbiana. Tal microbiota é constituída basicamente de bactérias homofermentativas (pediococos, streptococos e algumas espécies de lactobacilos) benéficas para o processo de ensilagem, heterofermentativas (enterobactérias), leveduras e fungos, além de esporos de clostrídios, indesejáveis para o processo fermentativo (McDONALD et al., 1991). Normalmente o número de bactérias láticas naturais é baixo nas forragens (SPECKMAN et al., 1981; WOOLFORD, 1984 e MUCK, 1989) e, no processo de ensilagem, o predomínio inicial normalmente é de bactérias heterofermentativas (LINDGREN et al., 1983).

Geralmente, a alfafa possui baixa quantidade de carboidratos solúveis e um pequeno número de lactobacilos, quando comparada a outras culturas. Durante a fermentação da silagem, pode não haver produção suficiente de ácido lático pelos lactobacilos para inibir o crescimento de bactérias prejudiciais, resultando em uma silagem de baixa qualidade. Portanto, freqüentemente tem sido recomendado o uso de inoculantes microbianos para o controle de microrganismos indesejáveis durante sua fermentação (CAI et al., 1999b).

Recentemente há uma tendência à inoculação de bactérias ácido láticas para dominar a fase inicial do processo fermentativo (BOLSEN et al., 1989). As mudanças esperadas com tal inoculação na silagem incluem um rápido declínio no $\mathrm{pH}$, uma diminuição da concentração de nitrogênio amoniacal por causa da inibição da 
proteólise, decréscimo nos níveis de acetato e butirato e um aumento no conteúdo de ácido lático (KUNG et al., 1984). O uso de inoculantes microbianos parece ser mais interessante que os aditivos químicos, uma vez que são mais fáceis de serem manejados e não corroem o maquinário utilizado (MUCK, 1988). Contudo, sabe-se que os efeitos da inoculação microbiana na silagem de alfafa são bastante variáveis (BOLSEN et al., 1989 e MUCK, 1988). Em alguns estudos, a inoculação produziu pequena melhora na qualidade da silagem (GORDON, 1989b), mas em muitos estudos têm produzido uma maior eficiência fermentativa com redução das perdas de matéria seca, melhorando com isso a digestibilidade (RICE et al., 1990) e aumentando o crescimento dos animais ou, em outros estudos, aumentando a produção leiteira (GORDON, 1989a). Ainda segundo KENNEDY (1990); PHILLIP et al. (1990) e FREDEEN et al. (1991), os inoculantes demonstraram não melhorar significativamente a preservação da silagem e o desempenho animal. Esse resultado também foi observado por STOKES (1992), que trabalhando com culturas bacterianas homofermentativas, concluiu que a inoculação aumentou a eficiência fermentativa da silagem, mas não melhorou seu valor nutricional, consumo, ou desempenho animal. McALLISTER et al. (1998) obtiveram aumento no consumo de matéria seca, no ganho de peso diário e na eficiência alimentar, comparando silagem inoculada com Lactobacillus plantarum e Enterococcus faecium, ao grupo controle.

CAI et al. (1998), utilizando Weissella paramesenteroides e Leuconostoc pseudomesenteroides na inoculação de silagem de alfafa, obtiveram maior $\mathrm{pH}$ e maiores concentrações de ácido butírico e nitrogênio amoniacal, comparando com silagem inoculada com Lactobacillus casei, que também reduziu a produção de gás e as perdas de matéria seca, verificando assim, que as cepas heterofermentativas não melhoraram a 
qualidade da silagem e ainda causaram perdas na fermentação, quando comparadas com as homofermentativas.

Silagens com boa fermentação, altamente digestíveis, contendo altas concentrações de ácido lático e baixas de ácido acético, nitrogênio amoniacal e concentração de parede celular, estão associadas com alto consumo e melhora no desempenho animal (NADEAU et al., 2000).

KUNG et al. (1991), em uma pesquisa utilizando inoculante microbiano (Lactobacillus plantarum) e/ou antibiótico (Vancomicina) na silagem de alfafa, verificaram que os silos tratados com o inoculante tenderam a ter uma diminuição do número de leveduras e fungos a partir do $5^{\circ}$ dia do período de ensilagem, além de que a quantidade de coliformes também foi diminuída com relação ao grupo controle. Um rápido decréscimo dos coliformes pode ter um importante papel, onde LINDGREN et al. (1985) reportaram que a adição de inoculantes microbianos reduziu os níveis de enterobactérias e de endotoxinas na silagem. Um grande aumento no número de bactérias láticas no período inicial (primeiras 24 horas) do processo de ensilagem foi observado por MOON et al. (1981) e SEALE et al. (1986). FREDEEN et al. (1991), utilizando a inoculação de Lactobacillus plantarum e Pediococcus acidilactici, verificaram que não houve alteração no número de colônias das mesmas depois do $150^{\circ}$ dia do processo. Porém, a inoculação causou um marcante aumento na concentração de ácido lático e diminuição nas concentrações de ácido acético e nitrogênio amoniacal. MUCK (1989) verificou que, para melhorar a qualidade da silagem, o fornecimento de bactérias ácido láticas deveria ser em níveis maiores que $10 \%$ em relação a população bacteriana presente. CAI et al. (1999a) verificaram que silagens de alfafa tratadas com Lactobacillus casei e Lactobacillus plantarum foram bem preservadas; tiveram um 
valor significativamente mais baixo de $\mathrm{pH}$, ácido butírico, ácido propiônico, concentrações do nitrogênio amoniacal, produção de gás e perdas de matéria seca. Da mesma forma que observaram maior conteúdo residual de carboidratos solúveis e ácido lático do que o obtido na silagem controle, embora não tivessem demonstrado melhora no crescimento de leveduras ou deterioração aeróbia. SINGH et al. (1996), utilizando bactérias ácido láticas (Streptococcus faecalis e Lactobacillus plantarum) e melaço (5\%) na inoculação da silagem de alfafa, observaram diminuição da matéria seca e do pH. A adição conjunta obteve melhor resultado na diminuição do $\mathrm{pH}$ do que apenas com o melaço. Utilizando somente as bactérias na inoculação houve aumento significativo do nitrogênio amoniacal e do ácido lático, bem como diminuição do ácido butírico, embora não tenha afetado as concentrações de ácido acético.

A proteína da alfafa é sujeita a sofrer uma extensa degradação durante o processo de ensilagem. Cerca de 75 a $87 \%$ do total de nitrogênio presente na silagem de alfafa pode ser de nitrogênio não protéico (MUCK, 1987). Evidências experimentais indicam que o excesso de degradação ruminal resulta em um ineficiente aproveitamento da proteína da alfafa, o que pode diminuir o rendimento leiteiro e a própria proteína do leite (BRODERICK, 1985). Limitando as proteases durante o processo de ensilagem de forrageiras como a alfafa e a subseqüente redução dos componentes de nitrogênio não protéico podem resultar em um aumento potencial da degradação do nitrogênio insolúvel no rúmen, acontecimento, este, desejável para o animal. Essas proteases podem ser parcialmente inibidas pelo rápido declínio do $\mathrm{pH}$ durante a fermentação. BRODERICK et al. (1990) relataram que, ensilando a alfafa com 30 a 50\% de matéria seca, o conteúdo de NNP foi de 62 a 76\%. SHEPERD et al. (1995) trabalhando com a inoculação de 2 produtos a base de bactérias láticas mais enzimas, verificaram que nas 
silagens tratadas houve uma diminuição do nitrogênio amoniacal em relação ao controle. Tal diminuição provavelmente foi resultado de uma restrição da proteólise pelo conteúdo de matéria seca da silagem. Entretanto, a inoculação bacteriana também reduziu o conteúdo de nitrogênio amoniacal na silagem e poderia ser parcialmente responsável por esses achados (ROOKE et al., 1988; GORDON, 1989a e KUNG et al., 1990).

Uma quantidade de matéria seca de aproximadamente $26 \%$ é o mínimo requerido para a preservação do material ensilado. Esse valor mínimo pode ser conseguido pela pré-secagem do material antes da ensilagem ou pela adição de material absorvente. Em culturas ricas em matéria seca quando ensiladas, menos ácido é formado, menos carboidratos são fermentados e menor será a proteólise (MUCK, 1988). Quando o conteúdo de matéria seca é relativamente alto na silagem, a atividade clostridiana é baixa (LEIBENSPERGER e PITT, 1987) e a proteólise é substancialmente reduzida pelo aumento de matéria seca (MUCK, 1987). Em geral, há uma demora no declínio do $\mathrm{pH}$ da silagem, o que dificulta a redução da proteólise. Entretanto, a rápida diminuição do $\mathrm{pH}$ é importante na produção de silagem de boa qualidade quando o conteúdo de matéria seca é menor ou igual a 50\%.

A preservação da cultura forrageira no silo depende de ácidos orgânicos suficientes para inibir o catabolismo celular e inibir o desenvolvimento microbiano. Um rápido declínio do $\mathrm{pH}$ (em menos de 48 horas) é particularmente importante quando são ensiladas culturas que, como alfafa, possuem alto conteúdo de proteína bruta, uma vez que a atividade das enzimas proteolíticas não são inibidas até que o pH decresça para 4,0 a 4,5 (McDONALD et al., 1991), dependendo do conteúdo de umidade. MUCK e PITT (1993) verificaram que a alta produção de ácido lático decresce o pH para 
próximo de 4,0 e limita a atividade proteolítica. No trabalho realizado por KUNG et al. (1990) foi concluído que o $\mathrm{pH}$ da silagem inoculada com bactérias acido láticas foi marcantemente diminuído do $3^{\circ}$ ao $56^{\circ}$ dia do processo fermentativo. Segundo o estudo realizado por STOKES (1992), comparando os efeitos do uso de misturas enzimáticas e/ou inoculantes (bactérias homoláticas) na fermentação e composição da silagem, foi observado que houve diminuição do pH da silagem tratada. Essa diminuição foi devida a um aumento na concentração de ácido lático e aumento da relação lático:acético. SEALE et al. (1986) verificaram que o desaparecimento dos coliformes da silagem de alfafa estava associado ao rápido declínio do $\mathrm{pH}$. Isso está de acordo com os estudos de LINDGREN et al. (1985), que encontraram que um rápido decréscimo do $\mathrm{pH}$ na inoculação de silagem de alfafa foi acompanhado por uma rápida diminuição do número de Enterobactérias. Esporos de clostrídios fementadores de lactato foram detectados em silagens com altos e baixos níveis de pH (BOLSEN et al., 1992), o que contrasta com os resultados de SEALE et al. (1986), que encontraram os mesmos tipos de esporos somente em silagens com $\mathrm{pH}$ acima de 4,5. Esses microrganismos podem fermentar o ácido lático, formando o ácido butírico, que levaria a um aumento do $\mathrm{pH}$ do material ensilado.

Se a capacidade de tamponamento do citoplasma celular for limitado, uma menor quantidade de ácido lático será necessária para abaixar o pH para 4,5. Comparativamente, altas concentrações de $\mathrm{K}, \mathrm{Mg}$ e $\mathrm{Ca}$ na alfafa, diferente de outras culturas como o milho, podem ter o papel de sistema tampão na silagem por formar sais com os produtos finais da fermentação, o que aumenta o tempo, bem como a quantidade de ácido necessária para promover a preservação do material (SMITH, 1962). SHEPERD et al. (1995) realizaram um experimento utilizando 2 tipos de aditivos 
contendo bactérias e enzimas: o aditivo "A" possuía L. plantarum, P. cereviseae, amilase, celulase e pectinase; e o aditivo "B" possuía L. plantarum, P. acidilactici, amilase e celulase, comparados com o controle. A capacidade tampão no dia 0 foi 21,5 , 20,7 e $19,7 \%$ e no $177^{\circ}$ dia $19,7,20,0$ e $20,2 \%$, respectivamente para silagem "A", "B" e controle.

AISAN et al. (1997), utilizando bactérias ácido láticas, celulase ou ácido fórmico na inoculação de silagens de alfafa, verificaram que a celulase aumentou a degradação do tecido parenquimatoso do caule, enquanto que o ácido fórmico diminuiu e os lactobacilos tiveram pouco efeito sobre este parâmetro, sendo este achado confirmado através das perdas de FDN e FDA durante a fermentação.

KENT et al. (1988) observaram uma tendência no aumento do consumo por vacas em lactação alimentadas com silagem de alfafa inoculada com $L$. plantarum e $P$. acidilactici, mas o efeito não foi estatisticamente significativo. KUNG et al. (1984) também perceberam ausência de efeito significativo no consumo de matéria seca por vacas em lactação, apesar da melhora na qualidade da silagem de alfafa quando inoculada.

Experimentos realizados no Estado de São Paulo mostraram que a inoculação microbiana da silagem de alfafa diminuiu os teores de ácido acético e aumentou os teores de etanol e o $\mathrm{pH}$ da silagem sem adição de polpa cítrica, mas não da silagem adicionada de polpa (ALMEIDA et al., 1999). Para o milho não se observou efeitos significativos da inoculação sobre a fermentação, embora a inoculação com $L$. plantarum e $S$. faecium tenha aumentado os teores de carboidratos solúveis (RUZANTE et al., 1999). Na inoculação (S. faecium, P. acidilactici, L. plantarum, amilase, hemicelulase e celulase) da silagem de sorgo, verificou-se uma diminuição no teor de 
matéria seca e aumento no teor de fibra em detergente neutro, na concentração de etanol e das perdas de matéria seca (SENATORE et al., 1999). Entretanto, na silagem de girassol inoculada com L. plantarum e S. faecium houve aumento nas concentrações de carboidratos solúveis, etanol, amido e do poder tampão, e diminuição nas concentrações de nitrogênio amoniacal, ácido acético e do $\mathrm{pH}$; porém sem efeito sobre os teores de matéria seca, proteína bruta, lignina, digestibilidade in vitro da matéria seca, concentrações de ácido lático ou sobre a estabilidade aeróbia (RODRIGUES et al., 2001a). Para o capim elefante a inoculação (L. plantarum e S. faecium) melhorou o perfil fermentativo; a relação lactato:acetato foi melhorada e o $\mathrm{pH}$ diminuído, porém, aumentou a concentração de nitrogênio insolúvel em detergente ácido (FERNANDES et al., 1999).

O mesmo grupo de pesquisa estudando a digestibilidade total em carneiros alimentados com silagem de girassol inoculada (L. plantarum e S. faecium), verificaram aumento da digestibilidade dos extrativos não nitrogenados e diminuição da digestibilidade da fibra bruta e fibra em detergente ácido, mas nenhum efeito sobre a digestibilidade total da matéria seca, proteína bruta, extrato etéreo, fibra em detergente neutro, amido ou do nutrientes digestíveis totais (RODRIGUES et al., 2001c). Estes autores (RODRIGUES et al., 2001d, e, f), avaliando também a inoculação ( $L$. plantarum e $S$. faecium) da silagem de capim-elefante ou de milho e a adição de inoculante (L. plantarum, S. faecium, P. acidilactici, amilase, hemicelulase e celulase) na silagem de sorgo, não observaram efeito sobre as variáveis citadas acima, bem como sobre o consumo de matéria seca digestível ou consumo de nutrientes digestíveis totais; notaram apenas uma tendência em diminuir a digestibilidade do extrato etéreo nas silagens de sorgo e milho, e em aumentar a digestibilidade dos extrativos não 
nitrogenados na silagem de capim-elefante. E ainda, testando a digestibilidade total em carneiros alimentados com silagem de alfafa controle ou inoculada com L. plantarum e P. pentosaceus, notaram aumento da digestibilidade da matéria seca, extrativos não nitrogenados, fibra em detergente neutro, fibra em detergente ácido, amido e nutrientes digestíveis totais, mas nenhum efeito sobre o teor de proteína bruta, extrato etéreo ou fibra bruta (RODRIGUES et al., 2001b).

\section{4 - Referências bibliográficas}

AISAN, A.; OKAMOTO, M.; YOSHIHIRA, T.; ATAKU, K.; NARASAKI, N. Effect of ensiling with Acremonium cellulase, lactic acid bacteria and formic acid on tissue structure of timothy and alfalfa. Asian Austral. J. Anim. Sci., v. 10, n. 6, p. 593-598, 1997.

ALCÂNTARA, P. B. Leguminosas. In:__. Plantas Forrageiras: gramíneas e leguminosas. 4. ed.rev. e ampl. São Paulo: Nobel, 1988. p. 69-116.

ALMEIDA, L. F. S.; RUZANTE, J. M.; LUCCI, C. S.; MELOTTI, L.; ANDRADE, S. J. T.; LIMA, F. R.; RODRIGUES, P. H. M.; SOUZA, A. A. Efeitos da adição de inoculantes enzimo-bacterianos sobre o perfil fermentativo da silagem de alfafa e polpa cítrica. In: SIMPÓSIO DE INICIAÇÃO CIENTÍFICA DA USP, 7., 1999, Piracicaba. Anais... Piracicaba: FEALQ, 1999. p. 375.

ARAÚJO, A. A. Leguminosas perenes. In:__. Forrageiras para ceifa: capineiras, pastagens, fenação e ensilagem. 3. ed. Porto Alegre: Sulina, 1978. cap. 4, p. 41-82.

BARRY, T. N.; DI MENNA, M. E.; WEBB, P. R.; PARLE, J. N. Some observations on aerobic deterioration in untreated silages and in silages made with formaldehydecontaining additives. J. Sci. Food Agric., v. 31, n. 2, p. 133-146, 1980.

BOLSEN, K. K.; LAYTINI, A.; HART, R. A.; NUSBACK, L.; NIROOMAND, F. Effect of commercial inoculants on fermentation of 1987 and 1988. Kansas Silage Crops. Des Moines: Pionner Hi-Bred Int., 1989. p. 1-19.

BOLSEN, K. K.; LIN, C.; BRENT, B. E.; FEYERHERM, A. M.; URBAN, J. E.; AIMUTIS, W. R. Effect of silage additives on the microbial succession and fermentation process of alfalfa and corn silages. J. Dairy Sci., v. 75, n. 11, p. 30663083, 1992. 
BRODERICK, G. A. Alfalfa silage or hay versus corn silage as the sole forage for lactating dairy cows. J. Dairy Sci., v. 68, n. 12, p. 3262-3271, 1985.

BRODERICK, G. A.; RICKER, D. B.; DRIVER, L. S. Expeller soybean meal and corn by-products versus solvent soybean meal for lactating dairy cows fed alfalfa silage as sole forage. J. Dairy Sci., v. 73, n. 2, p. 453-462, 1990.

BROUK, M.; BELYEA, R. Chewing activity and digestive responses of cows fed alfalfa forages. J. Dairy Sci., v. 76, n. 1, p. 175-182, 1993.

CAI, Y.; BENNO, Y.; OGAWA, M.; KUMAI, S. Effect of applying lactic acid bacteria isolated from forage crops on fermentation characteristics and aerobic deterioration of silage. J. Dairy Sci., v. 82, n. 3, p. 520-526, 1999a.

CAI, Y.; BENNO, Y.; OGAWA, M.; OHMOMO, S.; KUMAI, S.; NAKASE, T. Influence of Lactobacillus spp. from an inoculant and of Weissela and Leuconostoc spp. from forage crops on silage fermentation. Appl. Environ. Microbiol., v. 64, n. 8, p. 2982-2987, 1998.

CAI, Y.; KUMAI, S.; OGAWA, M.; BENNO, Y.; NAKASE, T. Characterization and identification of Pediococcus species isolated from forage crops and their application for silage preparation. Appl. Environ. Microbiol., v. 65, n. 7, p. 2901-2906, 1999 b.

CHEN, J.; STOKES, M. R.; WALLACE, C. R. Effects of enzyme-inoculant systems on preservation and nutritive value of haycrop and corn silages. J. Dairy Sci., v. 77, n. 2, p. 501-512, 1994.

CLEALE, R. M.; FIRKINS, J. L.; VAN DER BEEK, F.; CLARK, J. H.; JASTER, E. H.; McCOY, G. C.; KLUSMEYER, T. H. Effect of inoculation of whole plant corn forage with Pediococcus acidilactici and Lactobacillus xylosus on preservation of silage and heifer growth. J. Dairy Sci., v. 73, n. 3, p. 711-718, 1990.

FERNANDES, T.; RODRIGUES, P. H. M.; ANDRADE, S. J. T.; MELOTTI, L.; LUCCI, C. S.; LIMA, F. R. Efeitos da adição de inoculantes bacterianos sobre a composição bromatológica e perfil fermentativo da silagem de capim elefante produzida em silos experimentais. In: SIMPÓSIO DE INICIAÇÃO CIENTÍFICA DA USP, 7., 1999, Piracicaba. Anais... Piracicaba: FEALQ, 1999. p. 373.

FOX, D. G. Systems for storing and handling high moisture corn. In: HIGH MOISTURE GRAINS SYMP, 1976, Stillwater. Stillwater: Oklahoma State Univ., 1976. p. 15.

FREDEEN, A. H.; McQUEEN, R. E.; BROWNING, D. A. Effects of enzymes and nutrients in a bacterial inoculant on quality of timothy or alfalfa silage and dairy cow performance. Can. J. Anim. Sci., v. 71, n. 3, p. 781-791, 1991. 
FROETSCHEL, M. A.; ELY, L. O.; AMOS, H. E. Effects of additives and growth environment on preservation and digestibility of wheat silage fed to Holstein heifers.

J. Dairy Sci., v. 74, n. 2, p. 546-556, 1991.

GOODRICH, R. D.; MEISKE, J. C. Influence of maturity and moisture content on the fermentation of high moisture corn. In: HIGH MOISTURE GRAINS SYMPOSIUM, 1976, Stillwater. Stillwater: Oklahoma State Univ., 1976. p. 51.

GORDON, F. J. An evaluation through lactating cattle of a bacterial inoculant as an additive for grass silage. Grass Forage Sci., v. 44, n. 2, p. 169-179, 1989a.

GORDON, F. J. The principles of making and storing high quality, high intake silage. In: BRITISH GRASSLAND SOCIETY OCCASIONAL SYMPOSIUM, 23., 1989, Brighton. Proceedings... Brighton. 1989b. p. 3-19.

HAIGH, P. M.; PARKER, J. W. G. Effect of silage additives and wilting on silage fermentation, digestibility and intake, and on live weight changes of young cattle. Grass Forage Sci., v. 40, n. 4 , p. 429-435, 1985.

HARRISON, J. H.; BLAUWIEKEL, R.; STOKES, M. R. Fermentation and utilization of grass silage. J. Dairy Sci., v. 77, n. 10, p. 3209-3235, 1994.

HATTORI, I.; KUMAI, S.; FUKUMI, R.; BAYORBOR, T. The effect of some additives on aerobic deterioration of corn silage. Anim. Sci. Technol., v. 65, n. 6, p. 547-550, 1994.

HENDERSON, A. R.; McDONALD, P. The effect of a range of commercial inoculants on the biochemical changes during the ensilage of grass in laboratory studies. Res. Dev. Agric., v. 1, n. 2, p. 171-175, 1984.

HENDERSON, N. Silage additives. Anim. Feed Sci. Technol., v. 45, n. 1, p. 35-56, 1993.

HONIG, H.; WOOLFORD, M. K. Changes in silage on exposure to air. In: BRITISH GRASSLAND SOCIETY OCCASIONAL SYMPOSIUM, 11., 1980, Brighton. Proceedings... Brighton. 1980. p.76-86.

JACOBS, J. L.; McALLAN, A. B. Protein supplementation of formic acid and enzymetreated silages. 2. Nitrogen and amino acid digestion. Grass Forage Sci., v. 47, n. 2, p. 114-120, 1992.

JUSCAFRESA, B. Leguminosas forrageiras. In: __. Forragens: fertilização, características e valor nutritivo. Litexa, Portugal: AEDOS, 1982. cap. 6:, p. 43-73.

KENNEDY, S. J. An evaluation of three bacterial inoculants and formic acid as additives for first harvest grass. Grass Forage Sci., v. 45, n. 3, p. 281-288, 1990. 
KENT, B. A.; ARAMBEL, M. J.; WALTERS, J. L. Effect of bacterial inoculant on alfalfa haylage: ensiling characteristics and milk production response when fed to dairy cows in early lactation. J. Dairy Sci., v. 71, n. 9, p. 2457-2461, 1988.

KUNG JUNIOR, L.; CARMEAN, B. R.; TUNG, R. S. Microbial inoculation or cellulase enzyme treatment of barley and vetch silage harvested at three maturities.

J. Dairy Sci., v. 73, n. 5, p. 1304-1311, 1990.

KUNG JUNIOR, L.; TUNG, R. S.; MACIOROWSKI, K. G. Effect of a microbial inoculant (Ecosyl TM) and/or a glycopeptide antibiotic (vancomycin) on fermentation and aerobic stability of wilted alfalfa silage. Anim. Feed Sci. Technol., v. 35, n. 1, p. 37-48, 1991.

KUNG JUNIOR, L.; GRIEVE, D. B.; THOMAS, J. W.; HUBER, J. T. Added ammonia or microbial inocula for fermentation and nitrogenous compounds of alfalfa ensiled at various percents of dry matter. J. Dairy Sci., v. 67, n. 2, p. 299-306, 1984.

LEIBENSPERGER, R. Y.; PITT, R. E. A model of clostrial dominance in ensilage. Grass Forage Sci., v. 42, n. 3, p. 297-317, 1987.

LINDGREN, S.; KASPERSSON, A.; RYDBERG, E.; LINGVALL, P.; KARTZOW, A. Effect of inoculants, grain, and formic acid on silage fermentation. Swed. J. Agric. Res., v. 13, n. 2, p. 91-100, 1983.

LINDGREN, S.; PETTERSSON, K.; JONSSON, A.; LINGVALL, P.; KASPERSSON, A. Silage inoculation selected strains, temperature, wilting and pratical aplication. Swed. J. Agric. Res., v. 15, n. 1, p. 9-18, 1985.

McALLISTER, T. A.; FENIUK, R.; MIR, Z.; MIR, P.; SELINGER, L. B.; CHENG, K. J. Inoculants for alfalfa silage: effects on aerobic stability, digestibility and the growth performance of feedlot steers. Livest. Prod. Sci., v. 53, n. 2, p. 171-181, 1998.

McDONALD, P.; HENDERSON, A. R. Buffering capacity of herbage samples as a factor in ensilage. J. Sci. Food Agric., v. 13, n.3, p. 395-400, 1962.

McDONALD, P.; HENDERSON, A. R.; HERON, S. J. E. The biochemistry of silage. 2. ed. Marlow: Chalcombe Publications, 1991. 340 p.

MOON, N. J.; ELY, L. O.; SUDWEEKS, E. M. Fermentation of wheat, corn, and alfalfa silages inoculated with Lactobacillus acidophilus and Candida sp. at ensiling. J. Dairy Sci., v. 64, n. 5, p. 807-813, 1981.

MUCK, R. E. Dry matter level effects on alfalfa silage quality. I. Nitrogen transformations. Trans. Am. Soc. Agric. Eng., v. 30, n. 1, p. 7-14, 1987.

MUCK, R. E. Factors influencing silage quality and their implications for management. J. Dairy Sci., v. 71, n. 11, p. 2992-3002, 1988. 
MUCK, R. E. Initial bacterial numbers on lucerne prior to ensiling. Grass Forage Sci., v. 44, n. 1, p. 19-25, 1989.

MUCK, R. E.; PITT, R. E. Ensiling and its effect on crop quality. In: NATIONAL SILAGE PRODUCTION CONFERENCE., 1993, Ithaca. Proceedings... Ithaca: Northeast Reg. Agric. Ext. Serv., 1993. p. 57-66.

NADEAU, E. M. G.; BUXTON, D. R.; RUSSEL, J. R.; ALLISON, M. J.; YOUNG, J. W. Enzyme, bacterial inoculant, and formic acid effects on silage composition of orchardgrass and alfalfa. J. Dairy Sci., v. 83, n. 7, p. 1487-1502, 2000.

NUERNBERG, N. J. Técnicas de produção de alfafa. In: CONGRESSO BRASILEIRO DE PASTAGENS, 1986, Piracicaba. Anais... Piracicaba: FEALQ, 1986. p.145.

OHYAMA, Y.; MASAKI, S.; HARA, S. Factors influencing aerobic deterioration of silages of italian ryegrass and changes in chemical composition after opening silos.

J. Sci. Food Agric., v. 26, n. 8, p. 1137-1147, 1975.

PHILLIP, L. E.; UNDERHILL, L.; GARINO, H. Effects of treating lucerne with an inoculum of lactic acid bacteria or formic acid upon chemical changes during fermentation, and upon the nutritive value of the silage for lambs. Grass Forage Sci., v. 45, n. 3, p. 337-344, 1990.

POLAN, C. E.; STIEVE, D. E.; GARRETT, J. L. Protein preservation and ruminal degradation of ensiled forage treated with heat, formic acid, ammonia, or microbial inoculant. J. Dairy Sci., v. 81, n. 3, p. 765-776, 1998.

RICE, D. W.; SODERLUND, S. D.; PHILlIP, I. E.; HARRISON, J. H. Effect of microbial inoculation on the digestibility of legume silages. J. Dairy Sci., v. 73, p. 195, 1990. Supplement, 1.

RODRIGUES, P. H. M.; ALMEIDA, T. F.; MELOTTI, L.; ANDRADE, S. J. T.; PEIXOTO JÚNIOR, K. C. Efeitos da adição de inoculantes microbianos sobre a composição bromatológica e sobre a fermentação da silagem de girassol produzida em silos experimentais. Rev. Bras. Zootec., v. 30, p. 2169-2175, 2001a. Supplement, 6.

RODRIGUES, P. H. M.; ANDRADE, S. J. T.; ALMEIDA, L. F. S.; MEYER, P. M.; LIMA, F. R.; LUCCI, C. S. Inoculação microbiana da alfafa para ensilagem sobre a digestibilidade aparente em carneiros. Rev. Bras. Zootec., v. 30, n. 6, p. 1925-1930, $2001 b$.

RODRIGUES, P. H. M.; ANDRADE, S. J. T.; ALMEIDA, T. F.; MEYER, P. M.; MELOTTI, L. Valor nutritivo de silagens inoculadas com bactérias ácido-láticas. 3 . Inoculação da silagem de girassol. In: REUNIÃO ANUAL DA SOCIEDADE BRASILEIRA DE ZOOTECNIA, 38., 2001, Piracicaba. Anais... Piracicaba: SBZ, 2001c. p. 915-916. 
RODRIGUES, P. H. M.; ANDRADE, S. J. T.; FERNANDES, T.; LIMA, F. R.; MELOTTI, L.; LUCCI, C. S. Valor nutritivo da silagem de capim-elefante cultivar Napier (Pennisetum purpureum, Schum) inoculada com bactérias ácido-láticas. Acta Scientiarum, v. 23, n. 4, p. 809-813, 2001d.

RODRIGUES, P. H. M.; ANDRADE, S. J. T.; RUZANTE, J. M.; LIMA, F. R.; MELOTTI, L. Valor nutritivo de silagens inoculadas com bactérias ácido-láticas. 1. Inoculação da silagem de milho. In: REUNIÃO ANUAL DA SOCIEDADE BRASILEIRA DE ZOOTECNIA, 38., 2001, Piracicaba. Anais... Piracicaba: SBZ, 2001e. p. 920-921.

RODRIGUES, P. H. M.; SENATORE, A. L.; LUCCI, C. S.; ANDRADE, S. J. T.; LIMA, F. R.; MELOTTI, L.Valor nutritivo de silagens inoculadas com bactérias ácidoláticas. 2. Inoculação da silagem de sorgo. In: REUNIÃO ANUAL DA SOCIEDADE BRASILEIRA DE ZOOTECNIA, 38., 2001, Piracicaba. Anais... Piracicaba: SBZ, 2001f. p. 918-920.

ROOKE, J. A.; MAYA, F. M.; ARNOLD, J. A.; ARMSTRONG, D. G. The chemical composition and nutritive value of grass silages prepared with no additive or with the application of additives containing either Lactobacillus plantarum or formic acid. Grass Forage Sci., v. 43, n. 1, p. 87-95, 1988.

RUZANTE, J. M.; SENATORE, A. L.; LIMA, F. R.; MELOTTI, L.; ANDRADE, S. J. T.; RODRIGUES, P. H. M.; SOUZA, A. A. Avaliação do uso de inoculantes biológicos sobre a qualidade fermentativa e nutricional da silagem de milho. In: SIMPÓSIO DE INICIAÇÃO CIENTÍFICA DA USP, 7., 1999, Piracicaba. Anais... Piracicaba: FEALQ, 1999. p. 373.

SCHAEFER, D. M.; BROTZ, P. G.; ARP, S. C.; COOK, D. K. Inoculation of corn silage and high-moisture corn with lactic acid bacteria and its effects on the subsequent fermentations and on feedlot performance of beef steers. Anim. Feed Sci. Tech., v. 25, n. 1, p. 23-38, 1989.

SEALE, D. R.; HENDERSON, A. R.; PETTERSON, K. O.; LOWE, J. F. The effect of addition of sugar and inoculation with two commercial inoculants on the fermentation of lucerne silage in laboratory silos. Grass Forage Sci., v. 41, n. 1, p. 61-70, 1986.

SENATORE, A. L.; RODRIGUES, P. H. M.; ANDRADE, S. J. T.; RUZANTE, J. M.; LUCCI, C. S.; LIMA, F. R. Efeitos da adição de inoculantes bacterianos sobre a composição bromatológica e perfil fermentativo da silagem de sorgo produzida em silos experimentais. In: SIMPÓSIO DE INICIAÇÃO CIENTÍFICA DA USP, 7., 1999, Piracicaba. Anais... Piracicaba: FEALQ, 1999. p. 376.

SHEPERD, A. C.; MASLANKA, M.; QUINN, D.; KUNG JUNIOR, L. Additives containing bacteria and enzymes for alfalfa silage. J. Dairy Sci., v. 78, n. 3, p. 565-572, 1995. 
SINGH, A.; EDWARD, J. C.; MOR, S.; SINGH, K. Biochemical changes during ensiling of wilted lucerne with inoculation of lactic acid bacteria and molasses. Indian J. Anim. Nutrition, v. 13, n. 2, p. 77-82, 1996.

SMITH, L. H. Theoretical carbohydrate requeriment for alfalfa silage production. Agron. J., v. 54, n.1, p. 291-296, 1962.

SPECKMAN, C. A.; PHILlIPS, R. M.; LINNERTZ, D. P.; BERGER, J. C. A.; CARVER, L. A.; PARKER, R. B. Lactobacillus populations of the epiphytic flora of corn just prior to ensiling. J. Anim. Sci., v. 53, p. 432, 1981. Supplement, 1.

STOKES, M. R. Effects of an enzyme mixture, an inoculant, and their interaction on silage fermentation and dairy production. J. Dairy Sci., v. 75, n. 3, p. 764-773, 1992.

TENGERDY, R. P.; WEINBERG, Z. G.; SZAKACS, G.; WU, M.; LINDEN, J. C.; HENK, L. L.; JOHNSON, D. E. Ensiling alfalfa with additives of lactic acid bacteria and enzymes. J. Sci. Food Agric., v. 55, n. 2, p. 215-228, 1991.

TOSI, H. Ensilagem de gramíneas tropicais sob diferentes tratamentos. $1973.107 \mathrm{f}$. Tese (Doutorado em Nutrição e Produção Animal) - Faculdade de Ciências Médicas e Biológicas, Universidade do Estado de São Paulo, Botucatu.

WARDYNSKI, F. A.; RUST, S. R.; YOKOYAMA, M. T. Effect of microbial inoculation of high-moisture corn on fermentation characteristics, aerobic stability, and cattle performance. J. Anim. Sci., v. 71, n. 8, p. 2246-2252, 1993.

WHITTENBURRY, R. Microbiology of grass silage. Process Biochemistry, v. 3, p. 27-31, 1968.

WHITTENBURRY, R.; McDONALD, P.; BRYAN JONES, D. G. A short review of some biochemical and microbiological aspects of ensilage. J. Sci. Food. Agric., v. 18, n. 2, p. 441-444, 1967.

WILKINSON, J. M. Silage made from tropical and temperate crops. 1. The ensiling process and its influence on feed value. World Anim. Rev., n. 45, p. 36-42, 1983.

WILKINSON, J. M.; KILKENNY, J. B. The conservation and utilization of maize silage. 2. ed. Tunbridge Wells: Maize Development Association, 1977. p.1-46.

WOOLFORD, M. K. The detrimental effects of air on silage. J. Appl. Microbiol., v. 68, n. 2, p. 101-116, 1990.

WOOLFORD, M. K. The silage fermentation. New York: Marcel Dekker, 1984. 350 p. 


\title{
CAPÍTULO III
}

\section{EFEITOS DA ADIÇÃO DE INOCULANTE MICROBIANO SOBRE A COMPOSIÇÃO BROMATOLÓGICA, FERMENTAÇÃO \\ E ESTABILIDADE AERÓBIA DA SILAGEM \\ PRÉ-SECADA DE ALFAFA}

\begin{abstract}
RESUMO - O presente estudo objetivou avaliar os efeitos do inoculante microbiano Silobac ${ }^{\circledR}$ (L. plantarum, P. pentosaceus), na silagem pré-secada de alfafa, em 22 silos, sendo 11 destes submetidos ao tratamento com inoculante. A alfafa foi cortada quando em estádio do meio do florescimento e os silos confeccionados em fardos de aproximadamente $600 \mathrm{~kg}$ revestidos com película de PVC branca. Amostras foram coletadas logo após a abertura de cada silo para análise da composição bromatológica e perfil fermentativo. $\mathrm{O}$ inoculante diminuiu o teor de MS (inoculada = 44,7 vs. controle $=51,2 \%$, aumentou a concentração de ácido acético (2,35 vs. 0,89\% MS) e apresentou tendência em aumentar os teores de carboidratos solúveis (2,97 vs. $2,44 \% \mathrm{MS})$, em relação ao grupo controle. O inoculante também tendeu em diminuir o escore de bolor obtido à $10 \mathrm{~cm}$ de profundidade, mas não a 30 ou $50 \mathrm{~cm}$. Não foram observados efeitos sobre os teores de PB (15,9 vs. 16,4\% MS), NIDN (14,7 vs. 16,2\% do $\mathrm{N}$ total), NIDA (11,2 vs. $11,6 \%$ do $\mathrm{N}$ total), FDN (47,1 vs. 46,7\% MS), FDA (40,2 vs. $39,8 \%$ MS), celulose (29,7 vs. $28,6 \% \mathrm{MS})$, hemicelulose (6,94 vs. 6,89\% MS), LDA (10,4 vs. $11,1 \% \mathrm{MS})$ e amido (0,82 vs. 0,69\% MS), DIVMS (61,6 vs. 62,5\% MS), poder tampão (52,9 vs. 51,7 meq./100g MS), as concentrações de etanol (0,018 vs. $0,024 \% \mathrm{MS})$ e dos ácidos propiônico ( 0,00 vs. $0,00 \% \mathrm{MS})$, butírico $(0,00$ vs. $0,00 \%$ MS) e lático (5,62 vs. 4,45\% MS), a relação lático:acético (4,57 vs. 4,87), bem como sobre o pH (4,96 vs. 5,33), sobre as concentrações de $\mathrm{N}^{-\mathrm{NH}_{3}}(8,19$ vs. $5,21 \%$ do $\mathrm{N}$ total) ou sobre a estabilidade aeróbia.
\end{abstract}

Palavras-chave: ácidos orgânicos, bactérias láticas, Medicago Sativa 


\title{
EFFECTS OF MICROBIAL INOCULANT ON CHEMICAL COMPOSITION, FERMENTATION CHARACTERISTICS AND AEROBIC STABILITY OF ALFALFA HAYLAGE
}

\begin{abstract}
The objective of this study was to evaluate the effects of microbial inoculant Silobac ${ }^{\circledR}$ (L. plantarum, P. pentosaceus) on twenty-two big bales of alfalfa haylage, eleven treated with inoculant. Alfalfa crop was harvested at middle bloom stage and conditioned in bales about $600 \mathrm{~kg}$ capacity and covered with white tube plastic film. Silage was sampled to proceed chemical analyses after each silo was opened. The inoculation decreased DM content (inoculated $=44.7$ vs. control $=51.3 \%$ ), increased acetic acid content (2.35 vs. $0.89 \% \mathrm{DM})$ and tended to increase WSC content (2.97 vs. $2.44 \% \mathrm{DM}$ ) compared to control. It also tended to decrease mould on depth 10 $\mathrm{cm}$, but not on depth 30 or $50 \mathrm{~cm}$. Treatments did not influence CP (15.9 vs. 16.4\% DM), NDIN (14.7 vs. $16.2 \%$ of total N), ADIN (11.2 vs. $11.6 \%$ of total N), NDF (47.1 vs. $46.7 \% \mathrm{DM}), \mathrm{ADF}(40.2$ vs. $39.8 \% \mathrm{DM})$, cellulose (29.7 vs. $28.6 \% \mathrm{DM})$, hemicellulose (6.94 vs. $6.89 \% \mathrm{DM})$, ADL (10.4 vs. $11.1 \% \mathrm{DM})$ and starch contents (0.82 vs. $0.69 \%$ DM), IVDMD (61.6 vs. $62.5 \%$ DM), buffering capacity (52.9 vs. 51.7 meq./100g DM), ethylic alcohol (0.018 vs. $0.024 \%$ DM), propionic (0.00 vs. $0.00 \%$ $\mathrm{DM}$ ), butyric (0.00 vs. $0.00 \% \mathrm{DM})$ and lactic acids contents (5.62 vs. $4.45 \% \mathrm{DM})$, lactic:acetic ratio (4.57 vs. 4.87$), \mathrm{pH}$ (4.96 vs. 5.33), $\mathrm{NH}_{3}-\mathrm{N}$ content (8.19 vs. $5.21 \%$ of total $\mathrm{N}$ ) or aerobic stability.
\end{abstract}

Keywords: lactic acid bacteria, Medicago sativa, organic acids 


\section{Introdução}

O princípio da fermentação da silagem é alcançar uma quantidade de ácido lático suficiente para inibir o crescimento de microrganismos indesejáveis, melhorando assim a preservação dos nutrientes. Normalmente, o número de bactérias ácido láticas presentes nas forragens é baixo (SPECKMAN et al., 1981; WOOLFORD, 1984 e MUCK, 1989) e incluem, primeiramente, espécies heterofermentativas (LINDGREN et al.,1983 e MULLER et al., 1991).

A espécie forrageira, o conteúdo de matéria seca, o substrato disponível, a capacidade de tamponamento e principalmente, o número de espécies de bactérias anaeróbias presentes na forragem interferem na qualidade da fermentação (McDONALD e HENDERSON, 1962; ELY et al., 1981; MOON et al., 1981; ELY et al., 1982; CARR et al., 1984 e KUNG et al., 1984).

Embora apresente alto valor nutritivo, a alfafa possui características indesejáveis para o adequado processo de fermentação, como alta umidade no momento do corte, alto poder tampão, baixos teores de carboidratos solúveis, alto teor protéico e caule tubular e oco que impedem a completa retirada do ar no momento da ensilagem (McALLISTER et al., 1998).

Diversos procedimentos vêm sendo pesquisados visando contornar tais problemas, tal como o uso de inoculantes microbianos, os quais possuem a função de aumentar a população de bactérias láticas no silo e, conseqüentemente, a produção de ácido lático (CLEALE et al., 1990), resultando em rápido declínio no $\mathrm{pH}$, decréscimo nos níveis de acetato e butirato, bem como inibição da proteólise (KUNG et al., 1984). 
Considerando que, durante a abertura, um silo é exposto à deterioração aeróbia, processo caracterizado por aumentos de temperatura, $\mathrm{pH}$ e oxidação dos produtos da fermentação, os inoculantes surgem como alternativa para evitar perdas elevadas.

O objetivo deste estudo foi avaliar o efeito da adição do inoculante microbiano Silobac ${ }^{\circledR}$ sobre a composição bromatológica, perfil fermentativo e estabilidade aeróbia da silagem pré-secada de alfafa.

\section{Material e Métodos}

O trabalho foi conduzido nas dependências do Departamento de Nutrição e Produção Animal da Faculdade de Medicina Veterinária e Zootecnia da Universidade de São Paulo, Campus de Pirassununga.

A cultura de alfafa foi cortada em dezembro de 2000, quando em estádio do meio do florescimento. Após colhido e pré-seco por quatro horas, o material original foi acondicionado em 22 fardos com aproximadamente $150 \mathrm{~cm}$ de altura e $150 \mathrm{~cm}$ de diâmetro (capacidade de 600 quilos), revestidos com película de PVC branca. Os 22 silos foram divididos em dois tratamentos, sendo 11 como controle e outros 11 com a adição do inoculante comercial Silobac ${ }^{\circledR}$ (Chr. Hansen Indústria e Comércio Ltda.), segundo as recomendações do fabricante. De acordo com essas recomendações, o produto fornece $1,0 \times 10^{5}$ unidades formadoras de colônia (Lactobacillus plantarum e Pediococcus pentosaceus) por grama de forragem.

Aproximadamente $600 \mathrm{~kg}$ de massa úmida foram colocadas em cada silo, correspondendo a uma compactação de aproximadamente $230 \mathrm{~kg}$ de silagem $/ \mathrm{m}^{3}$. Os silos foram mantidos fechados por 40 dias expostos às intempéries. 
Uma vez abertos, uma porção retirada de cada silo foi homogeneizada, sendo uma parcela separada para determinação de matéria seca (MS), em estufa de circulação de ar forçado, proteína bruta (PB), segundo AOAC (1980), componentes da parede celular (fibra em detergente neutro - FDN, fibra em detergente ácido - FDA e lignina em detergente ácido - LDA, segundo VAN SOEST, 1967), carboidratos solúveis (JOHNSON et al., 1966), amido (PEREIRA e ROSSI, 1995), nitrogênio insolúvel em detergente ácido (NIDA), nitrogênio insolúvel em detergente neutro (NIDN), segundo VAN SOEST e ROBERTSON (1985), poder tampão (TOSI, 1973) e digestibilidade in vitro da matéria seca (DIVMS) segundo TILLEY e TERRY (1963). Para a determinação da FDN foi omitido o sulfito de sódio, mas adicionada a $\alpha$-amilase. A determinação do amido foi modificada, fazendo a prévia extração dos carboidratos solúveis através da metodologia preconizada por HENDRIX (1993). Outra fração foi colocada em prensa manual para extração dos sucos e imediata determinação do pH (medição em potenciômetro). Parte do suco foi fixada $(1 \mathrm{ml}$ de suco $+0,2 \mathrm{ml}$ de ácido fórmico P.A.) e congelada para posterior determinação dos ácidos orgânicos, por cromatografia gasosa (ERWIN et al., 1961), e do nitrogênio amoniacal $\left(\mathrm{N}_{-} \mathrm{NH}_{3}\right)$ segundo FOLDAGER (1977).

Para a determinação da estabilidade aeróbia da silagem, aproximadamente 2,0 $\mathrm{kg}$ de massa úmida foram retirados de cada fardo, transferidos para caixas de isopor, com capacidade de 5 litros, e armazenados em uma sala com condições de temperatura controlada $\left(25^{\circ} \mathrm{C}\right)$, a fim de permitir tomadas de temperatura ambiental e da silagem às 0, 12, 24, 48, 72, 96 e 120 horas após a abertura dos silos, por meio de um termômetro inserido $10 \mathrm{~cm}$ dentro da massa contida na caixa de isopor. A estabilidade aeróbia foi calculada como uma taxa de elevação de temperatura, usando o máximo da temperatura 
observada dividida pelo tempo necessário para alcançar a máxima temperatura (RUPPEL et al., 1995). Adicionalmente foram avaliados a máxima temperatura alcançada (em $\left.{ }^{\circ} \mathrm{C}\right)$ e o tempo para a obtenção da máxima temperatura (em horas).

A avaliação da porcentagem de bolor das silagens foi realizada visualmente, através do escore de bolor, onde estipulou-se uma escala numérica de 0 a 100 que poderia variar em função da área da silagem embolorada, sendo 0 considerado uma silagem sem bolor aparente e 100 uma silagem com a superfície completamente embolorada. Os escores foram obtidos às profundidades de $10 \mathrm{~cm}, 30 \mathrm{~cm}$ e $50 \mathrm{~cm}$ dentro dos fardos, a medida em que a silagem era consumida.

Os resultados foram analisados através do programa computacional Statistical Analysis System (SAS Institute Inc., 1998). Os dados foram submetidos à análise de variância através do PROC GLM (General Linear Models). Exceto para as variáveis porcentagem de MS e escore de bolor, em todas as demais o modelo estatístico separou como causas de variação efeito de tratamento e a covariável porcentagem de MS na silagem. Para a variável escore de bolor foi adicionado o fator parcelas subdivididas, referentes às diversas profundidades de avaliação. Na presença de interação efeito de tratamento $\mathrm{x}$ efeito de profundidade, a separação de efeito de tratamento foi realizada dentro de cada profundidade. Foi utilizado o nível de significância de 5\% para todos os testes realizados.

\section{Resultados e Discussão}

Os dados de composição bromatológica e digestibilidade in vitro da matéria seca das silagens submetidas ou não aos tratamentos encontram-se na Tabela 1 e Figura 1. A 
adição do inoculante à silagem diminuiu a MS total em 12,8\% (6,6 unidades percentuais) em relação ao grupo controle. É possível que a diminuição da MS seja devido a adição de água para a diluição e homogeneização do inoculante, uma vez que o grupo controle não recebeu adição de água. Entretanto, tal hipótese apresenta difícil sustentação, uma vez que, segundo as recomendações do fabricante, o produto deveria ser diluído em uma quantidade de água que deveria ser adicionada na proporção de 0,2 litros para cada $100 \mathrm{~kg}$ de matéria original. Este valor apresenta-se bastante diferente da mudança de 6,6 unidades percentuais observada entre os tratamentos. Outra possibilidade para explicar os efeitos do inoculante sobre os teores de MS, seria devido às modificações no processo fermentativo das plantas ensiladas, as quais poderiam reduzir o teor de MS em função da produção da "água de metabolismo" (ZAGO, 1991). Mais uma vez, esta hipótese apresenta pouco respaldo científico em virtude dos baixos níveis de carboidratos solúveis presentes nesta forrageira para ser transformado em água. É possível que a melhor explicação para a diferença encontrada nos teores de MS entre as diferentes silagens, seja oriundo da metodologia experimental utilizada, na qual a confecção de uma silagem tratada era seguida por uma silagem controle. Como forma de tentar contornar este problema, as demais variáveis analisadas foram corrigidas pela covariável porcentagem de MS.

Quando utilizaram bactérias ácido láticas (Streptococcus faecalis e Lactobacillus plantarum) na inoculação da silagem de alfafa adicionada de 5\% de melaço, SINGH et al. (1996) observaram a diminuição da MS.

Alguns estudos não perceberam efeito do inoculante sobre a MS em silagens de alfafa (MADER et al., 1985), seja com diferentes teores de umidade (MIR et al., 1995), seja utilizando cepas heterofermentativas (Weissella paramesenteroides e Leuconostoc 
pseudomesenteroides) ou homofermentativa (Lactobacillus casei) em silagens de alfafa ou gramínea (CAI et al., 1998), em silagens inoculadas com P. acidilactici, $P$. pentosaceus ou L. casei, e armazenadas às temperaturas de 25 e $48^{\circ} \mathrm{C}$ (CAI et al., 1999b) e em silagens de alfafa, sorgo ou gramínea com 40 dias de fermentação (CAI et al., 1999a), ou ainda, estudando a adição de inoculantes comerciais (Sil-All ${ }^{\circledR}, \operatorname{Silobac}^{\circledR}$ e Pioneer $1174^{\circledR}$ ) em silagens de girassol (RODRIGUES et al., 2001).

Entretanto, KUNG et al. (1991b), utilizando inoculante microbiano em silagem de alfafa pré-secada, observaram aumento na porcentagem de MS após 60 dias de fermentação, em relação ao controle. Segundo KUNG et al. (1984), quando o teor de MS diminui, a concentração de ácido lático aumenta, resultando em rápida diminuição do $\mathrm{pH}$, porém estes parâmetros não foram observados no presente estudo.

Nenhum efeito foi notado também quanto aos teores de PB, NIDA e NIDN, evidenciando que o aquecimento foi limitado em ambos os tratamentos. Estes dados concordam com os obtidos por MADER et al. (1985); KUNG et al. (1991b) e RODRIGUES et al. (2001), que observaram não haver efeito do inoculante sobre os teores de PB e NIDA. Porém, estão em desacordo com o estudo de POLAN et al. (1998) onde, trabalhando com silagem de alfafa vaporizada e adicionada de inoculante microbiano, ácido fórmico ou a combinação de ambos, observaram diminuição no teor de PB no tratamento com inoculante e diminuição no teor de NIDN em todos os tratamentos, comparado ao grupo controle, não havendo efeito do inoculante ou da combinação sobre o teor de NIDA. Baixas concentrações de NIDA indicam pouca perda por calor durante a fermentação da silagem (MIR et al., 1995), fato que não pode ser demonstrado, em função do inoculante, no presente experimento. 
Nenhum efeito foi observado quanto aos teores de FDN, FDA, LDA, hemicelulose e celulose, o que talvez esteja associado a ausência de efeito sobre o $\mathrm{pH}$, concordando com o estudo de KUNG et al. (1991b), os quais não encontraram efeito do inoculante sobre FDN e FDA, e com os de RODRIGUES et al. (2001), não encontrando efeito também sobre a LDA. Entretanto, POLAN et al. (1998), que também não observaram efeito do inoculante ou da combinação de inoculante e ácido fórmico sobre o teor de FDA, perceberam diminuição no teor de FDN em todos os tratamentos, comparado ao grupo controle. Neste caso, é possível que o mais baixo $\mathrm{pH}$ das silagens inoculadas tenha promovido hidrólise parcial da hemicelulose. Tais dados discordam dos obtidos por HARRISON et al. (1989) que, utilizando silagens de gramínea e leguminosa, perceberam que houve diminuição da FDA.

O amido também não sofreu efeito do inoculante, discordando dos achados de RODRIGUES et al. (2001), os quais observaram que o inoculante Pioneer $1174^{\circledR}$ aumentou a concentração de amido, enquanto o Sil-All ${ }^{\circledR}$, que possui amilase, diminuiu, quando avaliaram a adição destes inoculantes em silagens de girassol. Entretanto, no presente experimento, as silagens tratadas com inoculante apresentaram tendência de aumento $(\mathrm{P}=0,0645)$ nos teores de carboidratos solúveis em $21,7 \%(0,53$ unidades percentuais), devido possivelmente, a uma maior concentração de bactérias ácido láticas, ao se adicionar o inoculante, que possivelmente melhoraram a eficiência de conversão dos carboidratos solúveis em ácido lático, sem, contudo, aumentar a concentração final deste último. Este achado corrobora com CAI et al. (1999a) e RODRIGUES et al. (2001), que observaram aumento nas concentrações dos carboidratos solúveis, e POLAN et al. (1998), que encontraram aumento em todos os tratamentos, com inoculante microbiano, ácido fórmico ou a combinação destes, 
comparado ao grupo controle. Porém, KUNG et al. (1991b) não encontraram efeito do inoculante sobre esta variável.

A DIVMS também não sofreu efeito do inoculante, concordando com os estudos de KUNG et al. (1991b) e RODRIGUES et al. (2001), os quais concluíram não haver efeito do inoculante sobre a DIVMS, e discordando dos trabalhos de ELY et al. (1981); MADER et al. (1985) e HARRISON et al. (1989), com os quais observaram aumento da DIVMS, comparado ao grupo controle. 
Tabela 1 - Composição bromatológica das silagens pré-secadas de alfafa submetidas ou não à aplicação de inoculante ${ }^{1}$

\begin{tabular}{|c|c|c|c|c|c|}
\hline & \multicolumn{2}{|c|}{ Tratamentos $^{2}$} & \multirow[b]{2}{*}{ Média } & \multirow[b]{2}{*}{ CV } & \multirow[b]{2}{*}{ Prob. } \\
\hline & Controle & Inoculada & & & \\
\hline MS & $51,29^{a}$ & $44,72^{b}$ & 48,01 & 13,20 & 0,0111 \\
\hline PB & 16,38 & 15,90 & 16,14 & 5,38 & NS \\
\hline NIDA & 11,57 & 11,24 & 11,40 & 16,68 & NS \\
\hline NIDN & 14,73 & 16,21 & 15,47 & 13,30 & NS \\
\hline FDN & 46,65 & 47,10 & 46,88 & 8,38 & NS \\
\hline FDA & 39,76 & 40,16 & 39,96 & 10,87 & NS \\
\hline LDA & 11,13 & 10,44 & 10,78 & 12,28 & NS \\
\hline Hemi. & 6,89 & 6,94 & 6,92 & 25,34 & NS \\
\hline Cel. & 28,63 & 29,72 & 29,18 & 11,59 & NS \\
\hline Amido & 0,69 & 0,82 & 0,76 & 45,73 & NS \\
\hline $\mathrm{CHOs}$ & 2,44 & 2,97 & 2,71 & 26,23 & 0,0645 \\
\hline DIVMS & 62,46 & 61,58 & 62,02 & 3,89 & NS \\
\hline
\end{tabular}

MS: matéria seca total (\%); PB: proteína bruta (\% MS); NIDA: nitrogênio insolúvel em detergente ácido ( $\%$ do $\mathrm{N}$ total); NIDN: nitrogênio insolúvel em detergente neutro (\% do $\mathrm{N}$ total); FDN: fibra em detergente neutro (\% MS); FDA: fibra em detergente ácido (\% MS); LDA: lignina em detergente ácido (\% MS); Hemi: hemicelulose (\% MS); Cel: celulose (\% MS); Amido ( $\%$ MS); CHOs: carboidratos solúveis (\% MS); DIVMS: digestibilidade in vitro da matéria seca (\% MS); CV: coeficiente de variação (\%); Prob.: probabilidade estatística; NS: não significativo.

${ }^{2}$ Linhas com letras sobrescritas diferentes diferem estatisticamente (5\%).

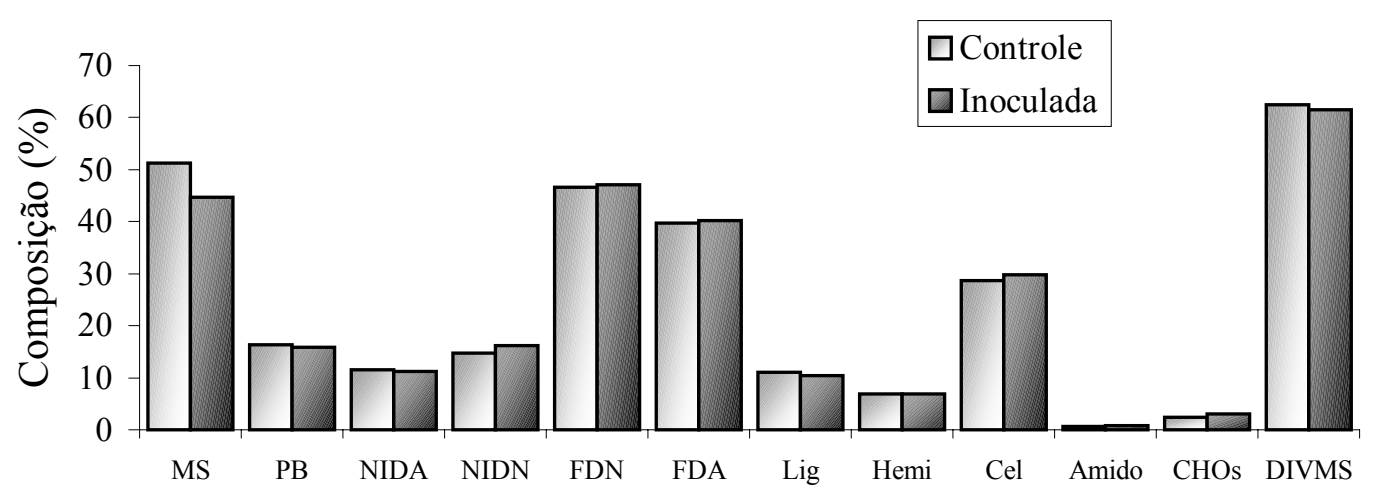

Figura 1 - Composição bromatológica das silagens pré-secadas de alfafa controle e inoculada. 
Os dados de avaliação do perfil fermentativo das silagens submetidas ou não ao tratamento com inoculante encontram-se na Tabela 2. A adição do inoculante à silagem não alterou a concentração de ácido lático (Figura 2) ou a relação lático:acético, podendo a ausência de efeito ser atribuída ao baixo teor de carboidratos solúveis existentes na alfafa, limitando a atividade potencial das bactérias adicionadas em melhorar a qualidade da silagem. Os dados encontrados neste estudo concordam com os achados de ELY et al. (1981); MADER et al. (1985) e POLAN et al. (1998), ao trabalharem com silagem de alfafa, SHOCKEY et al. (1985), ao estudarem silagens de alfafa e milho, SHOCKEY et al. (1988), ao avaliarem silagem de alfafa de baixa qualidade, e RODRIGUES et al. (2001), ao inocularem silagem de girassol, os quais não observaram efeito do inoculante sobre as concentrações de ácido lático. De forma contrária, KUNG et al. (1991b) observaram que o inoculante tendeu em aumentar o ácido lático e CAI et al. (1999a) observaram aumento nas concentrações deste ácido, comparado ao grupo controle, quando estudaram silagens de alfafa, sorgo ou gramínea com 40 dias e tratadas com inoculante microbiano. Em seus estudos, BOLSEN et al. (1992) observaram que a combinação de inoculante e glicose aumentou a concentração de ácido lático na silagem de alfafa de segundo corte, mas este efeito não foi percebido na de quarto corte ou quando utilizaram inoculante microbiano (L. plantarum e $P$. cerevisiae) ou glicose ( $2 \% \mathrm{MS})$, separadamente, nestas silagens, ou somente inoculante (L. plantarum e E. faecium) na silagem de milho. Notaram também que não houve efeito do inoculante sobre outras características de fermentação da silagem de milho ou da silagem de alfafa de quarto corte. Entretanto, CAI et al. (1998) encontraram maior concentração de ácido lático nas silagens inoculadas com cepa homofermentativa, comparado às silagens inoculadas com cepas heterofermentativas e ao grupo controle. 
CAI et al. (1999b) observaram aumento na concentração de ácido lático em silagens na temperatura de $25^{\circ} \mathrm{C}$, em relação ao grupo controle. Porém, na temperatura de $48^{\circ} \mathrm{C}$, somente houve aumento para o tratamento com $P$. acidilactici, quando utilizaram silagens de alfafa e gramínea inoculadas com P. acidilactici, P. pentosaceus ou L. casei.

No presente estudo, a inoculação da silagem aumentou a concentração de ácido acético em 162,9\% (1,5 unidades percentuais) em relação ao grupo controle, mas não alterou as concentrações de etanol e dos ácidos propiônico e butírico (Figura 2). Provavelmente, este efeito sobre o ácido acético possa ser explicado pelo alto poder tampão e alto $\mathrm{pH}$ da silagem de alfafa, não inibindo a ação dos microrganismos produtores deste ácido. Tais dados discordam dos obtidos por SHOCKEY et al. (1988), os quais não observaram efeito do inoculante sobre as concentrações de ácido acético, e dos obtidos por MADER et al. (1985), que também não observaram efeito sobre a concentração deste ácido, embora tivessem notado diminuição nas concentrações dos ácidos propiônico e butírico, comparado ao grupo controle. Entretanto, BOLSEN et al. (1992) perceberam que a combinação de inoculante e glicose diminuiu a concentração de ácido acético, na silagem de alfafa de segundo corte, mas não houve efeito para os tratamentos com inoculante ou glicose separadamente. O inoculante e a combinação diminuíram a concentração de etanol, na silagem de alfafa de segundo corte, porém sem efeito para o tratamento com glicose, em relação ao grupo controle. Também não houve efeito dos tratamentos sobre as concentrações dos ácidos propiônico e butírico, quando RODRIGUES et al. (2001) estudaram a inoculação da silagem de girassol. Porém, estes autores observaram aumento na concentração de etanol e diminuição na de ácido acético. Na inoculação das silagens de alfafa ou gramínea com cepas heterofermentativas e no grupo controle, CAI et al. (1998) obtiveram maior 
concentração de ácido butírico comparando com silagem inoculada com cepa homofermentativa, ocorrendo o mesmo com o ácido acético na silagem de alfafa, mas sem efeito para a silagem de gramínea. CAI et al. (1999b) notaram diminuição na concentração do ácido butírico em silagens na temperatura de $25^{\circ} \mathrm{C}$, em relação ao grupo controle; na temperatura de $48^{\circ} \mathrm{C}$, somente houve diminuição para o tratamento com P. acidilactici e não houve efeito dos inoculantes sobre as concentrações do ácido acético e propiônico.

KUNG et al. (1991b) observaram que o inoculante diminuiu a concentração de ácido acético, o que foi percebido também por CAI et al. (1999a), que observaram ainda diminuição nas concentrações dos ácidos butírico e propiônico, comparado ao grupo controle. Nos achados de POLAN et al. (1998) não foi observado efeito do inoculante sobre a concentração de ácido butírico.

No presente trabalho a concentração de $\mathrm{N}^{-\mathrm{NH}_{3}}$ não foi alterada com a adição do inoculante, estando de acordo com BOLSEN et al. (1992) e POLAN et al. (1998), mas discordando de KUNG et al. (1991b); SHOCKEY et al. (1988); CAI et al. (1999a) e RODRIGUES et al. (2001), os quais observaram diminuição nas concentrações do N$\mathrm{NH}_{3}$. CAI et al. (1999b) observaram diminuição do nitrogênio amoniacal nas silagens tratadas, em relação ao grupo controle, na temperatura de $25^{\circ} \mathrm{C}$; na temperatura de $48^{\circ} \mathrm{C}$, somente houve diminuição para o tratamento com $P$. acidilactici. Tal achado foi confirmado também com o trabalho de CAI et al. (1998), que na inoculação das silagens com cepas heterofermentativas e no grupo controle, obtiveram maior concentração de $\mathrm{N}-\mathrm{NH}_{3}$, comparando com silagem inoculada com cepa homofermentativa.

A adição do inoculante na silagem não teve efeito sobre o $\mathrm{pH}$, corroborando com POLAN et al. (1998); SHOCKEY et al. (1988) e CAI et al. (1999b). Entretanto, KIROV 
(1962); McDONALD et al. (1965); ELY et al. (1981); MADER et al. (1985); KUNG et al. (1991b); CAI et al. (1999a) e RODRIGUES et al. (2001), observaram diminuição do pH, comparado ao grupo controle. Nos estudos de BOLSEN et al. (1992), a combinação de inoculante e glicose diminuiu o $\mathrm{pH}$ da silagem de alfafa de segundo corte, mas não houve efeito para os tratamentos com inoculante ou glicose separadamente, em relação ao grupo controle. $\mathrm{Na}$ inoculação da silagem com cepa homofermentativa, ocorreu um $\mathrm{pH}$ mais baixo, comparando com as silagens inoculadas com cepas heterofermentativas e o grupo controle (CAI et al., 1998). SINGH et al. (1996), ao estudarem a combinação de inoculante e melaço (5\%) na silagem de alfafa, também observaram diminuição do $\mathrm{pH}$.

Um estudo de JONES et al. (1992) mostrou que a redução do pH causada pelo inoculante dobrou com a adição de açúcar em silagem de alfafa com 70\% de umidade, mas com 50\%, a adição de açúcar não alterou o desempenho do inoculante. Estes resultados sugerem que o teor de umidade e de açúcar da silagem de alfafa pode limitar a eficiência dos inoculantes.

Associada à ausência de efeito do inoculante sobre a produção dos ácidos orgânicos da silagem, também não se observou efeito sobre o poder tampão, discordando de RODRIGUES et al. (2001), os quais encontraram aumento do poder tampão, quando utilizaram o inoculante Pioneer $1174^{\circledR} \mathrm{em}$ silagem de girassol.

É possível que a adequada fermentação obtida na silagem controle aqui estudada, e demonstrada pelos teores dos ácidos lático e butírico e da relação lático:acético, adivindas provavelmente do processo de pré-secagem, tenha inibido os ganhos que poderiam ocorrer com a inoculação. 
Tabela 2 - Fermentação das silagens pré-secadas de alfafa submetidas ou não à aplicação de inoculante ${ }^{1}$

\begin{tabular}{|c|c|c|c|c|c|}
\hline & \multicolumn{2}{|c|}{ Tratamentos $^{2}$} & \multirow[b]{2}{*}{ Média } & \multirow[b]{2}{*}{$\mathrm{CV}$} & \multirow[b]{2}{*}{ Prob. } \\
\hline & Controle & Inoculada & & & \\
\hline Etanol & 0,024 & 0,018 & 0,021 & 71,50 & $\mathrm{NS}$ \\
\hline Acético & $0,894^{\mathrm{b}}$ & $2,351^{\mathrm{a}}$ & 1,623 & 96,73 & 0,0479 \\
\hline Prop. & 0,000 & 0,000 & 0,000 & 0,000 & NS \\
\hline Butírico & 0,000 & 0,000 & 0,000 & 0,000 & NS \\
\hline Lático & 4,448 & 5,620 & 5,034 & 32,04 & NS \\
\hline Rel Lat:Ace & 4,868 & 4,574 & 4,721 & 48,11 & NS \\
\hline $\mathrm{N}-\mathrm{NH}_{3}$ & 5,21 & 8,19 & 6,70 & 226,32 & NS \\
\hline $\mathrm{pH}$ & 5,33 & 4,96 & 5,14 & 8,87 & NS \\
\hline PT & 51,73 & 52,90 & 52,32 & 12,09 & NS \\
\hline
\end{tabular}

${ }^{1}$ Etanol (\% MS); Acético (\% MS); Prop.: propiônico (\% MS); Butírico (\% MS); Lático (\% MS); Rel Lat:Ace: relação lático:acético; $\mathrm{N}^{-\mathrm{NH}_{3}}$ : nitrogênio amoniacal $(\%$ do $\mathrm{N}$ total); PT: poder tampão (meq./100g MS de forragem); CV: coeficiente de variação (\%); Prob.: probabilidade estatística; NS: não significativo.

${ }^{2}$ Linhas com letras sobrescritas diferentes diferem estatisticamente (5\%).

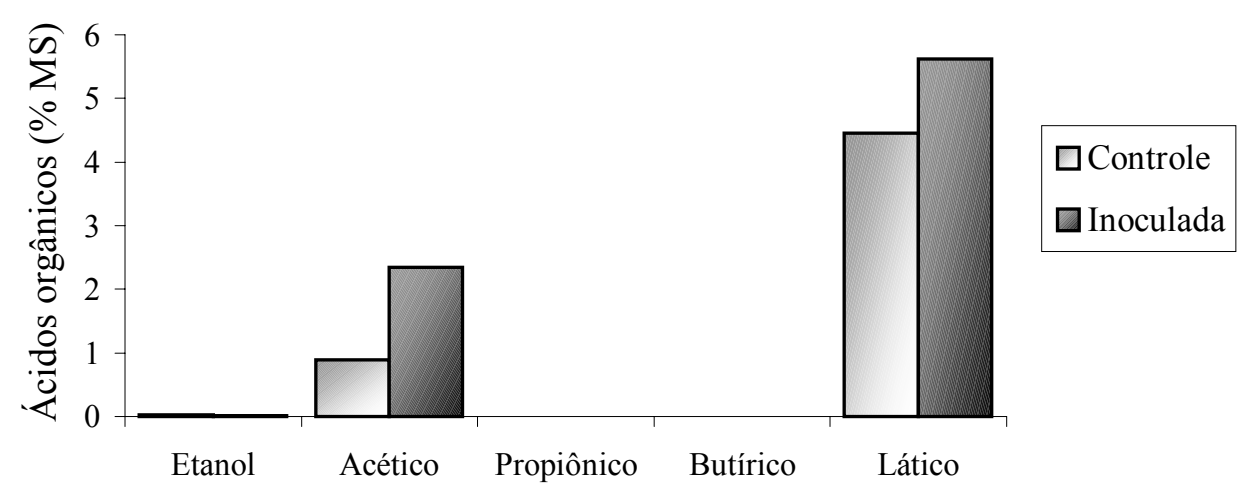

Figura 2 - Porcentagem de ácidos orgânicos nas silagens pré-secadas de alfafa controle e inoculada. 
Os dados de estabilidade aeróbia das silagens submetidas ou não ao tratamento com inoculante encontram-se na Tabela 3. O inoculante não provocou efeito sobre o tempo para alcançar a máxima temperatura, sobre a temperatura máxima alcançada ou sobre a taxa de elevação da temperatura, concordando com os estudos de CAI et al. (1999a) e RODRIGUES et al. (2001), que também não encontraram efeito do inoculante sobre a estabilidade aeróbia. KUNG et al. (1991a) observaram ainda uma tendência em diminuir a estabilidade aeróbia, comparado ao grupo controle, quando aplicaram a combinação de inoculante mais antibiótico. Em alguns estudos (MERRY e BRAITHWAITE, 1987; PITT, 1990 e POLAN et al., 1998) a adição de bactérias ácido láticas também diminuiu a estabilidade aeróbia da silagem.

Segundo WOOLFORD (1984), a elevação da tensão osmótica dificulta o desenvolvimento de microrganismos indesejáveis. Assim, a estabilidade fermentativa é obtida com pH mais elevado (HAIGH, 1990).

A deterioração aeróbia de silagens inoculadas está associada com altas concentrações de carboidratos solúveis residuais e de ácido lático, bem como à ausência de ácidos graxos voláteis (KUNG et al., 1991b). A maioria das cepas de leveduras isoladas de silagens deterioradas possuem alta tolerância ao ácido lático, mas baixa tolerância ao ácido butírico. Estas leveduras são capazes de crescer em condições de pH baixo e de utilizar ácido lático e carboidratos solúveis para o seu crescimento, mas são inibidas por baixas concentrações de ácido butírico e propiônico (HOGAN et al., 1990). Portanto, relativamente, altas concentrações de ácido butírico, propiônico e acético na silagem podem causar uma melhor estabilidade aeróbia.

E ainda, de acordo com MUCK e KUNG (1997), o aumento nas concentrações de ácido acético, mais a redução de fungos e leveduras no início da fermentação da 
silagem, trabalhariam juntos para uma melhor estabilidade aeróbia após a abertura do silo.

Embora tenha aumentado as concentrações de ácido acético no presente estudo, os inoculantes não melhoram a estabilidade aeróbia, provavelmente, por esta já se encontrar adequada.

Tabela 3 - Estabilidade aeróbia das silagens pré-secadas de alfafa submetidas ou não à aplicação de inoculante ${ }^{1}$

\begin{tabular}{|c|c|c|c|c|c|}
\hline & \multicolumn{2}{|c|}{ Tratamentos } & \multirow[b]{2}{*}{ Média } & \multirow[b]{2}{*}{$\mathrm{CV}$} & \multirow[b]{2}{*}{ Prob. } \\
\hline & Controle & Inoculada & & & \\
\hline Tempo & 61,09 & 58,91 & 60,00 & 50,52 & NS \\
\hline Max.. & 24,30 & 23,78 & 24,04 & 3,02 & NS \\
\hline Taxa & 0,023 & 0,023 & 0,023 & 124,96 & NS \\
\hline
\end{tabular}

${ }^{1}$ Tempo: tempo decorrido para alcançar a máxima temperatura (horas); Max.: máxima temperatura alcançada $\left({ }^{\circ} \mathrm{C}\right)$; Taxa: taxa de elevação da temperatura $\left({ }^{\circ} \mathrm{C} / \mathrm{hora}\right) ; \mathrm{CV}$ : coeficiente de variação (\%); Prob.: probabilidade estatística; NS: não significativo.

Os dados de escore de bolor das silagens submetidas ou não ao tratamento com inoculante encontram-se na Tabela 4. Observou-se tendência de efeito de interação $(\mathrm{P}=0,0594)$ entre tratamento e profundidade de avaliação. Ao se avaliar efeito de tratamento em cada profundidade, observou-se que as silagens inoculadas apresentaram uma tendência de diminuição do escore de bolor em 45,5\% (20,9 unidades percentuais) na profundidade de $10 \mathrm{~cm}$, em relação ao grupo controle, embora o inoculante não tivesse causado efeito nas profundidades de $30 \mathrm{~cm}$ e $50 \mathrm{~cm}$ (Figura 1). KUNG et al. (1991b) também observaram que o inoculante tendeu em diminuir a porcentagem de 
bolor, comparado ao grupo controle, enquanto que BOLSEN et al. (1992), estudando silagens de alfafa de segundo e quarto cortes tratadas com inoculante (L. plantarum e P. cerevisiae), glicose (2\% MS) ou a combinação de ambos, não notaram efeito do inoculante sobre as mesmas. Na silagem de milho tratada somente com inoculante $(L$. plantarum e E. faecium), esses autores também não perceberam efeito. POLAN et al. (1998), trabalhando com silagem de alfafa vaporizada e adicionada de inoculante microbiano, ácido fórmico ou a combinação de ambos, notificaram que a combinação diminuiu o emboloramento das silagens, comparado à adição separada do ácido fórmico ou inoculante.

Na profundidade de $10 \mathrm{~cm}$ o material se encontra mais exposto à penetração de oxigênio, permitindo o maior desenvolvimento de bolores. É possível que a maior concentração de ácido acético encontrada na silagem inoculada tenha inibido o crescimento de bolor nessa profundidade, mas não a 30 ou $50 \mathrm{~cm}$, onde o escore de bolor já foi naturalmente mais baixo.

Tabela 4 - Escore de bolor das silagens pré-secadas de alfafa submetidas ou não à aplicação de inoculante ${ }^{1}$

\begin{tabular}{|c|c|c|c|c|c|}
\hline \multirow[b]{2}{*}{ Profundidade } & \multicolumn{2}{|c|}{ Tratamentos } & \multirow[b]{2}{*}{ Média } & \multirow[b]{2}{*}{$\mathrm{CV}$} & \multirow[b]{2}{*}{ Prob. } \\
\hline & Controle & Inoculada & & & \\
\hline 10 & 45,91 & 25,00 & 35,45 & 87,03 & 0,0750 \\
\hline 30 & 11,36 & 9,09 & 10,23 & 111,36 & NS \\
\hline 50 & 7,27 & 6,36 & 6,82 & 170,18 & NS \\
\hline Média & 21,52 & 13,48 & 17,50 & 135,06 & NS \\
\hline
\end{tabular}

Profundidade: $10 \mathrm{~cm}, 30 \mathrm{~cm}$ e $50 \mathrm{~cm}$, onde se avaliou a porcentagem de área embolorada presente na silagem; CV: coeficiente de variação (\%); Prob.: probabilidade estatística; NS: não significativo. 


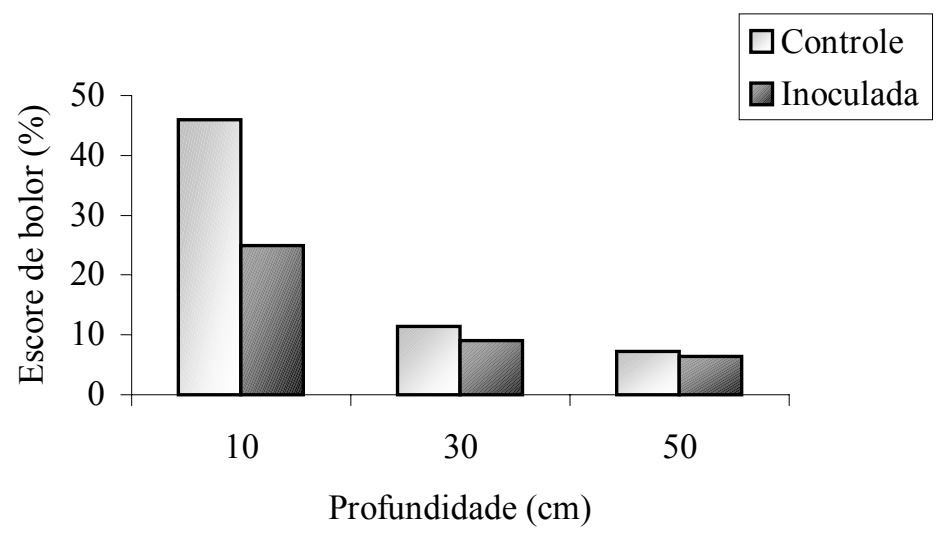

Figura 3 - Escore de bolor das silagens pré-secadas de alfafa controle e inoculada nas profundidades de $10 \mathrm{~cm}, 30 \mathrm{~cm}$ e $50 \mathrm{~cm}$.

\section{Conclusões}

Com base nas observações do presente estudo, não é possível recomendar a utilização do produto Silobac ${ }^{\circledR}$ na inoculação da silagem pré-secada de alfafa, uma vez que nenhum efeito benéfico foi observado sobre a composição bromatológica, perfil fermentativo ou estabilidade aeróbia das silagens.

Entretanto, é possível que uma pequena melhora no aspecto visual externo da silagem seja notado pelos produtores. 


\section{Referências Bibliográficas}

ASSOCIATION OF OFFICIAL ANALYTICAL CHEMISTS - AOAC. Official methods of analysis. 10. ed. Washington, D.C.: Association of Analytical Chemistry. 1980. $1015 \mathrm{p}$.

BOLSEN, K. K.; LIN, C.; BRENT, B. E.; FEYERHERM, A. M.; URBAN, J. E.; AIMUTIS, W. R. Effect of silage additives on the microbial succession and fermentation process of alfalfa and corn silages. J. Dairy Sci., v. 75, n. 11, p. 30663083, 1992.

CAI, Y.; BENNO, Y.; OGAWA, M.; KUMAI, S. Effect of applying lactic acid bacteria isolated from forage crops on fermentation characteristics and aerobic deterioration of silage. J. Dairy Sci., v. 82, n. 3, p. 520-526, 1999a.

CAI, Y.; BENNO, Y.; OGAWA, M.; OHMOMO, S.; KUMAI, S.; NAKASE, T. Influence of Lactobacillus spp. from an inoculant and of Weissela and Leuconostoc spp. from forage crops on silage fermentation. Appl. Environ. Microbiol., v. 64, n. 8, p. 2982-2987, 1998.

CAI, Y.; KUMAI, S.; OGAWA, M.; BENNO, Y.; NAKASE, T. Characterization and identification of Pediococcus species isolated from forage crops and their application for silage preparation. Appl. Environ. Microbiol., v. 65, n. 7, p. 2901-2906, 1999b.

CARR, S. B.; HAMMES JUNIOR, R. C.; MOE, A. J.; McGILliARD, M. L. Corn silage preservation with anhydrous ammonia, live culture microbial, or organic acidbased additives. J. Dairy Sci., v. 67, n. 7, p. 1474-1481, 1984.

CLEALE, R. M.; FIRKINS, J. L.; VAN DER BEEK, F.; CLARK, J. H.; JASTER, E. H.; McCOY, G. C.; KLUSMEYER, T. H. Effect of inoculation of whole plant corn forage with Pediococcus acidilactici and Lactobacillus xylosus on preservation of silage and heifer growth. J. Dairy Sci., v. 73, n. 3, p. 711-718, 1990.

ELY, L. O.; MOON, N. J.; SUDWEEKS, E. M. Chemical evaluation of Lactobacillus addition to alfalfa, corn, sorghum, and wheat forage at ensiling. J. Dairy Sci., v. 65, n. 6, p.1041-1046, 1982.

ELY, L. O.; SUDWEEKS, E. M.; MOON, N. J. Inoculation with Lactobacillus plantarum of alfalfa, corn, sorghum, and wheat silages. J. Dairy Sci., v. 64, n. 12, p. 2378-2387, 1981.

ERWIN, E. S.; MACCO, G. J.; EMERY, E. M. Volatile fatty acid analyses of blood and rumen fluid by gas chromatography. J. Dairy Sci., v. 44, n. 9, p. 1768-1771, 1961.

FOLDAGER, J. Protein requeriment and non protein nitrogen for high producing cow in early lactation. 1977. 167 f. Tese (Doutorado em Ciência Animal) - Michigan State University, East Lasing, 1977. 
HAIGH, P. M. Effect of herbage water-soluble carohydrate content and weather conditions at ensilage on the fermentation of grass silages made on commercial farms. Grass Forage Sci., v. 45, n.3, p. 263-271, 1990.

HARRISON, J. H.; SODERLUND, S. D.; LONEY, K. A. Effect of inoculation rate of selected strains of lactic acid bacteria on fermentation and in vitro digestibility of grasslegume forage. J. Dairy Sci., v. 72, n. 9, p. 2421-2426, 1989.

HENDRIX, D. L. Rapid extraction and analysis of nonstructural carbohydrates in plant tissues. Crop Sci., v. 33, n. 6, p. 1306-1311, 1993.

HOGAN, C. M.; MES HARTREE, M.; SADDLER, J. N.; KUSHNER, D. J. Assessment of methods to determine minimal cellulase concentrations for efficient hydrolysis of cellulose. Appl. Microbiol. Biotechnol., v. 32, n. 5, p. 614-620, 1990.

JOHNSON, R. R.; BALWANI, T. L.; JOHNSON, L. J.; McClURE, K. E.; DEHORITY, B. A. Corn plant maturity. II. Effect on in vitro cellulose digestibility and soluble carabohydrate content. J. Anim. Sci., v. 25, n. 3, p. 617-623, 1966.

JONES, B. A.; SATTER, L. D.; MUCK, R. E. Influence of bacterial inoculant and substrate addition to lucerne ensiled at different dry matter contents. Grass Forage Sci., v. 47, n.1, p.19-27, 1992.

KIROV, N. A study of the effects of bacterial ferments on quality of silages made from forage easy and difficult to ensile. Naucn. Tr. Viss. Selskostop, v. 1, n. 1, p. 363-367, 1962.

KUNG JUNIOR, L.; GRIEVE, D. B.; THOMAS, J. W.; HUBER, J. T. Added ammonia or microbial inocula for fermentation and nitrogenous compounds of alfalfa ensiled at various percents of dry matter. J. Dairy Sci., v. 67, n. 2, p. 299-306, 1984.

KUNG JUNIOR, L.; TUNG, R. S.; MACIOROWSKI, K. G. Effect of a microbial inoculant (Ecosyl TM) and/or a glycopeptide antibiotic (vancomycin) on fermentation and aerobic stability of wilted alfalfa silage. Anim. Feed Sci. Technol., v. 35, n. 1, p. 37-48, 1991a.

KUNG JUNIOR, L.; TUNG, R. S.; MACIOROWSKI, K. G.; BUFFUM, K.; KNUTSEN, K.; AIMUTIS, W. R. Effects of plant cell-wall-degrading enzymes and lactic acid bacteria on silage fermentation and composition. J. Dairy Sci., v. 74, n. 12, p. 4284-4296, $1991 b$.

LINDGREN, S.; KASPERSSON, A.; RYDBERG, E.; LINGVALL, P.; KARTZOW, A. Effect of inoculants, grain, and formic acid on silage fermentation. Swed. J. Agric. Res., v. 13, n. 2, p. 91-100, 1983.

MADER, T. L.; BRITTON, R. A.; KRAUSE, V. E.; PANKASKIE, D. E. Effect of additive on alfalfa silage fermentation characteristics and feedlot performance of steers. J. Dairy Sci., v. 68, n. 7, p. 1744-1747, 1985. 
McAlLISTER, T. A.; FENIUK, R.; MIR, Z.; MIR, P.; SELINGER, L. B.; CHENG, K. J. Inoculants for alfalfa silage: effects on aerobic stability, digestibility and the growth performance of feedlot steers. Livest. Prod. Sci., v. 53, n. 2, p. 171-181, 1998.

McDONALD, P.; HENDERSON, A. R. Buffering capacity of herbage samples as a factor in ensilage. J. Sci. Food Agric., v. 13, n.3, p. 395-400, 1962.

McDONALD, P.; STIRLING, A. C.; HENDERSON, A. R.; WHITTENBURY, R. Fermentation studies on red clover. J. Sci. Food Agric., v.16, n. 5, p. 549-557, 1965.

MERRY, R. J.; BRAITHWAITE, G. D. The effect of enzymes and inoculants on the chemical and microbiological composition of grass legume silages. In: SILAGE CONFERENCE, 8., 1987, Hurley. Proceedings... Hurley: Institute for Grassland and Animal Production. 1987. p. 27.

MIR, Z.; JAN, E. Z.; ROBERTSON, J. A.; MIR, P. S.; McCARTNEY, D. H. Effects of microbial inoculant and moisture content on preservation and quality of round baled alfalfa. Can. J. Anim. Sci., v. 75, n. 1, p. 15-23, 1995.

MOON, N. J.; ELY, L. O.; SUDWEEKS, E. M. Fermentation of wheat, corn, and alfalfa silages inoculated with Lactobacillus acidophilus and Candida sp. at ensiling. J. Dairy Sci., v. 64, n. 5, p. 807-813, 1981.

MUCK, R. E. Initial bacterial numbers on lucerne prior to ensiling. Grass Forage Sci., v. 44, n. 1, p. 19-25, 1989.

MUCK, R. E.; KUNG JUNIOR, L. Effects of silage additives on ensiling. In: SILAGE: FIELD TO FEEDBUNK NORTH AMERICA CONFERENCE, 1997, Hershey. Proceedings... Hershey: NRAES, 1997. p. 187-199.

MULLER, T.; FEHRMANN, E.; SEYFARTH, W.; KNABE, O. Quality of grass silage depending on epiphytic lactic acid bacteria. In: FORAGE CONSERVATION TOWARDS 2000, 123., 1991, Braunschweig. Proceedings... Braunschweig: Landbauforschung Voelkenrode Sonderheft, 1991. p. 297.

PEREIRA, J. R. A.; ROSSI JÚNIOR, P. Manual prático de avaliação nutricional de alimentos. 1. ed. Piracicaba: FEALQ, 1995. 25 p.

PITT, R. E. A model of cellulase and amylase additives in silage. J. Dairy Sci., v. 73, n. 7, p.1788-1799, 1990.

POLAN, C. E.; STIEVE, D. E.; GARRETT, J. L. Protein preservation and ruminal degradation of ensiled forage treated with heat, formic acid, ammonia, or microbial inoculant. J. Dairy Sci., v. 81, n. 3, p. 765-776, 1998. 
RODRIGUES, P. H. M.; ALMEIDA, T. F.; MELOTTI, L.; ANDRADE, S. J. T.; PEIXOTO JÚNIOR, K. C. Efeitos da adição de inoculantes microbianos sobre a composição bromatológica e sobre a fermentação da silagem de girassol produzida em silos experimentais. Rev. Bras. Zootec., v. 30, p. 2169-2175, 2001. Supplement, 6.

RUPPEL, K. A.; PITT, R. E.; CHASE, L. E.; GALTON, D. M. Bunker silo management and its relationship to forage preservation on dairy farms. J. Dairy Sci., v. 78, n. 1, p. 141-153, 1995.

SAS Institute. SAS user's guide: statistics. 7. ed. Cary, NC: SAS Institute, 1998.

SHOCKEY, W. L.; DEHORITY, B. A.; CONRAD, H. R. Effects of microbial inoculant on fermentation of alfalfa and corn. J. Dairy Sci., v. 68, n. 11, p. 3076-3080, 1985.

SHOCKEY, W. L.; DEHORITY, B. A.; CONRAD, H. R. Effects of microbial inoculant on fermentation of poor quality alfalfa. J. Dairy Sci., v. 71, n. 3, p. 722-726, 1988.

SINGH, A.; EDWARD, J. C.; MOR, S.; SINGH, K. Biochemical changes during ensiling of wilted lucerne with inoculation of lactic acid bacteria and molasses. Indian J. Anim. Nutrition, v. 13, n. 2, p. 77-82, 1996.

SPECKMAN, C. A.; PHILIPS, R. M.; LINNERTZ, D. P.; BERGER, J. C. A.; CARVER, L. A.; PARKER, R. B. A survey for indigenous Lactobacillus species on standing field corn at ensiling maturity. J. Anim. Sci., v. 53, p. 99, 1981. Supplement, 1.

TILLEY, J. M. A.; TERRY, R. A. A two-stage technique for the in vitro digestion of forage crops. J. Br. Grassl. Soc., v. 18, n. 2, p. 104-111, 1963.

TOSI, H. Conservação de forragem como conseqüência do manejo. In: SIMPÓSIO SOBRE MANEJO DE PASTAGENS, 1., 1973, Piracicaba. Anais... Piracicaba: FEALQ, 1973. p. 117-140.

VAN SOEST, P. J. Development of a comprehensive system for analysis and its application to forage. J. Dairy Sci., v. 26, n. 1, p. 119-128, 1967.

VAN SOEST, P. J.; ROBERTSON, J. B. Analysis of forages and fibrous foods. 1. ed. Ithaca: Cornell University, 1985. 202 p.

WOOLFORD, M. K. The silage fermentation. New York: Marcel Dekker, 1984. 350 p.

ZAGO, C. P. Cultura de sorgo para a produção de silagem de alto valor nutritivo. In: SIMPÓSIO SOBRE NUTRIÇÃO DE BOVINOS, 4., 1991, Piracicaba. Anais... Piracicaba: FEALQ, 1991. p. 169-213. 


\section{CAPÍTULO IV}

\section{INOCULAÇÃO MICROBIANA DA SILAGEM PRÉ-SECADA DE ALFAFA SOBRE A DIGESTIBILIDADE APARENTE EM VACAS LEITEIRAS}

RESUMO - O objetivo do presente estudo foi avaliar os efeitos da inoculação microbiana da silagem pré-secada de alfafa sobre a digestibilidade aparente em doze vacas leiteiras, multíparas, distribuídas em delineamento em reversão simples com seqüência balanceada ("cross-over") com dois períodos sucessivos. Os tratamentos corresponderam a silagem pré-secada de alfafa (50,0\% de MS e 16,5\% de PB) controle ou inoculada com o produto Silobac ${ }^{\circledR}$ (Lactobacillus plantarum e Pediococcus pentosaceus). Cada período experimental teve duração de 21 dias, sendo os cinco últimos dias destinados à coleta de fezes. O inoculante aumentou a digestibilidade aparente da MS (inoculada $=81,7$ vs. controle $=74,2 \%)$, PB (83,1 vs. 74,6\%), EE $(90,1$ vs. $81,7 \%$ ), ENN ( 84,1 vs. $78,7 \%$ ), FB ( 74,8 vs. $61,9 \%$ ), FDN (70,0 vs. $58,0 \%$ ), FDA $(75,2$ vs. $63,9 \%)$, amido $(92,7$ vs. $88,9 \%)$, EB ( 82,4 vs. $74,7 \%)$ e o NDT ( 80,5 vs. $73,3 \%$ ), em relação ao grupo controle. Porém, não houve efeito do inoculante sobre o consumo MS digestível (14,5 vs. 13,3 kg/animal/dia, ou 2,67 vs. $2,46 \%$ do PV) ou de NDT (14,3 vs. $13,2 \mathrm{~kg} /$ animal/dia ou 2,63 vs. $2,43 \%$ do PV).

Palavras-chave: bactérias láticas, bovinos, digestibilidade, ensilagem, Medicago sativa 


\title{
MICROBIAL INOCULATION OF ALFALFA HAYLAGE ON APPARENT DIGESTIBILITY IN DAIRY COWS
}

\begin{abstract}
The objective of this study was to evaluate the effects of microbially inoculated alfalfa haylage on apparent digestibility in twelve dairy cows. A cross-over design with two periods of sampling was used. Treatments were alfalfa haylage $(50.0 \% \mathrm{DM}$ and $16.5 \% \mathrm{CP})$ control or microbially inoculated with Silobac ${ }^{\circledR}$ product (Lactobacillus plantarum and Pediococcus pentosaceus). Each experimental period extended for twenty-one days, the last five used for feces sampling. The inoculation increased apparent digestibility of DM (inoculated $=81.7$ vs. control $=$ $74.2 \%)$, CP (83.1 vs. $74.6 \%$ ), EE (90.1 vs. $81.7 \%$ ), NFE (84.1 vs. $78.7 \%)$, CF (74.8 vs. $61.9 \%)$, NDF (70.0 vs. 58.0\%), ADF (75.2 vs. 63.9\%), starch (92.7 vs. $88.9 \%)$, GE (82.4 vs. $74.7 \%)$ and TDN (80.5 vs. $73.3 \%$ ) compared to control. However, it did not influence digestible DMI (14.5 vs. $13.3 \mathrm{~kg} / \mathrm{animal} /$ day or $2.67 \mathrm{vs.} 2.46 \%$ of BW), nor TDN (14.3 vs. $13.2 \mathrm{~kg} / \mathrm{animal} /$ day or 2.63 vs. $2.43 \%$ of BW).
\end{abstract}

Keywords: cattle, digestibility, ensilage, lactic acid bacteria, Medicago sativa 


\section{Introdução}

A alfafa possui um alto conteúdo protéico, baixo conteúdo de carboidratos solúveis e alto poder tampão, sendo menos apta à sofrer uma boa fermentação, podendo, com isso, sofrer maior proteólise durante o processo de ensilagem (McDONALD et al., 1991), mesmo com um desenvolvimento rápido e completo das condições anaeróbias (POLAN et al., 1998).

Portanto, durante a fermentação da silagem pode haver o crescimento de muitos microrganismos indesejáveis, causando perdas de matéria seca, aquecimento e assim diminuindo a qualidade da silagem. Os inoculantes microbianos, que contém bactérias acido láticas, auxiliam na preservação dos nutrientes com a produção de ácido lático, causando rápida diminuição do $\mathrm{pH}$, e sendo a silagem um meio anaeróbio, o crescimento destes microrganismos é interrompido (MUCK, 2000).

Apesar da inoculação da silagem de alfafa produzir efeitos variados (BOLSEN et al., 1989), uma melhora na eficiência fermentativa com redução das perdas de matéria seca foram observadas, resultando em melhora na digestibilidade dos nutrientes (RICE et al., 1990) e ocorrendo aumento no consumo de matéria seca, no ganho de peso diário e na eficiência alimentar (McALLISTER et al., 1998).

Foram objetivos do presente estudo avaliar a influência da inoculação microbiana, com o produto Silobac ${ }^{\circledR}$, sobre a digestibilidade aparente in vivo da silagem pré-secada de alfafa e o consumo de matéria seca digestível e de nutrientes digestíveis totais por vacas leiteiras. 


\section{Material e Métodos}

O trabalho foi conduzido nas dependências do Departamento de Nutrição e Produção Animal da Faculdade de Medicina Veterinária e Zootecnia da Universidade de São Paulo (Campus de Pirassununga).

A cultura de alfafa foi cortada em dezembro de 2000, quando em estádio do meio do florescimento. Após colhido e pré-seco por quatro horas, o material original foi acondicionado em fardos com aproximadamente $150 \mathrm{~cm}$ de altura e $150 \mathrm{~cm}$ de diâmetro (capacidade de 600 quilos), revestidos com película de PVC branca. Os silos foram divididos em dois tratamentos, um controle e outro com adição do inoculante comercial Silobac $^{\circledR}$ (Chr. Hansen Indústria e Comércio Ltda.), segundo as recomendações do fabricante. De acordo com essas recomendações, o produto fornece 1,0 x $10^{5}$ unidades formadoras de colônia (Lactobacillus plantarum e Pediococcus pentosaceus) por grama de forragem. O inoculante comercial Silobac ${ }^{\circledR}$ foi escolhido em função de melhores resultados obtidos ao avaliar os inoculantes Sil-All ${ }^{\circledR}$ (Alltech do Brasil Agroindustrial Ltda.), Pioneer $1174^{\circledR}$ (Pioneer Sementes Ltda.) e Silobac ${ }^{\circledR}$ em ensaios fermentativos com cultura de alfafa ensilada em silos experimentais (resultados não publicados).

Aproximadamente $600 \mathrm{~kg}$ de massa úmida foram colocadas em cada silo, correspondendo a uma compactação de aproximadamente $230 \mathrm{~kg}$ de silagem $/ \mathrm{m}^{3}$. Os silos foram mantidos fechados por 40 dias expostos às intempéries.

Para o ensaio de digestão aparente foram utilizadas 12 vacas Holandesas, com $135 \pm 16,4$ dias de lactação, alojadas em baias individuais presas por corrente (sistema tie-stall). O delineamento experimental foi de reversão simples com seqüência balanceada ("cross-over") com dois períodos de coletas, e os tratamentos compostos 
pelas silagens controle ou inoculada na proporção $50 \%$ de concentrados e $50 \%$ de volumosos na dieta (Tabela 1 e 2). A ração foi fornecida em duas refeições, às 8:00 e 16:00 horas, sendo a silagem oferecida juntamente com o concentrado, permitindo-se $15 \%$ de sobras.

Tabela 1 - Composição bromatológica das silagens pré-secadas de alfafa controle e inoculada (porcentagem com base na MS)

\begin{tabular}{lcccccccccc}
\hline Silagem & MS & PB & EE & MM & FB & FDN & FDA & Amido & Ca & P \\
\hline Controle & 51,96 & 16,58 & 1,76 & 11,44 & 30,82 & 47,72 & 40,34 & 1,36 & 0,83 & 0,31 \\
Inoculada & 47,48 & 16,32 & 2,00 & 11,85 & 31,34 & 46,10 & 40,93 & 0,92 & 0,79 & 0,33 \\
\hline
\end{tabular}

A Tabela 2 mostra as rações utilizadas e os resultados das análises bromatológicas das mesmas. 
Tabela 2 - Proporções de ingredientes utilizados e composição bromatológica das rações, com base na matéria seca

\begin{tabular}{lcc}
\hline \multirow{2}{*}{ Ingredientes (\%) } & \multicolumn{2}{c}{ Tratamentos } \\
\cline { 2 - 3 } Silagem de alfafa & Controle & Inoculada \\
Silagem de alfafa inoculada & 50,0 & - \\
Grãos de milho moído & - & 50,0 \\
Grãos de soja extrusados & 40,5 & 40,5 \\
Calcário calcítico & 7,5 & 7,5 \\
Sal branco & 0,10 & 0,10 \\
Mistura mineral ${ }^{1}$ & 0,63 & 0,63 \\
& 1,21 & 1,21 \\
\hline \multicolumn{1}{c}{ Composição } & 100,00 & 100,00 \\
\hline MS (\%) & & \\
PB (\%) & 65,4 & 61,7 \\
Proteína degradável (\%) & 15,8 & 15,7 \\
Proteína não degradável (\%) & 10,7 & 10,6 \\
FDA (\%) & 5,1 & 5,1 \\
FDN (\%) & 22,3 & 22,6 \\
EE (\%) & 28,8 & 28,0 \\
Energia Líq. Lact. (Mcal/kg) & 2,7 & 2,8 \\
Ca (\%) & 1,53 & 1,53 \\
P (\%) & 0,70 & 0,70 \\
\hline Composic̃a por kg de & 0,40 & 0,50 \\
\hline
\end{tabular}

${ }^{\mathrm{T} C o m p o s i c ̧ a ̃ o ~ p o r ~ k g ~ d e ~ m i s t u r a ~ m i n e r a l: ~} 180 \mathrm{~g} \mathrm{Ca}, 90 \mathrm{~g} \mathrm{P}, 20 \mathrm{~g} \mathrm{Mg}$, $20 \mathrm{~g} \mathrm{~S}, 100 \mathrm{~g} \mathrm{Na}, 3.000 \mathrm{mg} \mathrm{Zn}, 1.000 \mathrm{mg} \mathrm{Cu}, 1.250 \mathrm{mg} \mathrm{Mn}, 2.000 \mathrm{mg}$ Fe, 200mg Co, 90mg I, 36mg Se, 900mg F (máximo).

O experimento teve duração total de 42 dias, sendo 21 dias para cada período, dos quais os primeiros 16 dias foram destinados à adaptação dos animais às dietas. Nos cinco últimos dias foram realizadas mensurações do consumo e coleta de fezes para avaliação da digestibilidade in vivo. Para comporem uma amostra final, alimentos e fezes foram amostrados duas vezes ao dia, próximos às refeições, sendo a de fezes realizada diretamente do reto.

A digestibilidade in vivo da matéria seca (MS) da dieta e suas frações, como proteína bruta $(\mathrm{PB})$, extrato etéreo $(\mathrm{EE})$, extrativos não nitrogenados $(\mathrm{ENN})$, fibra bruta (FB), fibra em detergente neutro (FDN), fibra em detergente ácido (FDA), energia bruta 
(EB) e amido, foram avaliadas através do marcador cinzas insolúveis em detergente ácido (CIDA), segundo metodologia utilizada por CARVALHO et al. (1992).

As análises bromatológicas de $\mathrm{MS}, \mathrm{PB}, \mathrm{EE}, \mathrm{FB}, \mathrm{EB}$, matéria mineral (MM), amido, cálcio (Ca) e fósforo (P) foram realizadas segundo AOAC (1980), e de FDN e FDA segundo GOERING e VAN SOEST (1979). Para a análise de FDN foi omitido o sulfito de sódio, mas adicionada a $\alpha$-amilase.

Os resultados foram analisados através do programa computacional Statistical Analysis System (SAS Institute Inc., 1998). Os dados foram submetidos à análise de variância através do PROC GLM (General Linear Models). O modelo estatístico separou como causas de variação efeito de tratamento e período. Foi utilizado o nível de significância de 5\% para todos os testes realizados.

\section{Resultados e Discussão}

Os dados de digestibilidade aparente da matéria seca da dieta, e suas frações, dos animais submetidos à silagem controle e inoculada encontram-se na Tabela 3.

A adição de inoculante à silagem de alfafa aumentou a digestibilidade aparente da MS em 10,1\% (7,5 unidades percentuais), PB em 11,4\% (8,5 unidades percentuais), EE em 10,3\% (8,4 unidades percentuais), ENN em 6,8\% (5,4 unidades percentuais), FB em 21,0\% (13,0 unidades percentuais), FDN em 20,8\% (12,0 unidades percentuais), FDA em 17,7\% (11,3 unidades percentuais), amido em 4,2\% (3,7 unidades percentuais), EB em 10,4\% (7,7 unidades percentuais) e o NDT em 9,8\% (7,2 unidades percentuais), como pode ser observado na Figura 1.

Os resultados do presente experimento concordam com aqueles observados por MADER et al. (1985), que demonstraram aumento da digestibilidade in vitro da MS da 
silagem de alfafa inoculada, MAYNE (1990), o qual sugeriu aumento da digestibilidade da MS em carneiros, ao adicionar inoculante microbiano (L. plantarum) em silagem de gramínea, e MAYNE (1993), que também observou aumento da digestibilidade da MS em carneiros, mas não notificou efeito sobre a digestibilidade da MS em vacas leiteiras, ao inocular silagem de gramínea.

Entretanto, discordam em parte dos encontrados por PHILLIP et al. (1990), os quais observaram efeitos dos inoculantes microbianos em aumentar a digestibilidade aparente da FDA, embora respostas estatisticamente significativas não tivessem sido observadas para a digestibilidade da MS e FDN. Estes autores chamam a atenção para a necessidade de estudar se possíveis diferenças no tipo da fibra entre gramíneas e leguminosas poderiam explicar diferentes respostas da digestibilidade da fibra à inoculação microbiana, uma vez que, segundo eles, é comum encontrar respostas positivas com leguminosas, mas negativas com gramíneas, fato parcialmente comprovado no presente experimento.

McALLISTER et al. (1998) não observaram efeitos dos inoculantes ( $L$. plantarum mais E. faecium ou somente L. plantarum) sobre a digestibilidade da FDN e FDA, porém notaram que a inoculação com L. plantarum aumentou a digestibilidade da MS, comparado ao grupo controle ou à inoculação com L. plantarum mais E. faecium, em silagens de alfafa. Esses autores explicaram que o aumento da digestibilidade da fibra, como observado no presente estudo, não é resultado da ação enzimática dos inoculantes sobre a fibra, uma vez que a maioria dos microrganismos contidos nos inoculantes comerciais não produzem celulases e hemicelulases. Podendo este efeito ser resultado de fatores que alteram o consumo ou a suscetibilidade da digestão da fibra no rúmen. 
MIR et al. (1995), ao trabalharem com silagens de alfafa com três teores de umidade $(18,45$ e 60\%) e inoculadas com Lactobacillus plantarum, durante três anos, não observaram efeito do inoculante sobre a digestibilidade da MS, FDN e FDA. Assim como NADEAU et al. (2000), os quais verificaram, em silagens de alfafa ou gramínea com adição de celulase mais inoculante microbiano, que não houve alteração da digestibilidade da MS e FDN, CHARMLEY et al. (1996), que não encontraram efeito do inoculante (L. casei, L. plantarum e S. lactis) sobre a digestibilidade da MS, FDN e FDA, em silagens de gramínea ou trigo, KEADY e MURPHY (1997), os quais relataram que o inoculante não alterou a digestibilidade da MS e FDN, em vacas leiteiras alimentadas com silagem de gramínea, e PATTERSON et al. (1997), ao inocularem silagem de gramínea com L. plantarum, S. faecium e P. acidilactici, percebendo que não houve efeito sobre a digestibilidade da MS e FDA.

Entretanto, para a silagem de milho, GUIM et al. (1995a) observaram que os inoculantes microbianos melhoram a digestibilidade da MS, PB, ENN, EB e o valor do NDT na silagem mais seca (37\% de MS), mas não naquelas mais úmidas (25\% de MS), embora os mesmos autores (GUIM et al., 1995b) não tivessem confirmado resultados positivos sobre a digestibilidade, quando inocularam silagem de capim elefante.

Já RODRIGUES et al. (2001b), estudando silagem de girassol inoculada ( $L$. plantarum e $S$. faecium) sobre a digestibilidade total em carneiros, verificaram aumento da digestibilidade do ENN e diminuição da digestibilidade da FB e FDA, comparado ao grupo controle, mas nenhum efeito do inoculante sobre a digestibilidade total da MS, PB, EE, FDN, amido ou NDT. Os mesmos autores (RODRIGUES et al., 2001c, d, e), avaliando a inoculação (L. plantarum e $S$. faecium) da silagem de milho ou de capimelefante e a adição de inoculante (L. plantarum, S. faecium, P. acidilactici, amilase, 
hemicelulase e celulase) na silagem de sorgo, não observaram efeito sobre as variáveis citadas acima; notaram apenas uma tendência em diminuir a digestibilidade do EE nas silagens de sorgo e milho, e em aumentar a digestibilidade do ENN na silagem de capim-elefante.

Esses autores ainda (RODRIGUES et al., 2001a), testando a digestibilidade total em carneiros alimentados com silagem de alfafa controle ou inoculada com $L$. plantarum e $P$. pentosaceus, notaram aumento da digestibilidade da MS, ENN, FDN, FDA, amido e NDT, comparado ao grupo controle, mas nenhum efeito sobre a PB, EE e FB.

Tabela 3 - Digestibilidade aparente da MS da dieta e suas frações obtidas com silagens pré-secadas de alfafa tratadas ou não com inoculante ${ }^{1}$

\begin{tabular}{|c|c|c|c|c|c|}
\hline & \multicolumn{2}{|c|}{ Tratamentos $^{2}$} & \multirow[b]{2}{*}{ Média } & \multirow[b]{2}{*}{$\mathrm{CV}$} & \multirow[b]{2}{*}{ Prob. } \\
\hline & Controle & Inoculada & & & \\
\hline$\overline{M S}$ & $74,20^{b}$ & $81,72^{\mathrm{a}}$ & 78,12 & 8,16 & 0,0005 \\
\hline PB & $74,57^{\mathrm{b}}$ & $83,08^{\mathrm{a}}$ & 79,01 & 7,84 & 0,0001 \\
\hline $\mathrm{EE}$ & $81,71^{\mathrm{b}}$ & $90,09^{\mathrm{a}}$ & 85,90 & 6,38 & 0,0006 \\
\hline ENN & $78,70^{\mathrm{b}}$ & $84,09^{\mathrm{a}}$ & 81,52 & 7,14 & 0,0086 \\
\hline FB & $61,86^{\mathrm{b}}$ & $74,83^{\mathrm{a}}$ & 68,34 & 14,80 & 0,0003 \\
\hline FDN & $57,98^{\mathrm{b}}$ & $70,01^{\mathrm{a}}$ & 63,99 & 17,03 & 0,0025 \\
\hline FDA & $63,85^{\mathrm{b}}$ & $75,17^{\mathrm{a}}$ & 69,51 & 13,42 & 0,0003 \\
\hline EB & $74,69^{\mathrm{b}}$ & $82,43^{\mathrm{a}}$ & 78,73 & 8,10 & 0,0002 \\
\hline Amido & $88,92^{\mathrm{b}}$ & $92,65^{\mathrm{a}}$ & 90,78 & 4,66 & 0,0186 \\
\hline NDT & $73,32^{\mathrm{b}}$ & $80,52^{\mathrm{a}}$ & 77,07 & 8,03 & 0,0006 \\
\hline
\end{tabular}

${ }^{1}$ MS: digestibilidade da matéria seca (\%); PB: proteína bruta (\%), EE: extrato etéreo $(\%)$, ENN: extrativos não nitrogenados (\%), FB: fibra bruta (\%), FDN: fibra em detergente neutro (\%), FDA: fibra em detergente ácido (\%), EB: energia bruta (\%), Amido (\%), NDT: nutrientes digestíveis totais (\%), CV: coeficiente de variação (\%), Prob.: probabilidades estatísticas, NS: não significativo.

${ }^{2}$ Linhas com letras sobrescritas diferentes diferem estatisticamente (5\%). 


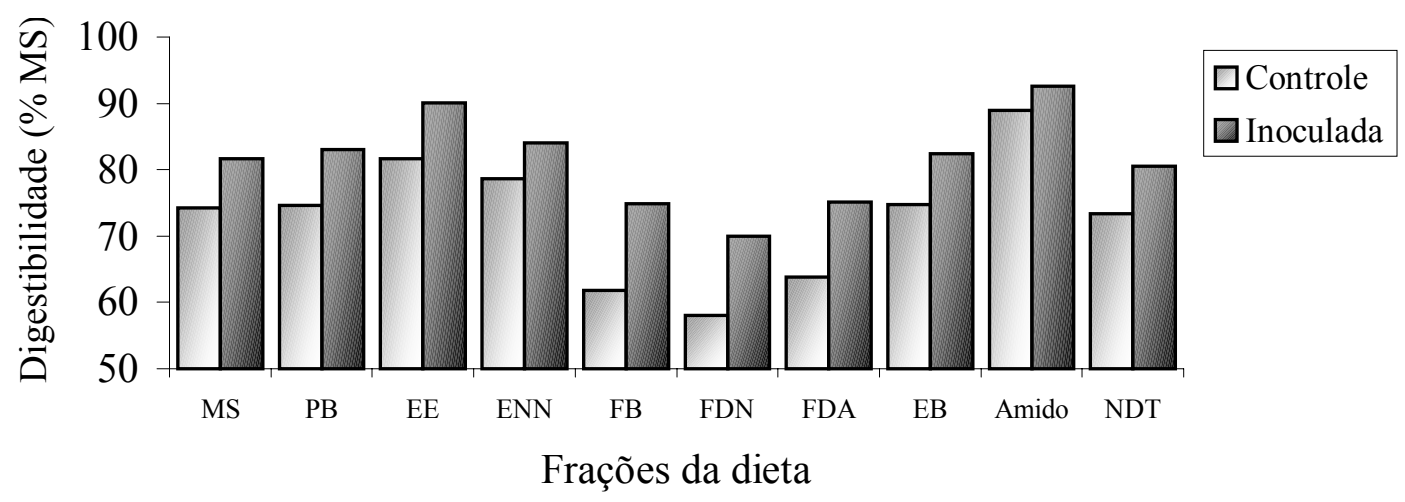

Figura 1 - Digestibilidade aparente da MS da dieta e suas frações obtidas com silagens pré-secadas de alfafa controle e inoculada.

Os dados de consumo da MS digestível e do NDT dos animais submetidos à silagem controle e inoculada encontram-se na Tabela 4. A adição de inoculante à silagem de alfafa não aumentou o consumo da MS digestível ou do NDT fossem os dados expressos em quilos/animal/dia ou em porcentagem do peso vivo.

Os dados do presente experimento concordam com os achados de RODRIGUES et al. (2001c, d, e), os quais avaliaram a inoculação das silagens de milho, de capimelefante ou de sorgo, e não observaram efeitos sobre o consumo de MS digestível ou de NDT. Entretanto, discordam desses mesmos autores (RODRIGUES et al., 2001a) ao estudarem silagem de alfafa inoculada com L. plantarum e P. pentosaceus, uma vez que encontraram aumento no consumo de MS digestível ou de NDT, expressos em porcentagem do peso vivo, em carneiros.

Outros estudos também mostraram que a inoculação não alterou o consumo de MS (KUNG et al., 1984 e STOKES, 1992), embora KENT et al. (1988) tenham observado uma tendência no aumento do consumo por vacas em lactação alimentadas 
com silagem de alfafa inoculada com L. plantarum e P. acidilactici, embora este efeito não tivesse sido estatisticamente significativo.

Entretanto, McALLISTER et al. (1998) obtiveram aumento no consumo de MS, comparando silagem inoculada com Lactobacillus plantarum e Enterococcus faecium, em relação ao grupo controle, e a revisão de MORAN e OWEN (1994) revelou aumento no consumo de MS com a inoculação das silagens de alfafa, milho ou gramínea.

MIR et al. (1995) alertam para possíveis limitações ao fazer recomendações a respeito da eficiência da inoculação baseando-se em experimentos de curta duração, uma vez que esses pesquisadores observaram aumento do consumo de silagens inoculadas de alfafa por novilhos durante um período do estudo, mas não em outros.

Pelo fato da silagem inoculada apresentar maior digestibilidade (Figura 1), esperava-se diferença no consumo de MS digestível entre os tratamentos, fato que não foi comprovado neste experimento, possivelmente pelo fornecimento de uma dieta total aos animais. NADEAU et al. (2000) relataram que silagens altamente digestíveis estão associadas com o alto consumo. Assim como a melhora na digestão dos nutrientes, provocada por mudanças na estrutura física e química da fibra, resulta em maior utilização de nutriente/energia, maior taxa de digestão e aumento no consumo (KUNG e MUCK, 1997). 
Tabela 4 - Consumo de matéria seca digestível e de NDT obtidos com silagens présecadas de alfafa tratadas ou não com inoculante ${ }^{1}$

\begin{tabular}{|c|c|c|c|c|c|}
\hline & \multicolumn{2}{|c|}{ Tratamentos } & \multirow[b]{2}{*}{ Média } & \multirow[b]{2}{*}{$\mathrm{CV}$} & \multirow[b]{2}{*}{ Prob. } \\
\hline & Controle & Inoculada & & & \\
\hline CMSD & 13,34 & 14,52 & 13,95 & 14,59 & $\mathrm{NS}$ \\
\hline CMSDPV & 2,46 & 2,67 & 2,57 & 14,69 & NS \\
\hline CNDT & 13,18 & 14,30 & 13,76 & 14,46 & NS \\
\hline CNDTPV & 2,43 & 2,63 & 2,53 & 14,56 & NS \\
\hline
\end{tabular}

CMSD: consumo de matéria seca digestível (kg/animal/dia), CMSDPV: consumo de matéria seca digestível em função do peso vivo (\%); CNDT: consumo de nutrientes digestíveis totais ( $\mathrm{kg} /$ animal $/$ dia), CNDTPV: consumo de nutrientes digestíveis totais em função do peso vivo (\%); CV: coeficiente de variação (\%), Prob: probabilidades estatísticas, NS: não significativo.

\section{Conclusões}

A adição do inoculante $\operatorname{Silobac}^{\circledR}$ à silagem pré-secada de alfafa proporcionou maior digestibilidade de nutrientes, embora não tenha proporcionado maior consumo de matéria seca digestível ou de nutrientes digestíveis totais por vacas leiteiras.

\section{Referências Bibliográficas}

ASSOCIATION OF OFFICIAL ANALYTICAL CHEMISTS - AOAC. Official methods of analysis. 10. ed. Washington, D.C.: Association of Analytical Chemistry. 1980. $1015 \mathrm{p}$.

BOLSEN, K. K.; LAYTINI, A.; HART, R. A.; NUSBACK, L.; NIROOMAND, F. Effect of commercial inoculants on fermentation of 1987 and 1988. Kansas Silage Crops. Des Moines: Pionner Hi-Bred Int., 1989. p. 1-19.

CARVAlHO, F. F. R.; QUEIROZ, A. C.; RODRIGUES, M. T.; FONTES, C. A. A. Uso de indicadores internos para estimar a digestibilidade dos nutrientes de rações para cabras em lactação alimentadas "ad libitum". Rev. Soc. Bras. Zootec., v. 21, n. 2, p. 270-278, 1992. 
CHARMLEY, E.; WINTER, K. A.; McRAE, K. B.; FILLMORE, S. A. E. Effect of inoculation on silage quality and performance of steers fed grass and cereal silages either alone or in combination. Can. J. Anim. Sci., v. 76, n. 4, p. 571-577, 1996.

GOERING, H. K.; VAN SOEST, P. J. Forage fiber analysis: apparatus, reagents, procedures and some applications. Washington. DC.: ARS-USDA, 1979. (Agric. Handbook, n. 379).

GUIM, A.; ANDRADE, P.; MALHEIROS, E. B. Efeito de inoculante microbiano sobre o consumo, degradação in situ e digestibilidade aparente de silagens de milho (Zea mays L). Rev. Soc. Bras. Zootec., v. 24, n. 6, p. 1045-1053, 1995a.

GUIM, A.; RUGGIERI, A. C.; ANDRADE, P.; MALHEIROS, E. B. Efeito de inoculante microbiano sobre consumo, degradação in situ e digestibilidade aparente das silagens de capim-elefante cv. Napier (Pennisetum purpureum Schum). Rev. Soc. Bras. Zootec., v. 24, n. 6, p. 1054-1061, 1995 b.

KEADY, T. W. J.; MURPHY, J. J. The effects of treating low dry matter herbage with a bacterial inoculant or formic acid on the intake and performance of lactating dairy cattle. Anim. Sci., v. 64, n. 1, p. 25-36, 1997.

KENT, B. A.; ARAMBEL, M. J.; WALTERS, J. L. Effect of bacterial inoculant on alfalfa haylage: ensiling characteristics and milk production response when fed to dairy cows in early lactation. J. Dairy Sci., v. 71, n. 9, p. 2457-2461, 1988.

KUNG JUNIOR, L.; GRIEVE, D. B.; THOMAS, J. W.; HUBER, J. T. Added ammonia or microbial inocula for fermentation and nitrogenous compounds of alfalfa ensiled at various percents of dry matter. J. Dairy Sci., v. 67, n. 2, p. 299-306, 1984.

KUNG JUNIOR, L.; MUCK, R. E. Animal response to silage additives. In: SILAGE: FIELD TO FEEDBUNK NORTH AMERICA CONFERENCE, 1997, Hershey. Proceedings... Hershey: NRAES, 1997. p. 200-210.

MADER, T. L.; BRITTON, R. A.; KRAUSE, V. E.; PANKASKIE, D. E. Effect of additive on alfalfa silage fermentation characteristics and feedlot performance of steers. J. Dairy Sci., v. 68, n. 7, p. 1744-1747, 1985.

MAYNE, C. S. An evaluation of an inoculant of Lactobacillus plantarum as an additive for grass silage for dairy cattle. Anim. Prod., v. 51, n. 1, p. 1-13, 1990.

MAYNE, C. S. The effect of formic acid, sulphuric acid and a bacterial inoculant on silage fermentation and the food intake and milk production of lactating dairy cows. Anim. Prod., v. 56, n. 1, p. 29-42, 1993.

McAlLISTER, T. A.; FENIUK, R.; MIR, Z.; MIR, P.; SELINGER, L. B.; CHENG, K. J. Inoculants for alfalfa silage: effects on aerobic stability, digestibility and the growth performance of feedlot steers. Livest. Prod. Sci., v. 53, n. 2, p. 171-181, 1998. 
McDONALD, P.; HENDERSON, A. R.; HERON, S. J. E. The biochemistry of silage. 2. ed. Marlow: Chalcombe Publications, 1991. 340 p.

MIR, Z.; JAN, E. Z.; ROBERTSON, J. A.; MIR, P. S.; McCARTNEY, D. H. Effects of microbial inoculant and moisture content on preservation and quality of round baled alfalfa. Can. J. Anim. Sci., v. 75, n. 1, p. 15-23, 1995.

MORAN, J. P.; OWEN, T. R. The effects of Ecosyl treated silage on milk production by lactating cows. In: NATIONAL CONFERENCE ON FORAGE QUALITY, EVALUATION AND UTILIZATION, 1994, Lincoln. Proceedings... Lincoln: University of Nebraska, 1994. p. 126.

MUCK, R. Inoculants for legume-grass silage. Focus on Forage, v. 2, n. 3, 2000. Disponível em: http://www.uwex.edu/ces/crops/uwforage/L\&GInoc.pdf. Acesso em: 21 maio 2002.

NADEAU, E. M. G.; RUSSEL, J. R.; BUXTON, D. R. Intake, digestibility and composition of orchardgrass and alfalfa silages treated with cellulase, inoculant, and formic acid fed to lambs. J. Anim. Sci., v. 78, n. 11, p. 2980-2989, 2000.

PATTERSON, D. C.; MAYNE, C. S.; GORDON, F. J.; KILPATRICK, D. J. An evaluation of an inoculant/enzyme preparation as an additive for grass silage for dairy cattle. Grass Forage Sci., v. 52, n. 3, p. 325-335, 1997.

PHILLIP, L. E.; UNDERHILL, L.; GARINO, H. Effects of treating lucerne with an inoculum of lactic acid bacteria or formic acid upon chemical changes during fermentation, and upon the nutritive value of the silage for lambs. Grass Forage Sci., v. 45, n. 3 , p. $337-344,1990$.

POLAN, C. E.; STIEVE, D. E.; GARRETT, J. L. Protein preservation and ruminal degradation of ensiled forage treated with heat, formic acid, ammonia, or microbial inoculant. J. Dairy Sci., v. 81, n. 3, p. 765-776, 1998.

RICE, D. W.; SODERLUND, S. D.; PHILLIP, I. E.; HARRISON, J. H. Effect of microbial inoculation on the digestibility of legume silages. J. Dairy Sci., v. 73, p. 195, 1990. Supplement, 1.

RODRIGUES, P. H. M.; ANDRADE, S. J. T.; ALMEIDA, L. F. S.; MEYER, P. M.; LIMA, F. R.; LUCCI, C. S. Inoculação microbiana da alfafa para ensilagem sobre a digestibilidade aparente em carneiros. Rev. Bras. Zootec., v. 30, n. 6, p. 1925-1930, 2001a.

RODRIGUES, P. H. M.; ANDRADE, S. J. T.; ALMEIDA, T. F.; MEYER, P. M.; MELOTTI, L. Valor nutritivo de silagens inoculadas com bactérias ácido-láticas. 3. Inoculação da silagem de girassol. In: REUNIÃO ANUAL DA SOCIEDADE BRASILEIRA DE ZOOTECNIA, 38., 2001, Piracicaba. Anais... Piracicaba: SBZ, 2001b. p. 915-916. 
RODRIGUES, P. H. M.; ANDRADE, S. J. T.; FERNANDES, T.; LIMA, F. R.; MELOTTI, L.; LUCCI, C. S. Valor nutritivo da silagem de capim-elefante cultivar Napier (Pennisetum purpureum, Schum) inoculada com bactérias ácido-láticas. Acta Scientiarum, v. 23, n. 4, p. 809-813, 2001c.

RODRIGUES, P. H. M.; ANDRADE, S. J. T.; RUZANTE, J. M.; LIMA, F. R.; MELOTTI, L. Valor nutritivo de silagens inoculadas com bactérias ácido-láticas. 1. Inoculação da silagem de milho. In: REUNIÃO ANUAL DA SOCIEDADE BRASILEIRA DE ZOOTECNIA, 38., 2001, Piracicaba. Anais... Piracicaba: SBZ, 2001d. p. 920-921.

RODRIGUES, P. H. M.; SENATORE, A. L.; LUCCI, C. S.; ANDRADE, S. J. T.; LIMA, F. R.; MELOTTI, L.Valor nutritivo de silagens inoculadas com bactérias ácidoláticas. 2. Inoculação da silagem de sorgo. In: REUNIÃO ANUAL DA SOCIEDADE BRASILEIRA DE ZOOTECNIA, 38., 2001, Piracicaba. Anais... Piracicaba: SBZ, 2001e. p. 918-920.

SAS Institute. SAS user's guide: statistics. 7. ed. Cary, NC: SAS Institute, 1998.

STOKES, M. R. Effects of an enzyme mixture, an inoculant, and their interaction on silage fermentation and dairy production. J. Dairy Sci., v. 75, n. 3, p. 764-773, 1992. 


\title{
CAPÍTULO V
}

\section{DESEMPENHO PRODUTIVO DE VACAS LEITEIRAS ALIMENTADAS COM SILAGEM PRÉ-SECADA DE ALFAFA ADICIONADA DE INOCULANTE MICROBIANO}

\begin{abstract}
RESUMO - Foram objetivos do presente estudo avaliar os efeitos da inoculação microbiana da silagem pré-secada de alfafa sobre o consumo de matéria seca, produção e composição do leite de vacas da raça Holandesa, multíparas, com $135 \pm 16,4$ dias de lactação, distribuídas em delineamento em reversão simples com seqüência balanceada ("cross-over") com dois períodos sucessivos. Os tratamentos corresponderam a silagem pré-secada de alfafa $(50,0 \%$ de MS e 16,5\% de PB) controle ou inoculada com o produto Silobac ${ }^{\circledR}$ (Lactobacillus plantarum e Pediococcus pentosaceus). Cada período experimental teve duração de 21 dias, sendo os cinco últimos dias destinados à coleta de dados. Não se observou efeito da inoculação sobre o CMS (inoculada $=17,8$ vs. controle $=17,8 \mathrm{~kg} /$ animal $/$ dia $)$, produção de leite corrigida para 4,0\% de gordura $(21,0$ vs. $20,4 \mathrm{~kg} /$ dia), produção de leite $(23,0$ vs. $22,4 \mathrm{~kg} / \mathrm{dia})$, porcentagem de gordura $(3,46$ vs. $3,47 \%$ ), proteína (2,96 vs. $2,93 \%)$, lactose (4,64 vs. 4,67\%), sólidos totais $(11,9$ vs. $11,9 \%$ ) e sólidos desengordurados (8,49 vs. $8,48 \%$ ), CCS (5,43 vs. $5,16 \log$ cel $\left./ 10^{3} / \mathrm{ml}\right)$, NUL (11,7 vs. $12,1 \mathrm{mg} / \mathrm{dl})$, acidez (15,9 vs. $\left.16,4^{\circ} \mathrm{D}\right)$, densidade $(1030,1$ vs. 1030,0$)$ e crioscopia $\left(-0,529\right.$ vs. $\left.-0,531^{\circ} \mathrm{H}\right)$.
\end{abstract}

Palavras-chave: bactérias láticas, bovinos, ensilagem, Medicago sativa, produção de leite 


\title{
PERFORMANCE OF LACTATING DAIRY COWS FED ALFALFA HAYLAGE ADDED WITH MICROBIAL INOCULANT
}

\begin{abstract}
The objectives of current study were to evaluate the effects of microbially inoculated alfalfa haylage on dry matter intake, milk yield and composition of Holstein cows, at $135 \pm 16.4$ days in milk. A cross-over design with two periods of sampling was used. Treatments were alfalfa haylage (50.0\% DM and $16.5 \% \mathrm{CP}$ ) control or microbially inoculated with Silobac ${ }^{\circledR}$ product (Lactobacillus plantarum and Pediococcus pentosaceus). Each experimental period extended for twenty-one days, the last five used for data collection. The inoculation did not influence DMI (inoculated = 17.8 vs. control $=17.8 \mathrm{~kg} /$ animal $/$ day $), 4 \% \mathrm{FCM}$ (21.0 vs. $20.4 \mathrm{~kg} /$ day), milk yield (23.0 vs. $22.4 \mathrm{~kg} /$ day), fat (3.46 vs. $3.47 \%$ ), protein (2.96 vs. $2.93 \%$ ), lactose (4.64 vs. $4.67 \%)$, total solids (11.9 vs. $11.9 \%)$ and fat free solids percentage (8.49 vs. $8.48 \%$ ), SCC (5.43 vs. $5.16 \log$ cell $\left./ 10^{3} / \mathrm{ml}\right)$, MUN (11.7 vs. $\left.12.1 \mathrm{mg} / \mathrm{dl}\right)$, acidity (15.9 vs. $\left.16.4^{\circ} \mathrm{D}\right)$, density $(1030.1$ vs. 1030.0$)$ and cryoscopic index $\left(-0.529\right.$ vs. $\left.-0.531^{\circ} \mathrm{H}\right)$.
\end{abstract}

Keywords: cattle, ensiling, lactic acid bacteria, Medicago sativa, milk yield 


\section{Introdução}

Para produzir uma silagem de qualidade é necessário manter o meio anaeróbio, substrato adequado para as bactérias produtoras de ácido lático e uma população dessas bactérias em quantidade suficiente para que a fermentação ocorra (MUCK, 1988).

Assim, para se dominar a fase inicial do processo fermentativo da silagem tem sido observada uma tendência do uso de inoculantes contendo bactérias ácido láticas (BOLSEN et al., 1989). As mudanças esperadas com a inoculação incluem um rápido declínio no $\mathrm{pH}$, uma diminuição na concentração de nitrogênio amoniacal, decréscimo nos níveis de acetato e butirato e um aumento no conteúdo de ácido lático (KUNG et al., 1984).

Contudo, os efeitos da inoculação microbiana na silagem de alfafa são bastante variáveis (MUCK, 1988). Melhora das características fermentativas da silagem (GORDON, 1989 e FREEDEN et al., 1991) e diminuição das perdas de matéria seca (RICE et al., 1990), observadas com a inoculação, nem sempre resultam em melhoria do valor nutricional, consumo voluntário ou desempenho animal (STOKES, 1992).

Entretanto alguns estudos demonstraram que o uso de aditivos na ensilagem promove melhora no consumo do alimento, na produção de leite (MAYNE e STEEN, 1993), na fermentação da silagem, na digestibilidade da dieta e no desempenho animal (HENDERSON et al., 1987; APPLETON e DONE, 1987; ROOKE et al., 1988; ANDERSON et al., 1989).

O presente estudo teve como objetivo avaliar a influência da inoculação microbiana da silagem pré-secada de alfafa sobre o consumo de matéria seca, a produção e a composição do leite de vacas leiteiras. 


\section{Material e Métodos}

O trabalho foi conduzido nas dependências do Departamento de Nutrição e Produção Animal da Faculdade de Medicina Veterinária e Zootecnia da Universidade de São Paulo (Campus de Pirassununga).

A cultura de alfafa foi cortada em dezembro de 2000, quando em estádio do meio do florescimento. Após colhido e pré-seco por quatro horas, o material original foi acondicionado em fardos com aproximadamente $150 \mathrm{~cm}$ de altura e $150 \mathrm{~cm}$ de diâmetro (capacidade de 600 quilos), revestidos com película de PVC branca. Os silos foram divididos em dois tratamentos, um controle e outro com adição do inoculante comercial Silobac $^{\circledR}$ (Chr. Hansen Indústria e Comércio Ltda.), segundo as recomendações do fabricante. De acordo com essas recomendações, o produto fornece 1,0 x $10^{5}$ unidades formadoras de colônia (Lactobacillus plantarum e Pediococcus pentosaceus) por grama de forragem. O inoculante comercial Silobac ${ }^{\circledR}$ foi escolhido em função de melhores resultados obtidos ao avaliar os inoculantes Sil-All ${ }^{\circledR}$ (Alltech do Brasil Agroindustrial Ltda.), Pioneer $1174^{\circledR}$ (Pioneer Sementes Ltda.) e Silobac ${ }^{\circledR}$ em ensaios fermentativos com cultura de alfafa ensilada em silos experimentais (resultados não publicados). A alfafa foi escolhida por ser a cultura que apresentou as maiores respostas à inoculação quando comparada às silagens de milho, sorgo, girassol ou capim elefante.

Aproximadamente $600 \mathrm{~kg}$ de massa úmida foram colocadas em cada silo, correspondendo a uma compactação de aproximadamente $230 \mathrm{~kg}$ de silagem $/ \mathrm{m}^{3}$. Os silos foram mantidos fechados por 60 dias expostos às intempéries.

Foram utilizadas 12 vacas Holandesas, com $135 \pm$ 16,4 dias de lactação, alojadas em baias individuais presas por corrente (sistema tie-stall). $\mathrm{O}$ delineamento 
experimental foi de reversão simples com seqüência balanceada (“cross-over") com dois períodos de coletas, adicionados das covariáveis produção de leite e dias em lactação observados ao início do experimento, e os tratamentos compostos pelas silagens controle ou inoculada na proporção de $50 \%$ concentrados e $50 \%$ de volumosos na dieta (Tabela 1 e 2). A ração foi fornecida em duas refeições, às 8:00 e 16:00 horas, sendo a silagem oferecida juntamente com o concentrado, permitindo-se $15 \%$ de sobras.

Tabela 1 - Composição bromatológica das silagens pré-secadas de alfafa controle e inoculada (porcentagem com base na MS)

\begin{tabular}{lcccccccccc}
\hline Silagem & MS & PB & EE & MM & FB & FDN & FDA & Amido & Ca & P \\
\hline Controle & 51,96 & 16,58 & 1,76 & 11,44 & 30,82 & 47,72 & 40,34 & 1,36 & 0,83 & 0,31 \\
Inoculada & 47,48 & 16,32 & 2,00 & 11,85 & 31,34 & 46,10 & 40,93 & 0,92 & 0,79 & 0,33 \\
\hline
\end{tabular}

A Tabela 2 mostra as rações utilizadas e os resultados das análises bromatológicas das mesmas. 
Tabela 2 - Proporções de ingredientes utilizados e composição bromatológica das rações, com base na matéria seca

\begin{tabular}{lcc}
\hline \multirow{2}{*}{ Ingredientes (\%) } & \multicolumn{2}{c}{ Tratamentos } \\
\cline { 2 - 3 } Silagem de alfafa & Controle & Inoculada \\
Silagem de alfafa inoculada & 50,0 & - \\
Grãos de milho moído & - & 50,0 \\
Grãos de soja extrusados & 40,5 & 40,5 \\
Calcário calcítico & 7,5 & 7,5 \\
Sal branco & 0,10 & 0,10 \\
Mistura mineral ${ }^{1}$ & 0,63 & 0,63 \\
& 1,21 & 1,21 \\
\hline \multicolumn{1}{c}{ Composição } & 100,00 & 100,00 \\
\hline MS (\%) & & \\
PB (\%) & 65,4 & 61,7 \\
Proteína degradável (\%) & 15,8 & 15,7 \\
Proteína não degradável (\%) & 10,7 & 10,6 \\
FDA (\%) & 5,1 & 5,1 \\
FDN (\%) & 22,3 & 22,6 \\
EE (\%) & 28,8 & 28,0 \\
Energia Líq. Lact. (Mcal/kg) & 2,7 & 2,8 \\
Ca (\%) & 1,53 & 1,53 \\
P (\%) & 0,70 & 0,70 \\
\hline Composic̃a por kg de & 0,40 & 0,50 \\
\hline
\end{tabular}

${ }^{\mathrm{T} C o m p o s i c ̧ a ̃ o ~ p o r ~ k g ~ d e ~ m i s t u r a ~ m i n e r a l: ~} 180 \mathrm{~g} \mathrm{Ca}, 90 \mathrm{~g} \mathrm{P}, 20 \mathrm{~g} \mathrm{Mg}$, $20 \mathrm{~g} \mathrm{~S}, 100 \mathrm{~g} \mathrm{Na}, 3.000 \mathrm{mg} \mathrm{Zn}, 1.000 \mathrm{mg} \mathrm{Cu}, 1.250 \mathrm{mg} \mathrm{Mn}, 2.000 \mathrm{mg}$ Fe, 200mg Co, 90mg I, 36mg Se, 900mg F (máximo).

O período experimental teve duração total de 42 dias, sendo 21 dias para cada período, dos quais os primeiros 16 dias foram destinados à adaptação dos animais às dietas, nos cinco últimos dias foram realizadas mensurações do consumo e nos três últimos, coleta de leite das duas ordenhas. Para comporem uma amostra final, o leite foi amostrado duas vezes ao dia, durante as ordenhas.

As análises dos componentes do leite (gordura, proteína, lactose e sólidos totais) foram realizadas por infravermelho, através do equipamento Bentley $2000^{\circledR}$ (Bentley Instruments, Chaska, MN). A determinação da densidade do leite foi realizada por termolactodensímetro, a acidez pelo método de Dornic e o índice crioscópico com a 
utilização do aparelho Crioscópio Eletrônico Digital ITR-MK540, segundo MINISTÉRIO DA AGRICULTURA (1981). A determinação da contagem de células somáticas no leite (CCS) foi realizada por citometria de fluxo, utilizando o aparelho Somacount $300^{\circledR}$ (Bentley Instruments, Chaska, MN). A determinação dos níveis de nitrogênio uréico no leite (NUL) foi realizada por colorimetria enzimática, através do equipamento ChemSpeck $150^{\circledR}$ (Bentley Instruments, Chaska, MN).

As análises bromatológicas de matéria seca (MS), proteína bruta (PB), extrato etéreo $(\mathrm{EE})$, fibra bruta $(\mathrm{FB})$, matéria mineral $(\mathrm{MM})$, amido, cálcio $(\mathrm{Ca})$ e fósforo $(\mathrm{P})$ dos ingredientes da dieta foram realizadas segundo AOAC (1980) e de fibra em detergente neutro (FDN) e fibra em detergente ácido (FDA) segundo GOERING e VAN SOEST (1979). Para a análise de FDN foi omitido o sulfito de sódio, mas adicionada a $\alpha$-amilase.

Os resultados foram analisados através do programa computacional Statistical Analysis System (SAS Institute Inc., 1998). Os dados foram submetidos à análise de variância pelo procedimento GLM (PROC GLM), que separaram como causas de variação o efeito de tratamento, efeito de período e as covariáveis produção de leite e dias em lactação ao início do experimento. Foi utilizado o nível de significância de 5\% para todos os testes realizados.

\section{Resultados e Discussão}

Os dados de consumo dos animais submetidos à silagem controle e inoculada encontram-se na Tabela 3. A adição de inoculante à silagem pré-secada de alfafa não aumentou o consumo de matéria seca (CMS) fossem os dados expressos em 
quilos/animal/dia, em porcentagem do peso vivo ou porcentagem do peso metabólico. De forma geral, o CMS, que em média foi de 3,3\% do peso vivo, mostrou-se dentro do esperado, uma vez que a fermentação das silagens controle ou inoculada apresentou-se aparentemente normal, sem fermentações indesejáveis.

Semelhantemente ao aqui observado, GRIEVE et al. (1982); KUNG et al. (1984); MADER et al. (1985); KENT et al. (1988) e PHILLIP et al. (1990) não observaram resultados positivos da inoculação sobre o consumo de silagem de alfafa. Enquanto KENT et al. (1988) perceberam uma tendência no aumento do consumo por vacas em lactação alimentadas com silagem de alfafa inoculada com $L$. plantarum e $P$. acidilactici, mas este efeito não foi estatisticamente significativo.

Já McALLISTER et al. (1998) observaram efeitos dos inoculantes microbianos em aumentar o CMS da silagem de alfafa por ovinos. O mesmo observaram PATTERSON et al. (1996), utilizando inoculante microbiano em silagem de gramínea, e PATTERSON et al. (1997), adicionando ácido fórmico em silagem de gramínea para bovinos.

Tabela 3 - Consumo de matéria seca obtido com silagens pré-secadas de alfafa submetidas ou não à aplicação de inoculante ${ }^{1}$

\begin{tabular}{|c|c|c|c|c|c|}
\hline & \multicolumn{2}{|c|}{ Tratamentos } & \multirow[b]{2}{*}{ Média } & \multirow[b]{2}{*}{$\mathrm{CV}$} & \multirow[b]{2}{*}{ Prob. } \\
\hline & Controle & Inoculada & & & \\
\hline CMS & 17,82 & 17,84 & 17,83 & 13,46 & NS \\
\hline CMSPV & 3,30 & 3,28 & 3,29 & 14,40 & NS \\
\hline CMSPV $^{0,75}$ & 159,08 & 158,47 & 158,47 & 13,75 & NS \\
\hline
\end{tabular}

${ }^{\mathrm{T}} \mathrm{CMS}$ : consumo de matéria seca (kg/animal/dia), CMSPV: consumo de matéria seca em função do peso vivo (\%), $\mathrm{CMSPV}^{0,75}$ : consumo de matéria seca em gramas por $\mathrm{kg}$ de peso vivo metabólico ( $\mathrm{g} / \mathrm{kg}$ de $\left.\mathrm{PV}^{0,75}\right), \mathrm{CV}$ : coeficiente de variação (\%), Prob: probabilidades estatísticas, NS: não significativo. 
Os resultados da produção e composição do leite em resposta à inoculação microbiana da silagem pré-secada de alfafa encontram-se na Tabela 4.

A inoculação da silagem pré-secada de alfafa não aumentou a produção de leite, do leite corrigido para $4,0 \%$ de gordura e a produção e composição de gordura, proteína, lactose, sólidos totais e sólidos desengordurados (Figura 1 e 2), o que está de acordo com os estudos realizados por CHAMBERLAIN et al. (1987), que não observaram efeito algum da inoculação, FREDEEN et al. (1991) e MAYNE (1993), quando avaliaram a inoculação de silagens de gramíneas, e KUNG et al. (1993), com a inoculação de silagem de milho. Tais resultados concordam também com os achados de KENT et al. (1989) que, utilizando silagem de alfafa pré-secada e inoculada, não notaram efeito sobre a produção de leite, LCG 3,5\% e produção e composição de gordura, proteína e lactose, e os estudos de PATTERSON et al. (1997) e GASIOR e BRZOSKA (2000), autores que também não perceberam aumento na produção e composição do leite de vacas, quando utilizaram silagens de gramíneas com ácido fórmico ou inoculante microbiano.

Embora MARTINSSON (1991) tenha demonstrado um aumento significativo na produção de leite de vacas tratadas com silagem de gramínea pré-secada e inoculada, CHAMBERLAIN et al. (1992) observaram aumento significativo na produção e composição da gordura no leite, MAYNE (1990) notaram aumento na proteína do leite, mas não na gordura, e KUNG et al. (1987) perceberam aumento na produção de leite no primeiro ano, mas não no ano seguinte, com a inoculação da silagem de alfafa. A revisão de MORAN e OWEN (1994) revelou, ainda, que a inoculação das silagens de alfafa, milho ou gramínea aumentou a produção de leite. 
Entretanto, CHEN et al. (1994), utilizando silagem de gramíneas e trevo inoculada com enzimas, perceberam diminuição na produção de leite, de proteína e de sólidos desengordurados, mas não observaram efeito sobre a produção de leite corrigida para 3,5\% de gordura, bem como para produção e composição de gordura e composição de proteína, enquanto PATTERSON et al. (1996) observaram que a inoculação da silagem de gramínea aumentou a produção de gordura, porém reduziu a mesma com a utilização da silagem pré-secada. Já para a composição de gordura, proteína e lactose do leite, nenhum efeito foi demonstrado.

Alguns estudos observaram efeito na produção de leite com a inoculação de várias forragens na ensilagem, incluindo a alfafa (COLENBRANDER et al. 1988) e o milho (WOHLT, 1989).

A proteína da alfafa está sujeita a sofrer uma extensa degradação durante o processo de ensilagem, podendo estar na forma de nitrogênio não protéico (NNP) cerca de 75 a $87 \%$ do total de nitrogênio presente na silagem (MUCK, 1987). Estudos mostraram que o excesso de degradação ruminal resulta em um ineficiente aproveitamento da proteína da alfafa, o que pode diminuir o rendimento leiteiro e a própria proteína do leite (BRODERICK, 1985).

Segundo MUCK e KUNG (1997), as bactérias ácido láticas (ácido-tolerantes) epfíticas são as que mais competem com o inoculante, mas se a adição deste último corresponder a pelo menos um décimo da população dessas bactérias, será capaz de sobrepo-las e melhorar a fermentação. Entretanto, para melhorar o desempenho animal, como por exemplo a produção de leite, SATTER et al. (1991) perceberam com a inoculação da silagem de alfafa, que é necessário que a adição de inoculante seja, pelo 
menos, 10 vezes maior que a população de bactérias ácido-tolerantes da forragem inicial.

É possível que a qualidade da silagem controle obtida no presente experimento já estivesse boa o suficiente para permitir melhoras com a inoculação. Embora não se disponha da contagem de bactérias epfíticas inicial no presente experimento, também é possível que a adição de bactérias ácido láticas não tenha sido grande o suficiente para permitir melhoras na qualidade da silagem.

Tabela 4 - Efeitos da inoculação microbiana da silagem pré-secada de alfafa sobre a produção e composição do leite ${ }^{1}$

\begin{tabular}{lccccc}
\hline & \multicolumn{2}{c}{ Tratamentos } & & & \\
\cline { 2 - 3 } & Controle & Inoculada & Média & CV & Prob. \\
\hline Produção de leite & 22,37 & 22,98 & 22,69 & 11,97 & NS \\
LCG 4,0\% & 20,41 & 21,00 & 20,69 & 13,99 & NS \\
Gordura & 3,47 & 3,46 & 3,46 & 10,40 & NS \\
Produção de gordura & 0,769 & 0,781 & 0,774 & 12,28 & NS \\
Proteína & 2,93 & 2,96 & 2,95 & 11,15 & NS \\
Produção de proteína & 0,649 & 0,674 & 0,661 & 14,60 & NS \\
Lactose & 4,67 & 4,64 & 4,66 & 5,54 & NS \\
Produção de lactose & 1,049 & 1,073 & 1,062 & 21,64 & NS \\
Sólidos totais & 11,94 & 11,88 & 11,91 & 5,22 & NS \\
Prod. sólidos totais & 2,65 & 2,74 & 2,69 & 15,84 & NS \\
Sólidos desengor. & 8,48 & 8,49 & 8,49 & 3,85 & NS \\
Prod. sólidos desengor. & 1,89 & 1,95 & 1,92 & 17,86 & NS \\
\hline
\end{tabular}

${ }^{1}$ Produção de leite (kg/dia), LCG 4,0\%: produção de leite corrida para 4\% de gordura $(\mathrm{kg} / \mathrm{dia})$, Gordura $(\%)$, Produção de gordura $(\mathrm{kg} / \mathrm{dia})$, Proteína $(\%)$, Produção de proteína (kg/dia), Lactose (\%), Produção de lactose (kg/dia), Sólidos totais (\%), Prod. sólidos totais: produção de sólidos totais ( $\mathrm{kg} / \mathrm{dia})$, Sólidos desengor.: sólidos desengordurados (\%), Prod. sólidos desengor.: produção de sólidos desengordurados (kg/dia), CV: coeficiente de variação (\%), Prob: probabilidades estatísticas, NS: não significativo. 


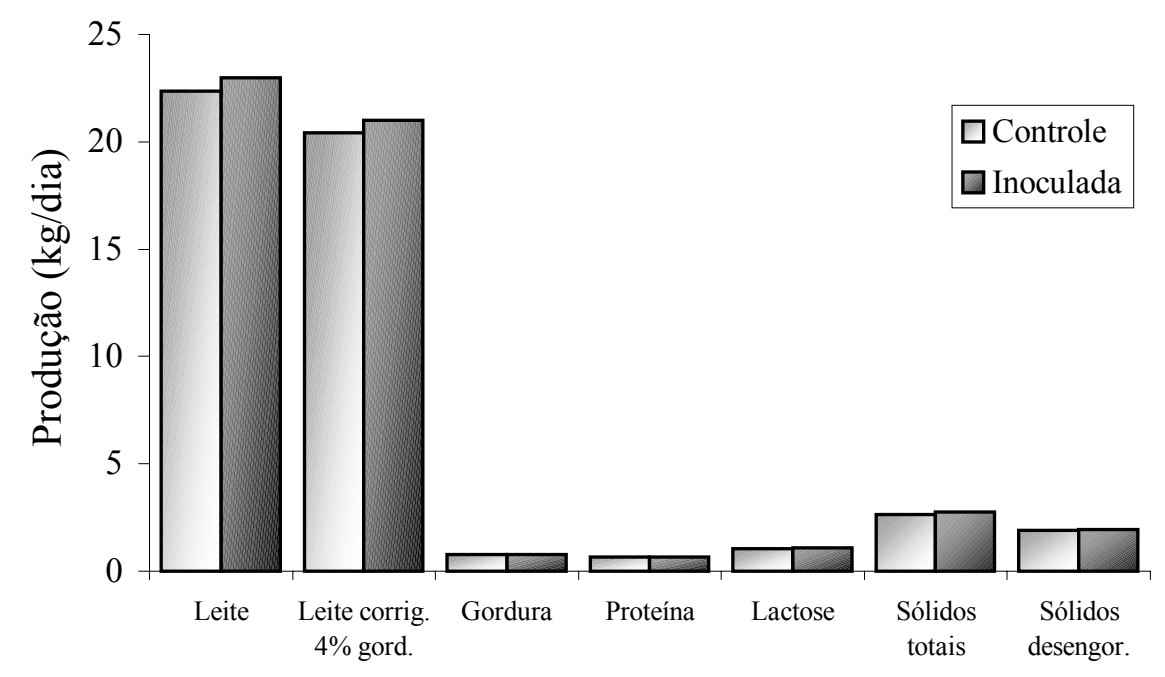

Figura 1 - Produção de leite e de seus componentes por vacas alimentadas com silagens pré-secadas de alfafa controle ou inoculada.

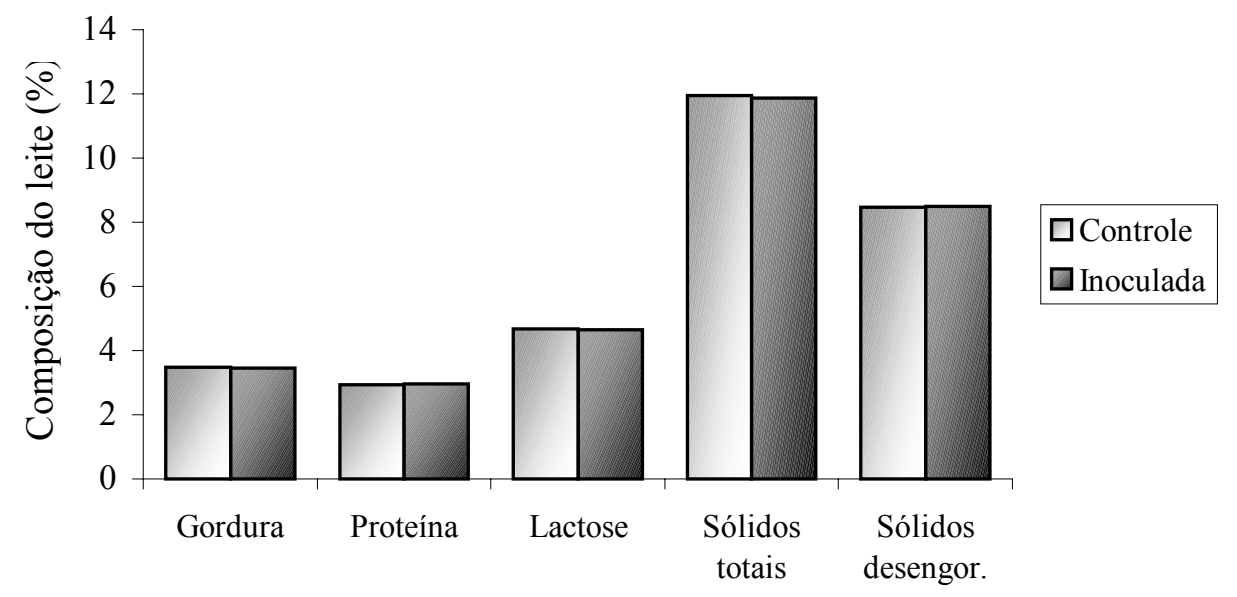

Figura 2 - Composição do leite de vacas alimentadas com silagens pré-secadas de alfafa controle ou inoculada. 
Os resultados das características físico-químicas do leite em resposta à inoculação microbiana da silagem pré-secada de alfafa encontram-se na Tabela 5.

No presente estudo, também se observou ausência de efeitos da inoculação sobre a CCS, o NUL, a acidez, a densidade e a crioscopia do leite, embora dados semelhantes obtidos com a inoculação não estejam disponíveis na literatura.

Tabela 5 - Efeitos da inoculação microbiana da silagem pré-secada de alfafa sobre a CCS, NUL e características físico-químicas do leite ${ }^{1}$

\begin{tabular}{lccccc}
\hline & \multicolumn{2}{c}{ Tratamentos } & & & \\
\cline { 2 - 3 } & Controle & Inoculada & Média & CV & Prob. \\
\hline CCS & 5,16 & 5,43 & 5,29 & 30,41 & NS \\
NUL & 12,07 & 11,65 & 11,87 & 16,87 & NS \\
Acidez & 16,35 & 15,89 & 16,14 & 8,40 & NS \\
Densidade & 1030,04 & 1030,08 & 1030,06 & 0,12 & NS \\
Crioscopia & $-0,531$ & $-0,529$ & $-0,530$ & $-0,748$ & NS \\
\hline
\end{tabular}

${ }^{1}$ CCS: contagem de células somáticas (log cel $\left./ 10^{3} / \mathrm{ml}\right)$, NUL: nitrogênio uréico no leite $(\mathrm{mg} / \mathrm{dl})$, Acidez $\left({ }^{\circ} \mathrm{D}\right)$, Densidade, Crioscopia $\left({ }^{\circ} \mathrm{H}\right), \mathrm{CV}$ : coeficiente de variação $(\%)$, Prob: probabilidades estatísticas, NS: não significativo.

\section{Conclusões}

O uso do inoculante microbiano Silobac ${ }^{\circledR}$ na silagem pré-secada de alfafa não mostrou efeito diferenciado na produção, composição e qualidade do leite, dentro das condições do presente trabalho. 


\section{Referências Bibliográficas}

ANDERSON, R.; GRACEY, H. I.; KENNEDY, S. J.; UNSWORTH, E. F.; STEEN, R. W. J. Evaluation studies in the development of a commercial bacterial inoculant as an additive for grass silage. 1. Using pilot scale tower silos. Grass Forage Sci., v. 44, n. 4, p. 361-369, 1989.

APPLETON, M.; DONE, D. The effect of an inoculant silage additive on the fermentation of grass and animal performance. In: SILAGE CONFERENCE, 8., 1987, Hurley. Proceedings... Hurley: Institute for Grassland and Animal Production. 1987. p.15-16.

ASSOCIATION OF OFFICIAL ANALYTICAL CHEMISTS - AOAC. Official methods of analysis. 10. ed. Washington, D.C.: Association of Analytical Chemistry. 1980. $1015 \mathrm{p}$.

BOLSEN, K. K.; LAYTINI, A.; HART, R. A.; NUSBACK, L.; NIROOMAND, F. Effect of commercial inoculants on fermentation of 1987 and 1988. Kansas Silage Crops. Des Moines: Pionner Hi-Bred Int., 1989. p. 1-19.

BRASIL. Ministério da Agricultura. Secretaria Nacional de Defesa Agropecuária. Laboratório Nacional de Referência Animal - LANARA. Métodos analíticos oficiais para controle de produtos de origem animal e seus ingredientes: métodos físicos e químicos. Brasília: LANARA, 1981. v. 2.

BRODERICK, G. A. Alfalfa silage or hay versus corn silage as the sole forage for lactating dairy cows. J. Dairy Sci., v. 68, n. 12, p. 3262-3271, 1985.

CHAMBERLAIN, D. G.; MARTIN, P. A.; ROBERTSON, S.; HUNTER, E. A. Effects of the type of additive and the type of supplement on the utilization of grass silage for milk production in dairy cows. Grass Forage Sci., v. 47, n. 4, p. 391-399, 1992.

CHAMBERLAIN, D. G.; THOMAS, P. C.; ROBERTSON, S. The effect of formic acid, bacterial inoculants and enzyme additives on feed intake and milk production in cows given silage of high or moderate digestibility with two levels of supplementary concentrates. In: SILAGE CONFERENCE, 8., 1987, Hurley. Proceedings... Hurley: Institute for Grassland and Animal Production. 1987, p.31-32.

CHEN, J.; STOKES, M. R.; WALLACE, C. R. Effects of enzyme-inoculant systems on preservation and nutritive value of haycrop and corn silages. J. Dairy Sci., v. 77, n. 2, p. 501-512, 1994.

COLENBRANDER, V. F.; GRANT, R. J.; SCHAAF, G. Milk production and feed intake of dairy cows fed Lactobacillus inoculated alfalfa silage. Appl. Agric. Res., v. 3, n. 1, p. 55-59, 1988. 
FREDEEN, A. H.; McQUEEN, R. E.; BROWNING, D. A. Effects of enzymes and nutrients in a bacterial inoculant on quality of timothy or alfalfa silage and dairy cow performance. Can. J. Anim. Sci., v. 71, n. 3, p. 781-791, 1991.

GASIOR, R.; BRZOSKA, F. The effects of wilting and additives on silage quality, protein degradation in the silo and in the rumen, and dairy cattle productivity. Annals of Animal Science. Roczniki Naukowe Zootechniki, v. 27, n. 4, p. 129-141, 2000.

GOERING, H. K.; VAN SOEST, P. J. Forage fiber analysis: apparatus, reagents, procedures and some applications. Washington. DC.: ARS-USDA, 1979. (Agric. Handbook, n. 379).

GORDON, F. J. An evaluation through lactating cattle of a bacterial inoculant as an additive for grass silage. Grass Forage Sci., v. 44, n. 2, p. 169-179, 1989.

GRIEVE, D. B.; AHRENS, K. R.; THOMAS, J. W.; HUBER, J. T. Production of lactating cows and growing steers fed alfalfa haylage treated with ammonia or a microbial inoculant. J. Dairy Sci., v. 65, p. 143, 1982. Supplement, 1.

HENDERSON, A. R.; ANDERSON, D. H.; NEILSON, D. R.; HUNTER, E. A. The effect of a commercial inoculant and Add-F applied at two levels on the chemical characteristics and utilization of ryegrass silage over two seasons. In: SILAGE CONFERENCE, 8., 1987, Hurley. Proceedings... Hurley: Institute for Grassland and Animal Production. 1987. p. 13-14.

KENT, B. A.; ARAMBEL, M. J.; WALTERS, J. L. Effect of bacterial inoculant on alfalfa haylage: ensiling characteristics and milk production response when fed to dairy cows in early lactation. J. Dairy Sci., v. 71, n. 9, p. 2457-2461, 1988.

KENT, B. A.; ARAMBEL, M. J.; WINSRYG, M. D.; WALTERS, J. L. Microbial inoculation of alfalfa haylage: Ensiling characteristics and milk production response when fed to early lactation dairy cows. J. Dairy Sci., v. 72, n. 9, p. 2325-2330, 1989.

KUNG JUNIOR, L.; CHEN, J. H.; KRECK, E. M.; KNUTSEN, K. Effect of microbial inoculants on the nutritive value of corn silage for lactating dairy cows. J. Dairy Sci., v. 76, n. 12, p. 3763-3770, 1993.

KUNG JUNIOR, L.; GRIEVE, D. B.; THOMAS, J. W.; HUBER, J. T. Added ammonia or microbial inocula for fermentation and nitrogenous compounds of alfalfa ensiled at various percents of dry matter. J. Dairy Sci., v. 67, n. 2, p. 299-306, 1984.

KUNG JUNIOR, L.; SATTER, L. D.; JONES, B. A.; GENIN, K. W.; SUDOMA, A. L.; ENDERS JUNIOR, G. L.; KIM, H. S. Microbial inoculation of low moisture alfalfa silage. J. Dairy Sci., v. 70, n. 10, p. 2069-2077, 1987.

MADER, T. L.; BRITTON, R. A.; KRAUSE, V. E.; PANKASKIE, D. E. Effect of additive on alfalfa silage fermentation characteristics and feedlot performance of steers. J. Dairy Sci., v. 68, n. 7, p. 1744-1747, 1985. 
MARTINSSON, K. A comparison between formic acid and an inoculant for the preservation of grass silage for dairy cows. Swe. J. Agric. Res., v. 21, n. 3, p. 121-130, 1991.

MAYNE, C. S. An evaluation of an inoculant of Lactobacillus plantarum as an additive for grass silage for dairy cattle. Anim. Prod., v. 51, n. 1, p. 1-13, 1990.

MAYNE, C. S. The effect of formic acid, sulphuric acid and a bacterial inoculant on silage fermentation and the food intake and milk production of lactating dairy cows. Anim. Prod., v. 56, n. 1, p. 29-42, 1993.

MAYNE, C. S.; STEEN, R. W. J. A review of animal production responses to formic acid and inoculant treatment of grass silage in trials at the Agricultural Research Institute of Northern Ireland. In: INTERNATIONAL CONFERENCE ON SILAGE RESEARCH, 10., 1993, Dublin. Proceedings... Dublin: Silage research 1993. p. 178179.

McALLISTER, T. A.; FENIUK, R.; MIR, Z.; MIR, P.; SELINGER, L. B.; CHENG, K. J. Inoculants for alfalfa silage: effects on aerobic stability, digestibility and the growth performance of feedlot steers. Livest. Prod. Sci., v. 53, n. 2, p. 171-181, 1998.

MORAN, J. P.; OWEN, T. R. The effects of Ecosyl treated silage on milk production by lactating cows. In: NATIONAL CONFERENCE ON FORAGE QUALITY, EVAlUATION AND UTILIZATION, 1994, Lincoln. Proceedings... Lincoln: University of Nebraska, 1994. p. 126.

MUCK, R. E. Dry matter level effects on alfalfa silage quality. I. Nitrogen transformations. Trans. Am. Soc. Agric. Eng., v. 30, n. 1, p. 7-14, 1987.

MUCK, R. E. Factors influencing silage quality and their implications for management. J. Dairy Sci., v. 71, n. 11, p. 2992-3002, 1988.

MUCK, R. E.; KUNG JUNIOR, L. Effects of silage additives on ensiling. In: SILAGE: FIELD TO FEEDBUNK NORTH AMERICA CONFERENCE, 1997, Hershey. Proceedings... Hershey: NRAES, 1997. p. 187-199.

PATTERSON, D. C.; MAYNE, C. S.; GORDON, F. J.; KILPATRICK, D. J. An evaluation of an inoculant/enzyme preparation as an additive for grass silage for dairy cattle. Grass Forage Sci., v. 52, n. 3, p. 325-335, 1997.

PATTERSON, D. C.; YAN, T.; GORDON, F. J. The effects of wilting of grass prior to ensiling on the response to bacterial inoculation. 2. Intake and performance by dairy cattle over three harvests. Anim. Sci., v. 62, n. 3, p. 419-429, 1996.

PHILLIP, L. E.; UNDERHILL, L.; GARINO, H. Effects of treating lucerne with an inoculum of lactic acid bacteria or formic acid upon chemical changes during fermentation, and upon the nutritive value of the silage for lambs. Grass Forage Sci., v. 45, n. 3, p. 337-344, 1990. 
RICE, D. W.; SODERLUND, S. D.; PHILlIP, I. E.; HARRISON, J. H. Effect of microbial inoculation on the digestibility of legume silages. J. Dairy Sci., v. 73, p. 195, 1990. Supplement, 1.

ROOKE, J. A.; MAYA, F. M.; ARNOLD, J. A.; ARMSTRONG, D. G. The chemical composition and nutritive value of grass silages prepared with no additive or with the application of additives containing either Lactobacillus plantarum or formic acid. Grass Forage Sci., v. 43, n. 1, p. 87-95, 1988.

SAS Institute. SAS user's guide: statistics. 7. ed. Cary, NC: SAS Institute, 1998.

SATTER, L. D.; MUCK, R. E.; JONES, B. A.; DHIMAN, T. R., WOODFORD, J. A.; WACEK, C. M. Efficacy of bacterial inoculants for lucerne silage. In: FORAGE CONSERVATION TOWARDS 2000, 123., 1991, Braunschweig. Proceedings... Braunschweig: Landbauforschung Voelkenrode. Sonderheft, 1991. p. 342-343.

STOKES, M. R. Effects of an enzyme mixture, an inoculant, and their interaction on silage fermentation and dairy production. J. Dairy Sci., v. 75, n. 3, p. 764-773, 1992.

WOHLT, J. E. Use of a silage inoculant to improve feeding stability and intake of a corn silage-grain diet. J. Dairy Sci., v. 72, n. 2, p. 545-551, 1989. 


\section{CAPÍTULO VI}

\section{CONSIDERAÇÕES FINAIS}

No presente experimento, a cultura de alfafa e o inoculante Silobac ${ }^{\circledR}$ (Lactobacillus plantarum e Pediococcus pentosaceus) foram escolhidos por apresentarem melhores resultados em experimentos realizados anteriormente pelo mesmo grupo de pesquisa, onde foram avaliadas cinco espécies forrageiras (alfafa, capim elefante, girassol, milho e sorgo), ensiladas com três tipos de inoculantes (Pioneer $1174^{\circledR}$, Sil-All $^{\circledR}$ e Silobac ${ }^{\circledR}$ ) cada uma.

Embora não tivesse alterado as concentrações de etanol e dos ácidos lático, butírico e propiônico, o inoculante elevou a concentração de ácido acético, o que pode ter contribuído para a redução do bolor das silagens, principalmente na parte mais externa.

A redução de bolor nas silagens inoculadas, em função da fermentação ocorrida e dos produtos gerados por ela, pode ter melhorado a digestibilidade desta, embora a diluição da silagem inoculada na dieta total, consumo de matéria seca equivalente e outros tamponamentos ocorridos na vaca, não permitissem observar melhora sobre o desempenho produtivo dos animais.

Dentro das condições do presente experimento, onde ambas as silagens apresentaram alto teor de matéria seca devido a pré-secagem, a utilização do inoculante não apresentou-se vantajosa para os níveis de fermentação e desempenho produtivo, uma vez que não houve diferença significativa entre os tratamentos, exceto para a digestibilidade, que mostrou-se superior na silagem inoculada. Provavelmente, o uso da 
inoculação em material com maior teor de umidade favorecesse a eficiência da sua utilização.

Mais trabalhos devem ser desenvolvidos, utilizando-se outros inoculantes e outras espécies forrageiras para a ensilagem, uma vez que a maior parte dos dados disponíveis foram obtidos em países desenvolvidos, onde o clima e as condições de manejo dos animais são diferentes dos encontrados no Brasil. 